\title{
ANÁLISE DAS POSSIBILIDADES DE UTILIZAÇÃO DE SISTEMAS SUPERVISÓRIOS NO PLANEJAMENTO E CONTROLE DE PRODUÇÃO
}

\author{
Gustavo Santos Junqueira
}

\author{
Dissertação apresentada à Escola de \\ Engenharia de São Carlos da \\ Universidade de São Paulo, como parte \\ dos requisitos para obtenção do título \\ de Mestre em Engenharia de Produção
}

ORIENTADOR: Prof. Dr. Carlos Frederico Bremer

São Carlos 
A Carol, Clara e Gabriel, razão do meu viver. Aos meus pais, minha origem e meu apoio. 


\section{Agradecimentos}

Ao Prof. Bremer, um incentivador e companheiro.

Aos professores e funcionários da Engenharia de Produção, pelo exemplo, amizade e apoio.

A Deloitte pelo apoio no início e no final deste trabalho, em especial ao Valmir, Nagata, Helton, Gabriel e Carlos.

A todos os companheiros da pós-graduação, em especial para:

Domingos, Rogério, Kamarão, Favaretto, Dinho, Giuliano, Uberaba, André Gustavo, Gustavo, Bob, Ricardo, Francis, Fernando e André. 


\section{SUMÁRIO}

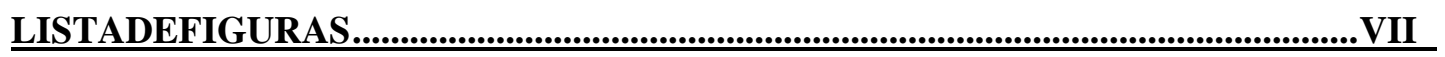

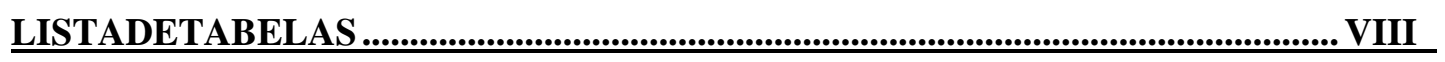

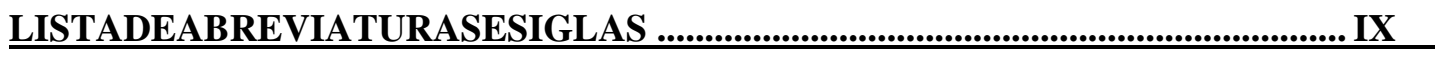

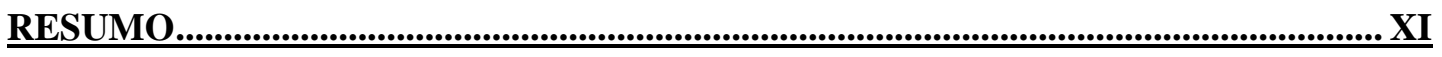

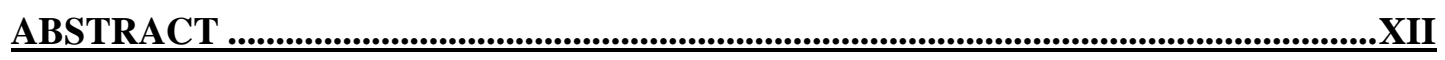

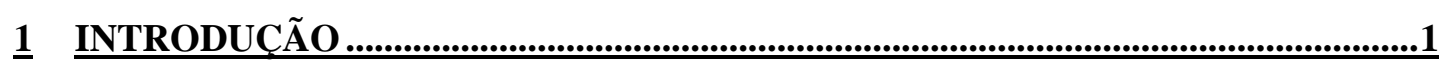

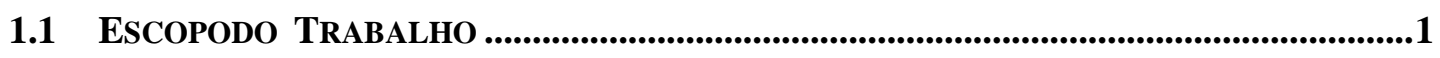

1.2 Metodologia Científica ......................................................................................

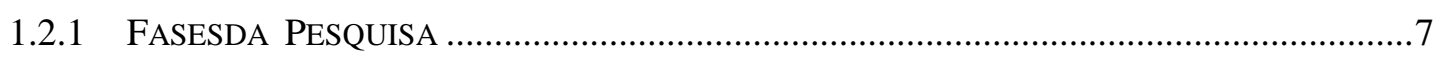

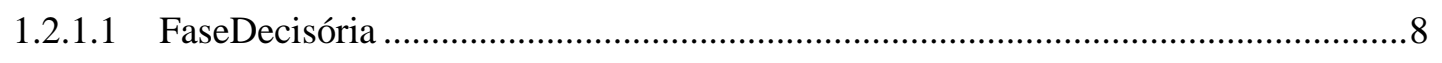

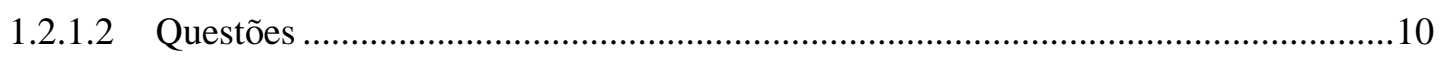

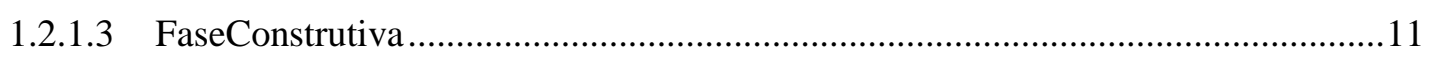

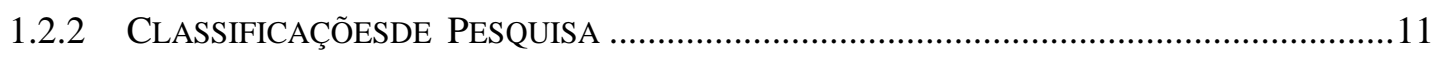

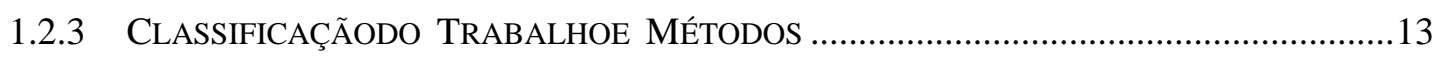

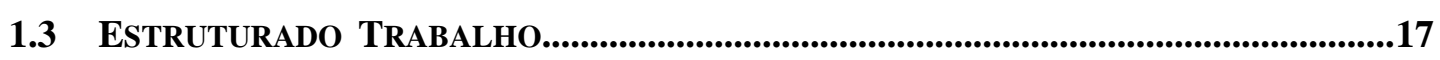

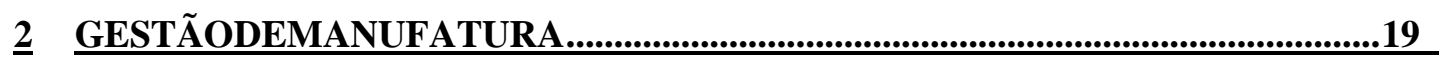

2.1 O DESENVOLVIMENTO DA MANUFATURA E O AMBIENTE ATUAL..............................21

$\underline{3}$ O PLANEJAMENTO E CONTROLE DE PRODUCÃO ....................................25 


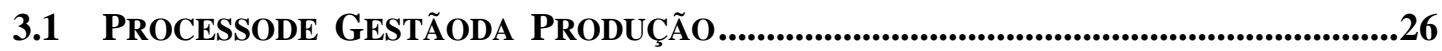

3.2 INTEGRAÇÃO DO PLANEJAMENTO E OUTRAS FUNÇÕES EMPRESARIAS .....................31

3.3 HiERARQUIA DE PlaneJAMENTO...............................................................................32

3.4 Sistemas e Filosofias de GeSTÃo da ProduÇão ...................................................35

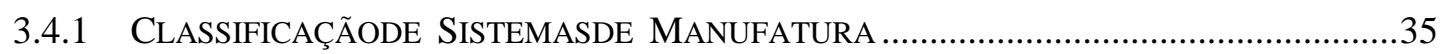

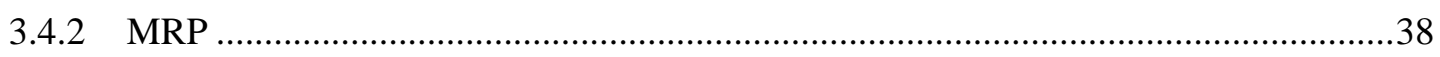

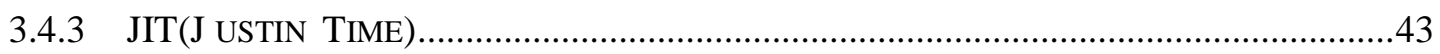

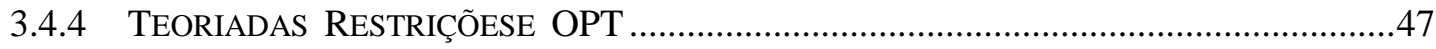

3.4.5 A GeSTÃo da CADEIA DE SUPRIMENTOS, OS Sistemas APS E OS NOVOS DESAFIOS

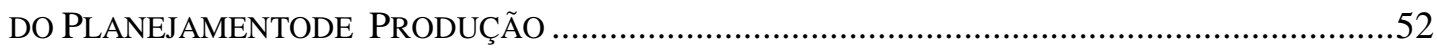

3.5 Considerações sobre o Planejamento de Produção e a coleta

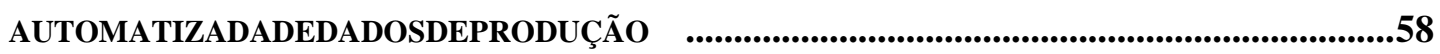

$4 \underline{\text { O PLANEJAMENTO E CONTROLE DE CHÃO-DE-FÁBRICA..........................64 }}$

4.1 Modelos FunCIONAIS PARA SISTEMAS de CHÃO-DE-FÁBRICA.............................66

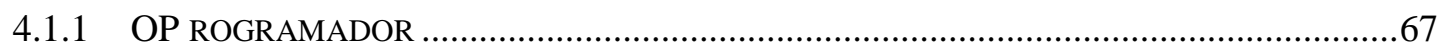

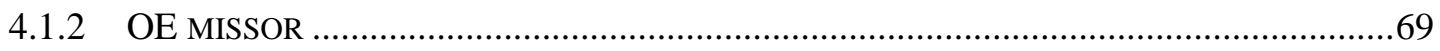

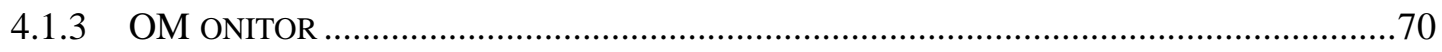

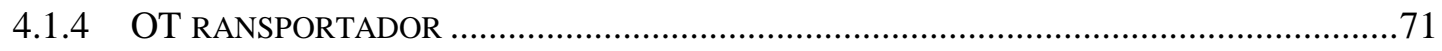

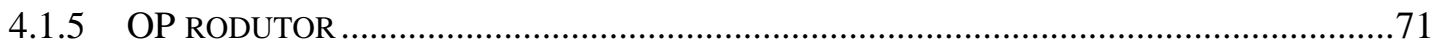

4.2 PROCESSO DE LIBERAÇÃo DE ORDENS .....................................................................71

4.2.1 TIPOLOGIA DE PRODUÇÃO NO PROCESSO DE LIBERAÇÃO DE ORDENS .........................75

4.3 ESTRATÉgia DE MOdelagem DE DAdOS PARA UM Sistema DE MANUFATURA

INTEGRADA

4.4 Aplicações de Sistemas de Controle de Produção em Ambientes de

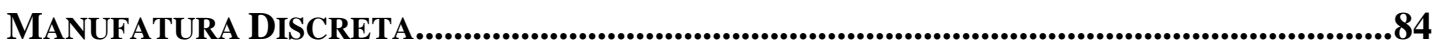


4.5 Coleta de Dados Automática e Seus Impactos na Produtividade..............92

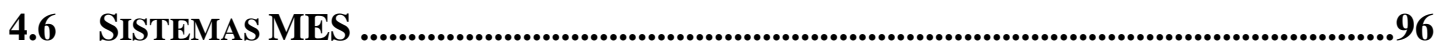

4.7 SISTEMAS SCADA _.............................................................................................................100

4.8 APLiCAÇÃo E DeSEnVOLVIMENTO de UM Sistema de Monitoramento do

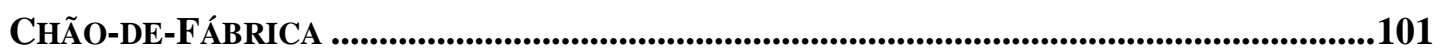

4.9 Considerações Sobre o Planejamento e Controle de Chão-de-Fábrica 103

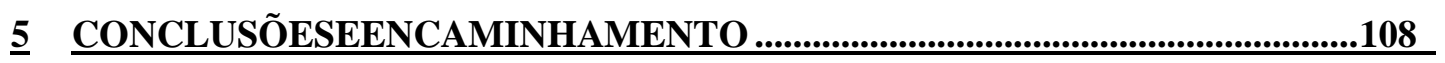

5.1 Fase de Diagnóstico do Sistema de MANUfatura..........................................109

5.2 Fase de Desenvolvimento de um Sistema de Planejamento e Controle 113

5.2.1 Modelo Funcional de Sistema de Planejamento e Controle De Chão-DE-

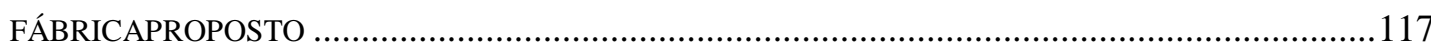

5.3 CONSIDERAÇÕES SOBRE TRABALHOS FUTUROS ......................................................123

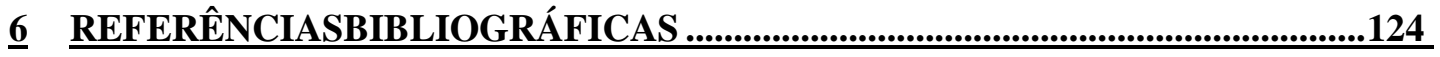




\section{LISTA DE FIGURAS}

FIGURA 1 - Proposta de Arquitetura de Sistema Supervisório .............................. 9

FIGURA 2 - Etapas de Desenvolvimento do trabalho...................................... 16

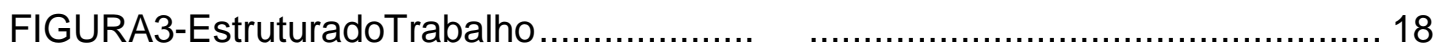

FIGURA 4 - Estrutura do Planejamento de Produção na Manufatura .................... 33

FIGURA 5 - Esquema de Processamento MRP .............................................. 40

FIGURA 6 - Arquitetura de Planejamento e Controle de Produção .........................66 66

FIGURA 7 - Modelo Funcional de Controle de Chão-de-Fábrica............................ 68

FIGURA 8 - Esquema Funcional de um Sistema de Liberação de Ordens............ 78

FIGURA 9 - Relacionamento dos Níveis Organizacionais e Tipos de Ordens ....... 79

FIGURA 10 - Estrutura do Fluxo de Informação do Sistema de Controle de

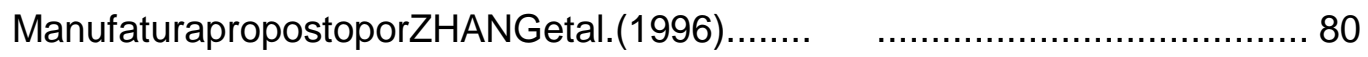

FIGURA 11 - Mecanismo de representação de atividade ..................................... 83

FIGURA 12 - Características para avaliação de uso de Sistemas de Programação Automatizados 91

FIGURA 13 - Funcionalidades dos Sistemas MES. 98

FIGURA 14 - Atividades no Desenvolvimento de um Sistema de Planejamento e Controle de Produção 114

FIGURA 15 - Relacionamento Domínio Físico da Manufatura e Sistemas 115

FIGURA 16 - Modelo funcional de Sistema SFC 


\section{LISTA DE TABELAS}

TABELA 1 - Decisões no Planejamento de Produção.

TABELA 2 - Tipologia de Sistemas de Produção e sua influência no processo de Liberação de Ordens. 74

TABELA 3 - Características das Plantas Industriais estudadas por McKAY \& BUZACOTT. 89

TABELA 4 - Sistemas de Coleta Automática de Dados estudados por LINDAU (1997) 92

TABELA 5 - Dimensões de Informação no Diagnóstico de um Sistema de Manufatura 


\section{LISTA DE ABREVIATURAS E SIGLAS}

$\begin{array}{ll}\text { AGV } & \text { Automated Guided Vehicles } \\ \text { APICS } & \text { American Production and Inventory Control Society } \\ \text { APQC } & \text { American Productivity and Quality Center } \\ \text { APS } & \text { Advanced Planning and Scheduling } \\ \text { ATO } & \text { Assemble-to-Order } \\ \text { CIM } & \text { Computer Integrated Manufacturing } \\ \text { CNC } & \text { Computerized Numeric Control } \\ \text { COSIMA } & \text { COntrol Systems for Integrated Manufacturing } \\ \text { CRP } & \text { Capacity Resource Planning } \\ \text { DNC } & \text { Distributed Numeric Control } \\ \text { DTO } & \text { Design-to-Order } \\ \text { ERP } & \text { Enterprise Resource Planning } \\ \text { ISA } & \text { European Strategic Program for Research and Development in Information } \\ \text { ESPRIT } & \text { Technology } \\ & \text { Engineering-to-Order } \\ \text { ETO } & \text { Instrument Society of America } \\ \text { FCS } & \end{array}$




\begin{tabular}{|c|c|}
\hline ISO & International Standards Organization \\
\hline JIT & Just-in-Time \\
\hline MES & Manufacturing Execution System \\
\hline MESA & Manufacturing Execution Systems Association \\
\hline MPS & Master Planning Scheduling \\
\hline MRP & Materials Requirement Planning \\
\hline MRP II & Manufacturing Resource Planning \\
\hline MTO & Make-to-Order \\
\hline MTS & Make-to-Stock \\
\hline NUMA & Núcleo de Manufatura Avançada \\
\hline PAC & Production Activity Control \\
\hline RCCP & Rough Cut Capacity Planning \\
\hline SCADA & Supervisory Control and Data Acquisition \\
\hline SCM & Supply Chain Management \\
\hline SFC & Shop Floor Control \\
\hline SOP & Sales and Operations Planning \\
\hline TOC & eory of Constraints \\
\hline
\end{tabular}




\section{RESUMO}

Junqueira, G. S. Análise das possibilidades de utilização de sistemas supervisórios no Planejamento e Controle de Produção. São Carlos, 2003. 143p. Dissertação (Mestrado) - Escola de Engenharia de São Carlos, Universidade de São Paulo.

O desempenho dos sistemas de Planejamento e Controle de Produção e dos sistemas de Planejamento e Controle de Chão-de-Fábrica é fortemente dependente da qualidade e confiabilidade dos dados de operação e da rapidez com que estes dados são obtidos para análise e acompanhamento da execução dos planos de produção. O processo de coleta e tratamento destes dados tem sido pouco detalhado nos modelos de referência encontrados na literatura. Este trabalho posicionou a utilização de sistemas supervisórios para a coleta de dados de produção em sistemas de planejamento e controle no ambiente da manufatura discreta, propondo um roteiro de atividades a serem consideradas no desenvolvimento de sistemas de planejamento.

Palavras-chave: Planejamento e Controle da Produção; Controle de Chão-deFábrica; Sistemas Supervisórios. 


\begin{abstract}
The Production Planning and Control Systems and Shop Floor Control Systems performance are extremely dependent of the quality and reliability of the operational data and readiness in data collection process, in order to provide information to analyse the execution of production plans. The data collection process has been rarely detailed in the reference models found in literature. This work locates the supervisory and control data acquisition systems role in the landscape of discrete manufacturing planning systems and proposes a routing of tasks to be considered in developing process of a manufacturing planning system.
\end{abstract}

Keywords: Production Planning and Control; Shop Floor Control; Supervisory Systems. 


\section{Introdução}

\subsection{Escopo do Trabalho}

A natureza dos problemas de gestão de manufatura na última década e meia têm mudado radicalmente. De um ambiente de demanda e tecnologia relativamente estáveis têm se hoje um ambiente onde os ciclos de desenvolvimento de produtos reduziram-se, a diversidade de produtos aumentou e o foco no atendimento das necessidades do cliente tornou-se primordial. Também temos um contexto onde a concorrência entre as empresas tornou-se virtualmente global, as organizações aumentaram de tamanho através de fusões e incorporações que estenderam a atuação das empresas por muitos países e como conseqüência o acesso à diversidade de produtos por parte do mercado ampliou-se grandemente em comparação ao passado recente.

Frente a estas mudanças, as empresas de manufatura viram-se obrigadas a mudar a maneira de como gerir suas operações, tanto para responder a estas mudanças quanto para tomar partido das oportunidades que surgiram deste novo contexto. Diminuição dos tempos do fluxo de produção, redução de estoques, melhoria da qualidade dos produtos, melhor atendimento dos prazos de entrega, coordenação da demanda global da cadeia de suprimentos, diminuição dos custos produtivos tornaram-se imperativos disseminados na gestão da manufatura nas empresas (LUMMUS et al., 1998).

Para responder a estes desafios, o papel do Planejamento e Controle de Produção (PCP) é central, pois são nas funções de planejamento e controle de produção que se desempenham as atividades básicas do processo de Gestão de Produção. Ao PCP cabe a tarefa de coordenar a alocação de recursos e de 
prioridades, desenvolvimento de planos de produção e controle da execução destes planos frente ao que fora.

Dentre as diversas tipologias de manufatura encontradas, destaca-se a complexidade inerente aos sistemas de manufatura discreta. Este tipo de manufatura se caracteriza como o mais complexo ambiente para o planejamento de produção (McKAY \& BUZACOTT, 2000). O ambiente característico deste tipo de manufatura é constituído de várias máquinas, com roteiros complexos e normalmente com várias alternativas de processamento possíveis, em equipamentos diferentes, muitas vezes podendo encontrar alternativas de processamento em paralelo e sendo estas desempenhadas com eficiências diferentes. Em geral, este tipo de processo produtivo também se caracteriza pela grande influência da habilidade e da capacidade de intervenção do operador no processo, o que soma complexidades na delimitação dos problemas de planejamento, coordenação e controle das operações. A influência da demanda e características de mercado a que este tipo de ambiente produtivo está sujeito pode variar muito, desde ambientes voltados à produção para estoques, produzindo produtos estáveis por anos seguidos até o de ambientes onde os produtos são inteiramente desenvolvidos e projetados para atender às especificações do cliente e onde os componentes serão produzidos uma única vez, para atender os requisitos de um produto específico produzido para um só cliente.

Contudo o que se encontra nas empresas, muito mais do que ambientes onde podemos definir claramente as características de mercado, produto e tecnologia não é na sua grande maioria uma clara distinção entre ambientes "puros" segundo as classificações possíveis de sistemas de manufatura, ou seja, é difícil encontrar empresas que operem exclusivamente como produção para estoque ou desenvolvimento de produto a pedido (ARTIBA \& ELMAGHRABY, 1996) ou 
qualquer das variações entre estes modelos, ou segundo os outros modelos de tipologia descritos pelos autores. Ao contrário, encontram-se sim, as empresas e plantas operando segundo uma combinação das várias tipologias apresentadas na literatura (ARTIBA \& ELMAGHRABY, 1996).

As formas e técnicas de planejamento têm tentado se adequar a esta nova realidade, contudo as filosofias e técnicas de gestão de produção, tiveram seu entendimento por parte de práticos e teóricos bastante evoluído nos últimos anos, conjuntamente com uma evolução notável da tecnologia da informação nos últimos dez anos, ainda apresentam marcantes lacunas, sendo uma das principais, sobre o qual trata este trabalho, a da falta de informações confiáveis sobre o qual se desenvolva o planejamento de produção.

Esta informação é tão mais vital aos sistemas de planejamento e controle de produção quanto mais complexas forem as operações de manufatura e estrutura de produtos, situação esta cujo ápice de complexidade encontramos na manufatura discreta, em especial das oficinas de produção da indústria mecânica.

As três grandes filosofias e técnicas de manufatura, Just-in-Time, MRP e Teoria das Restrições, cuja relevância encontra respaldo na literatura existente em Planejamento e Controle de Produção, podem ser ditas dominantes na maior parte das empresas de manufatura (BAUER et al., 1991; BROWNE et a., 1988; VOLLMANN et al., 1997). Estas maneiras de se executar o planejamento muito dizem em seus modelos e trabalhos sobre a lógica e hierarquia dos planos, sobre a necessidade do fluxo de informações das operações para os níveis mais agregados de planejamento e controle e realimentação para os níveis mais inferiores, contudo pouco definem e apresentam sobre as formas de coleta e tratamento destas informações. 
Em paralelo com as grandes filosofias e técnicas de gestão de produção, acima reportadas, existem um grande número de modelos de sistemas de informação (BANERJEE, 1996), metodologias de modelagem de dados, de desenvolvimento de sistemas, de técnicas analíticas e práticas associadas ao planejamento e controle de chão-de-fábrica. Estes sistemas e técnicas, mais ainda apontam a coleta de dados de chão-de-fábrica, convertidos em informações utilizáveis, como chave para a boa gestão das operações e eficiente execução das atividades de manufatura segundo os requisitos empresariais de cada empresa.

O desenvolvimento de aplicações para coleta de dados de chão-de-fábrica tem proporcionado a oportunidade para que se supere a crônica deficiência de informações para um funcionamento otimizado dos sistemas de planejamento e controle de produção. Isto pode ser dito, tanto quanto aos sistemas de planejamento e controle de produção de nível mais agregado, onde se encontram os sistemas de planejamento MRP, quanto aos sistemas de planejamento e controle de chão-de-fábrica, que tratam dos problemas de sequenciamento de operações com capacidade finita, onde se encontram os sistemas de programação com capacidade finita, conhecidos como sistemas FCS (Finite Capacity Scheduling) ou APS (Advanced Planning and Scheduling)(ROWEN, 1999).

A partir dos trabalhos iniciais de CAETANO (2000) e MEIRELES (2000) que exploraram a oportunidade técnica de desenvolvimento de sistemas de coleta automática de dados de manufatura do chão-de-fábrica, na manufatura discreta, diretamente de equipamentos CNC (Computerized Numeric Control) e através de sensores, este trabalho visa apresentar um estudo do planejamento e controle de produção, sendo considerado dentro do processo de planejamento e controle de produção, especialmente o planejamento e controle de chão-de-fábrica, vislumbrando situar a coleta de dados de produção e as possibilidades de utilização 
de sistemas supervisórios SCADA (Supervisory Control and Data Acquisition Sistemas de Controle Supervisório e de Aquisição de Dados), anteriormente utilizados no controle e supervisão da indústria de processos químicos, sobre o Planejamento e Controle de Produção.

O ineditismo dos trabalhos de CAETANO (2000) e MEIRELES (2000), não reside simplesmente na coleta de dados automatizada, mas sim, na possibilidade de suplantar os métodos usuais destas coletas e garantir uma conexão em tempo real com equipamentos de manufatura discreta, onde num contexto de utilização conjunta com sistemas de coleta automatizada de dados usuais (coleta através de códigos de barras, radiofreqüência, tags magnéticos e outros), pode auxiliar em muito, os sistemas de planejamento e em especial, viabilizar os sistemas de planejamento e controle de chão-de-fábrica focados no controle e sequenciamento de operações de manufatura. Assim, se torna possível a visualização do status das operações em tempo real e viabiliza a utilização de regras de sequenciamento, modelos analíticos-quantitativos e simulações de curto prazo no contexto de reprogramações de curto prazo, através do monitoramento de eventos inesperados e evitando a propagação destes "distúrbio" através da cadeia de produção.

Desta forma, este trabalho pretende contribuir para o entendimento da utilização de sistemas de supervisórios de coleta de dados de chão-de-fábrica, de forma a suprir as lacunas dos atuais sistemas de gestão de produção quanto ao acompanhamento das operações, através do estudo do papel das informações de operação nos sistemas de planejamento de produção, dos modelos de sistemas propostos pela literatura, das possibilidades de utilização de sistemas supervisórios e da proposição de um roteiro de atividades que o projeto, desenvolvimento e implementação de um sistema de planejamento e controle de chão-de-fábrica deve 
considerar para uma utilização eficiente apontando as fases que podem e devem se utilizar sistemas do tipo SCADA. 


\subsection{Metodologia Científica}

Segundo SILVA \& MENESES (2000) a resposta para a pergunta sobre o que vem a ser pesquisa pode ser dado de forma bastante simplificada como “...procurar respostas para indagações propostas”.

MINAYO apud SILVA \& MENESES (2000) ${ }^{1}$ apresenta um ponto de vista mais formal e bastante completo onde a pesquisa é definida como "atividade básica das ciências na sua indagação e descoberta da realidade. É uma atitude e uma prática teórica de constante busca que define um processo intrinsecamente inacabado e permanente. É uma atividade de aproximação sucessiva da realidade que nunca se esgota, fazendo uma combinação particular entre teoria e dados".

\subsubsection{Fases da Pesquisa}

Quanto às fases da pesquisa, foi seguida uma construção para este trabalho segundo o ponto de vista de SILVA \& MENESES (2000), em:

Fase Decisória: referente à escolha do tema, a definição e a delimitação do problema de pesquisa;

Fase Construtiva: referente à construção de um plano de pesquisa e à execução da pesquisa propriamente dita;

Fase Redacional: referente à análise dos dados e informações obtidas na fase construtiva. É a organização das idéias de forma sistematizada visando à

${ }^{1}$ MINAYO, M.C.S. (1993). O desafio do connhecimento. Hucitec, apud SILVA, E.L.; MENEZES, E.M. (2000). Metodologia da pesquisa e elaboração de dissertação. Florianópolis. Laboratório de Ensino a Distância - Universidade Federal de Santa Catarina. $118 p$. 
elaboração do relatório final. A apresentação do relatório de pesquisa às formalidades requeridas pela academia.

\subsubsection{Fase Decisória}

Quanto a Fase Decisória de escolha do tema e de definição e delimitação do tema de pesquisa, os trabalhos iniciados por CAETANO (2000) e MEIRELES (2000), ainda durante o ano de 1999, no âmbito do NUMA (Núcleo de Manufatura Avançada da USP/S.CARLOS), vieram a dar ensejo ao estudo das possibilidades de implantação de redes de coleta de dados, para fins de supervisão e monitoramento de dados de chão-de-fábrica ${ }_{2}$ na manufatura discreta. A aceitação do estudo das possibilidades de integração dos dados obtidos com sistemas ERP (Enterprise Resources Planning) e de Planejamento e Controle de Chão-de-Fábrica (SFC - Shop Floor Control) como relevantes ao meio acadêmico e empresarial foi corroborada pela premiação do Projeto IPROS (Integrated Production and Supply Chain Management), dentro do programa de premiação para projetos acadêmicos da SAP Américas (SAP University Alliance Grant Awards Program). 


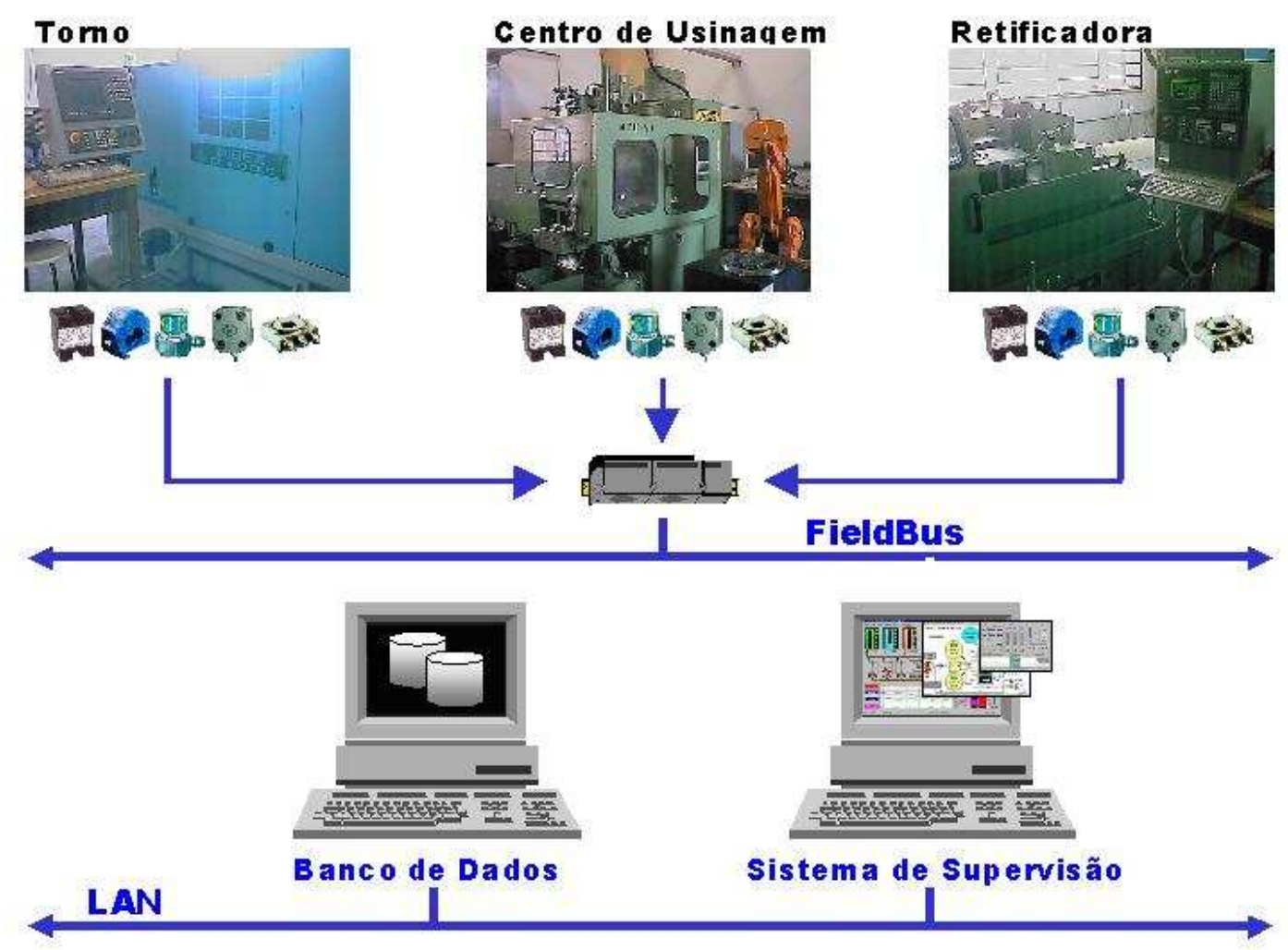

FIGURA 1 - Proposta de Arquitetura de Sistema Supervisório

(CAETANO et al., 1999)

Os trabalhos originais de CAETANO (2000) e MEIRELLES (2000)(Figura 1), visavam a utilização de redes de campo, para a coleta de dados provenientes de sistemas CNC e de sensores acústicos e de potência, para a criação de sistemas supervisórios do tipo SCADA (Supervisory Control and Data Acquisition - Sistemas de Controle Supervisório e de Aquisição de Dados), sendo sua motivação originalmente voltada à aplicação das novas tecnologias, tanto de hardware quanto de software para chão-de-fábrica, quanto ainda à aplicação dos desenvolvimentos na área de sensoriamento para aplicação na otimização de processos de usinagem, desenvolvidos na USP/S.Carlos (NUMA - Laboratório de Otimização de Processos de Fabricação - OPF), possibilitando a coleta de dados e monitoramento de 
processos de produção, para otimização de ciclos de processos e melhor entendimento dos fenômenos físicos envolvidos na usinagem de metais. Contudo, estes estudos visavam também abrir caminho para a coleta de dados de produção, voltados à melhoria da gestão da manufatura em ambientes de manufatura discreta, através da coleta de dados e geração de informações tais como: quantidade de peças produzidas; ritmo de produção; tempos de processo, setup, paradas; motivos de parada (manutenção, quebra de ferramenta, falta de material, setup) (CAETANO; 2000).

A questão de pesquisa que surge daí, período do início da concepção deste trabalho, é a de que como aproveitar esta possibilidade tecnológica viável (FAVARETTO; 2000), na integração com os módulos de manufatura de sistemas ERP, e em especial, com os sistemas de planejamento de produção, entendendo aqui, sistemas de planejamento de produção não simplesmente como software, com suas regras implícitas e fluxo de informações, mas principalmente como um conjunto de atividades ordenadas, onde decisões são tomadas, há entrada de recursos e saídas na forma de produtos ou alterações de estado e onde o componente humano desempenha tarefa central no desempenho deste sistema (BONNEY, 2000).

\subsubsection{Questões}

De um estudo que aborde as questões pertinentes às possibilidades de utilização de um sistema supervisório no planejamento e controle de produção, derivam as seguintes questões: 


\section{Questão Principal:}

Como aproveitar esta possibilidade tecnológica, de coleta de dados de Chão-deFábrica, na integração com os sistemas de gestão de produção e quais são as oportunidades e implicações daí advindas?

\subsubsection{Fase Construtiva}

Partindo então de uma restrição do objeto de estudo e da construção de uma proposta de objetivos para este trabalho, toma forma o trabalho, caracterizando assim sua Fase Construtiva, necessitando então, de um embasamento metodológico para a formulação de uma proposta de trabalho.

Para tal, necessitamos classificar o trabalho dentro das várias formas de pesquisa.

\subsubsection{Classificações de Pesquisa}

Segundo a proposta de classificação da Pesquisa compilada por SILVA \& MENEZES (2000), podemos classificar a Pesquisa, segundo a natureza do problema abordado:

Pesquisa Básica: cujo objetivo é gerar conhecimentos novos úteis para o avanço da ciência sem aplicação prática prevista.

Pesquisa Aplicada: cujo objetivo é gerar conhecimentos para aplicação prática dirigidos à solução de problemas específicos. Envolve verdades e interesses locais.

Segundo a forma de abordagem do Problema:

Pesquisa Quantitativa: considera que tudo pode ser quantificável, o que significa traduzir em números opiniões e informações para classificá-los e analisá-los. MARTINS (2000) enfatiza as preocupações principais da abordagem quantitativa na mensurabilidade, casualidade, generalização e na replicação do experimento; 
Pesquisa Qualitativa: considera que há uma relação dinâmica entre o mundo real e o sujeito, isto é, um vínculo indissociável entre o mundo objetivo e a subjetividade do sujeito que não pode ser traduzido em números. A interpretação dos fenômenos e a atribuição de significados são básicos no processo de pesquisa qualitativa, não requerendo uso de métodos e técnicas estatísticas. O ambiente natural é a fonte direta para a coleta de dados e o pesquisador é o instrumento chave. É descritiva. Os pesquisadores tendem a analisar seus dados indutivamente. O processo e seu significado são os focos principais de abordagem.

Segundo o ponto de vista de seus objetivos:

Pesquisa Exploratória: visa proporcionar maior familiaridade com o problema com vistas a torná-lo explícito ou a construir hipóteses. Envolvem levantamento bibliográfico; entrevistas com pessoas que tiveram experiência práticas com o problema pesquisado; análise de exemplos que estimulem a compreensão;

Pesquisa Descritiva: visa descrever as características de determinada população ou fenômeno ou o estabelecimento de relações entre variáveis. Envolvem o uso de técnicas padronizadas de coleta de dados: questionário e observação sistemática. Assume em geral a forma de levantamento;

Pesquisa Explicativa: visa identificar os fatores que determinam ou contribuem para a ocorrência dos fenômenos, aprofunda o conhecimento da realidade porque explica a razão, o porquê das coisas. Quando realizada nas ciências naturais requer o uso do método experimental e nas ciências sociais requer o uso do método observacional. Assume, em geral, as formas de Pesquisa Experimental e Pesquisa Ex-Post-Facto.

Segundo os procedimentos técnicos:

Pesquisa Bibliográfica: quando elaborada a partir de material já publicado;

Pesquisa Documental: quando elaborada a partir de materiais que não receberam tratamento analítico;

Pesquisa Experimental: quando se determina um objeto de estudo, selecionando-se as variáveis que seriam capazes de influenciá-lo, definindo-se 
as formas de controle e de observação dos efeitos que a variável produz no objeto;

Estudo de Caso: quando envolve o estudo profundo e exaustivo de um ou poucos objetos de maneira que se permita seu amplo e detalhado conhecimento;

Pesquisa Ex-Post-Facto: quando o experimento se realiza depois dos fatos;

Pesquisa Ação: quando concebida e realizada em estreita associação com uma ação ou com a realização de um problema coletivo;

Pesquisa Participante: quando se desenvolve a partir da interação entre pesquisadores e membros das situações investigadas.

\subsubsection{Classificação do Trabalho e Métodos}

Da análise destas classificações do tipo de pesquisa, podemos concluir deste trabalho, que: consiste em Pesquisa Aplicada, pois visa gerar conhecimentos para aplicação prática, como podemos classificar a maior parte da pesquisa gerada no âmbito da Engenharias e das Ciências Administrativas; podemos ainda classificar a pesquisa como principalmente qualitativa, pois temos um "..foco nos processos do objeto de estudo..", (MARTINS, 2000).

Quanto aos objetivos, este trabalho pode ser classificado como Descritivo, na medida em que tenta descrever as características de um fenômeno, ou seja, o impacto da utilização da coleta de dados de chão-de-fábrica, na Gestão da Produção em geral, e no Planejamento e Controle de Produção em particular. Contudo o trabalho também é Exploratório, na medida em que visa proporcionar familiaridade com o problema, com vistas à torná-lo explícito, podendo construir hipóteses para discussão e construção de relações que ajudem a explicar o objeto em estudo.

Quanto aos procedimentos técnicos, esta pesquisa se propõe à utilização dos procedimentos de: Pesquisa Bibliográfica (majoritariamente); Levantamento, 
pois já existem aplicações para o objeto de estudo, tanto de maneira independente da academia, visto o número de soluções comerciais, quanto da própria experiência USP/S.CARLOS - NUMA, de aplicações em projetos de extensão, com empresas parceiras e sobre os quais, já se encontram exemplos de dissertações e teses produzidas, que tocam com enfoques diferentes à aplicabilidade de tais sistemas (CAETANO, 2000; FAVARETTO, 2001; MEIRELES, 2000; MELLO, 2002); dado às pesquisas desenvolvidas na USP/São Carlos.

Quanto aos métodos científicos utilizados na literatura sobre o assunto, é convergente a definição dos seguintes métodos (LAKATOS \& MARCONI, 1983) :

Método Dedutivo: o raciocínio dedutivo tem o objetivo de explicar o conteúdo das premissas, visa explicar o específico a partir de leis gerais, sendo central o encadeamento lógico de premissas para se chegar a uma conclusão;

Método Indutivo: o Método proposto pelos empiristas, considera que o conhecimento é fundamentado na experiência, não levando em conta princípios estabelecidos. A partir de constatações particulares, busca a generalização;

Método Dialético: método no qual a busca à solução é feita no mundo dos fenômenos por meio da ação recíproca, da contradição inerente ao fenômeno e da mudança dialética que ocorre na natureza e na sociedade;

Método Hipotético Dedutivo: “...consiste na construção de conjecturas, que devem ser submetidas a testes, os mais diversos possíveis, à crítica intersubjetiva, ao controle mútuo pela discussão crítica, à publicidade crítica e ao confronto com os fatos, para ver quais as hipóteses que sobrevivem como mais aptas pela vida, resistindo portanto, às tentativas de refutação e falseamento." (LAKATOS \& MARCONI, 1983). 
Embora exista um caráter descritivo da pesquisa, o que poderia demandar a utilização dos métodos dedutivos e indutivos, a opção da utilização do Método Hipotético Dedutivo, recai como a preferida, dado ao conteúdo exploratório do trabalho, ser caracterizado por um espírito de trabalho que busca levantar questionamentos, explorando possibilidades sobre um assunto ainda pouco explorado e ainda parcamente difundido na indústria, que contudo se avizinha como uma tendência para a manufatura moderna, através da maior utilização das soluções APS (Advanced Planning and Scheduling - Planejamento e Programação Avançados) (JUNQUEIRA et al., 2000) e da emergência das ferramentas que suportam o desenvolvimento da Gestão da Cadeia de Suprimentos (Supply Chain Management) que vêem a ressaltar a necessidade tanto de uma maior confiabilidade de dados de chão-de-fábrica, quanto de uma maior velocidade de atualização dos dados de operação de manufatura (ALVORD, 1999), dado que a disponibilidade de dados confiáveis e atualizados constitui em elemento chave no compartilhamento de informações da cadeia de suprimentos (LUMMUS et al., 1998).

A Figura 2, sumariza as etapas de construção deste trabalho: 


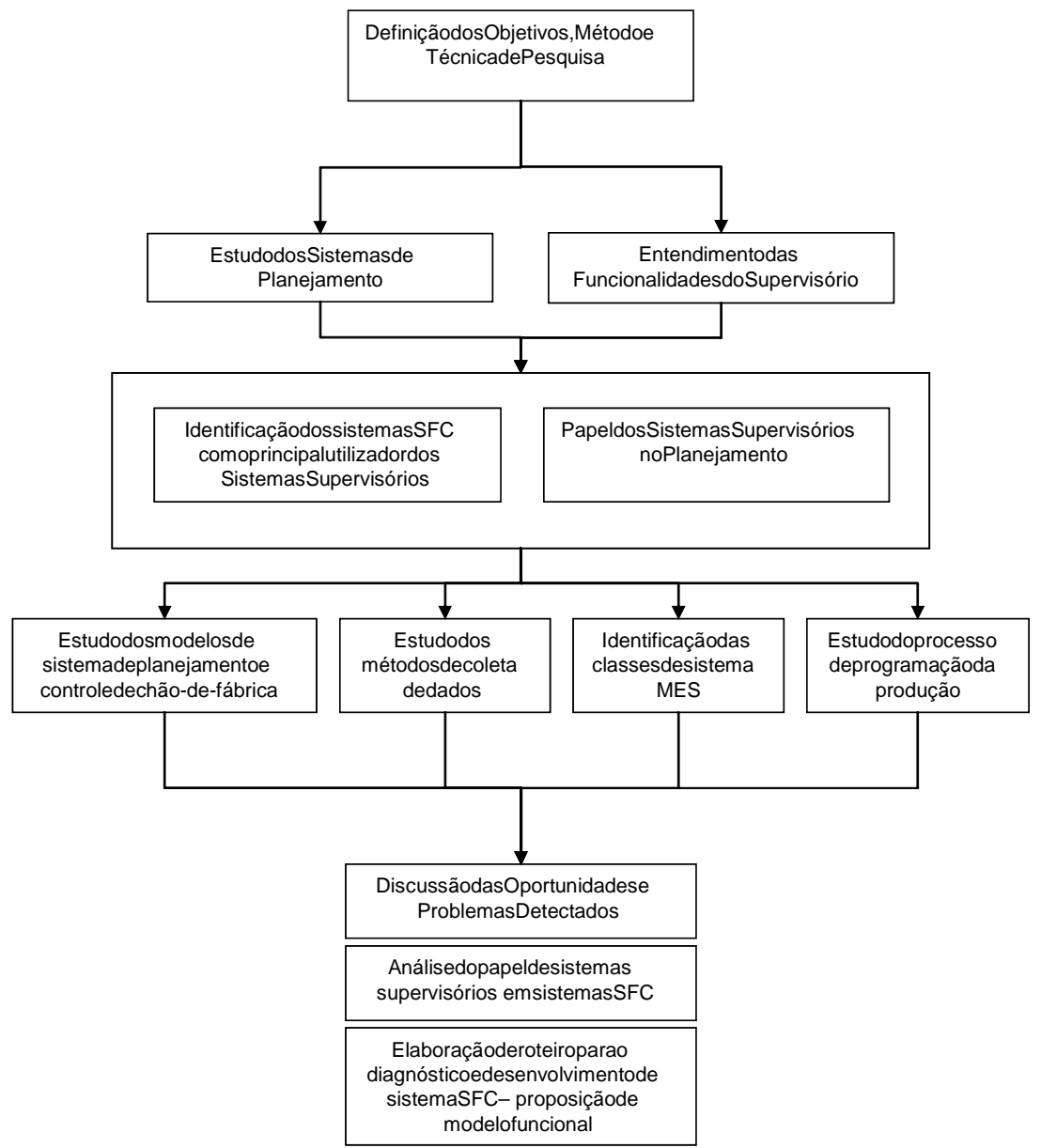

FIGURA 2 - Etapas de Desenvolvimento do trabalho 


\subsection{Estrutura do Trabalho}

Este trabalho está dividido da seguinte forma:

$\checkmark$ Introdução: onde se situa o problema de pesquisa, as formas e possibilidades de utilização de sistemas supervisórios no ambiente de chãode-fábrica, descreve-se a metodologia de pesquisa, através da apresentação breve das motivações do projeto e também da perguntas de pesquisa;

$\checkmark$ Gestão de Manufatura: onde é apresentado um breve histórico da evolução da Gestão de Produção e localiza-se o ambiente de manufatura atual;

$\checkmark$ O Planejamento e Controle de Produção: onde se define o processo de gestão de produção, apresentam-se as principais filosofias e técnicas de Gestão de Produção: JIT, MRP e Teoria das Restrições, apresentando-se aí uma relação entre a utilização da coleta automatizada de dados e o planejamento de produção.

$\checkmark$ O Planejamento e Controle de Chão-de-Fábrica: onde se define 0 Planejamento e Controle de Chão-de-Fábrica, analisando-se os modelos de sistemas, os métodos de coleta-de-dados, sistemas supervisórios e sua integração com estes sistemas. Posiciona-se então, os sistemas SCADA como suporte essencial aos sistemas de Planejamento e Controle de Chãode-fábrica;

$\checkmark$ Conclusões, onde se apresenta um breve roteiro sobre as atividades fundamentais no diagnóstico e desenvolvimento de um sistema de planejamento e controle de chão-de-fábrica para a manufatura discreta e se apresenta um modelo funcional de sistema de chão-de-fábrica que considere a coleta de dados de chão-de-fábrica com sistema supervisório, desenvolvido 
neste trabalho, com base nos diversos modelos consultados no desenvolvimento deste trabalho e considerações apresentadas.

A Figura 3 apresenta a descrição do conteúdo dos capítulos:

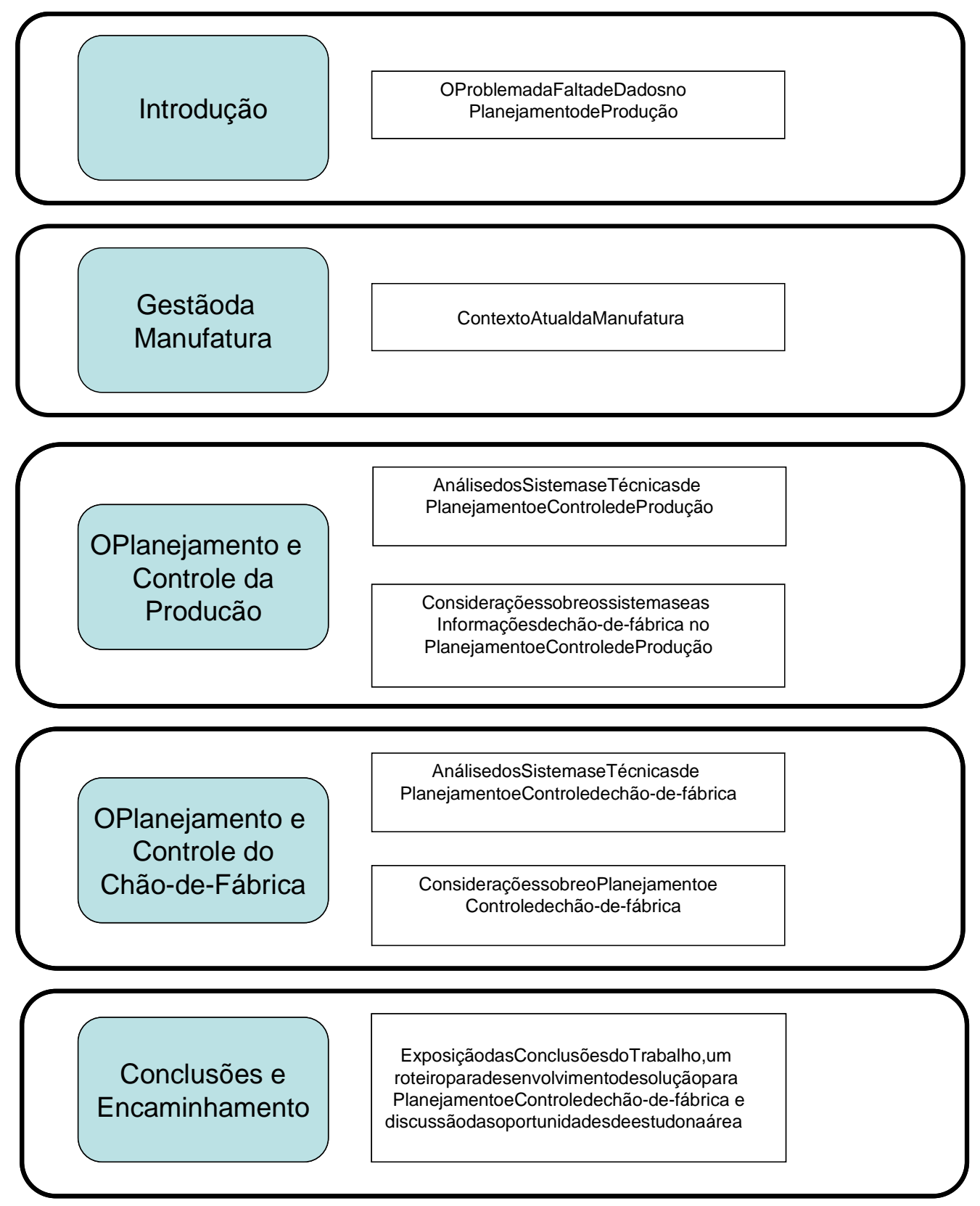

FIGURA 3 - Estrutura do Trabalho 


\section{Gestão de Manufatura}

Algumas tendências de mercado que começaram a serem delineadas nos anos 80 , cristalizaram-se e tornaram-se determinantes na economia nos anos 90 e começo desta década. Foco no cliente e conseqüente segmentação de mercado (KAPLAN \& NORTON. 1997); contínua internacionalização e crescimento das corporações aliado à consolidação da prática de fornecimento global (Global Sourcing) (VOLLMANN et al., 1997); diminuição dos ciclos de vida dos produtos (BROWNE et al., 1988); enorme desenvolvimento da tecnologia da informação e grande velocidade de difusão tecnológica (KAPLAN \& NORTON ,1997).

Temos então um novo contexto econômico para a sociedade cujo reflexo é direto na manufatura, onde os modelos de produção baseados nos ganhos de escala e padronização, que se desenvolveram desde o início do século $X X$, ambiente de desenvolvimento da Administração Científica de Taylor e Fayol e que atingiram seu ápice nos vinte anos seguintes a $2^{\mathrm{a}}$ grande guerra mundial e continuaram dominantes mesmo nos anos seguintes, da crise do petróleo, perdurando até o fim da década de 80 , são questionados e suplantados por uma nova situação (KAPLAN \& NORTON, 1997). Situação esta, em que o setor industrial é levado a um novo patamar de complexidade, dado a gama bem mais ampla de produtos que o mercado passa a demandar. Assim, a gestão da manufatura é desafiada ao desenvolvimento de um novo modelo, que leva ao surgimento de novas filosofias de gestão de manufatura e a um enorme aprimoramento do conhecimento já existente.

A função produção, como definido escola estruturalista de Administração, passa a ser reconhecida como tendo um papel fundamental no sucesso das 
corporações, passando a ser melhor designada como função "Manufatura" (CHIAVENATO, 1993; PIRES, 1998).

Muito da elevação da função produção ou manufatura, a um papel estratégico na organização, se deveu ao enorme crescimento econômico japonês ocorrido nas décadas de 60, 70 e 80, (PIRES, 1995), tendo sido este desenvolvimento industrial a base sobre a qual se edificou o desenvolvimento econômico japonês, tendo sido assim que segundo um inequívoco espírito exportador, baseado na melhoria contínua da manufatura e adaptação a um estilo de manufatura de menores lotes focados na customização através da máxima diversificação, veio o Japão e os produtos japoneses a lograr enorme penetração nos países do ocidente, em especial nos Estados Unidos (WOMACK \& JONES, 1998). Digamos que, mais surpreendente ainda foi a evolução da percepção que o consumidor ocidental tinha dos produtos Japoneses na década de 60 , de produtos baratos, desprovidos de conteúdo tecnológico e de baixa qualidade para a visão de produtos sofisticados, de alta sofisticação tecnológica, alcançando reputada qualidade e em diversidade sem precedentes (FLEURY \& FLEURY, 1995).

Em que pese a situação de estagnação econômica do Japão nos últimos dez anos, o fato é que a ameaça que seu crescimento industrial e de seus produtos representou ao estilo ocidental de manufatura, leiamos Europa e América, e por conseqüência também ao estilo de manufatura predominante no Brasil (FLEURY \& FLEURY, 1995), havendo assim, um questionamento ao dominante "estilo de fazer negócios" ocidental, cuja influência dominante é o estilo de gestão Americano, que no seu corpo ideológico básico sempre reputou maior relevância ao sucesso empresarial nas atividades de gestão financeira e de marketing, invariavelmente relegando a manufatura a uma posição de baixo prestígio. É portanto, desta 
maneira que se imputa o papel de mola impulsionadora da elevação da manufatura a papel central de sucesso das corporações industriais ao sucesso Japonês.

\subsection{O desenvolvimento da manufatura e o ambiente atual}

Os métodos japoneses de gestão da manufatura vieram a ser denominados genericamente no ocidente pelo nome da prática básica de fornecimento e de programação das células do chão-de-fábrica japonês, "Just-in-Time", nome que veio a batizar a filosofia japonesa de produção, hoje já bem conhecida no ocidente e devidamente aperfeiçoada e adaptada - frise-se a popularização recente do conceito de "Lean Manufacturing" (WOMACK \& JONES, 1998), sendo estudados e reputados como a base e suporte principal da estratégia de máxima diversificação dos produtos e segmentação de mercados.

No ocidente ORLICK desenvolveu o algoritmo MRP, Materials Requirement Planning, rapidamente surgindo o MRP II, Manufacturing Resources Planning, que utilizando o desenvolvimento da tecnologia da informação, gerou uma forma estruturada de planejamento de Produção, que logo tomou ares de filosofia de gestão da produção e assim, inaugurou uma forma de utilização generalizada da informática na gestão da manufatura (BROWNE et al., 1988; LAURINDO \& MESQUITA, 2000). Mesmo que este desenvolvimento tenha se dado basicamente de forma focada no plano gerencial da manufatura e independente do desenvolvimento de sistemas eletroeletrônicos nos equipamentos de manufatura e de outras aplicações de suporte, sua disseminação foi rápida, através da utilização de softwares CAD/CAM e de máquinas $\mathrm{CN}$ e CNC que tomaram impulso 
concomitantemente ao desenvolvimento da eletroeletrônica aplicada às máquinas operatrizes (KENWORTHY apud LAURINDO \& MESQUITA, 2000)².

Já em meados dos anos 80, surge o sistema OPT, "Optimized Production Technology" (SOUZA, 1997), software cujos conceitos básicos popularizados pelo livro A Meta, tomam forma como pensamento sistêmico, ganhando corpo no que se batizou como "Teoria das Restrições", teoria esta que promove a junção da aplicação de conceitos matemáticos e heurísticos a uma série de preceitos da filosofia Just-in-Time.

O fim dos anos 90 encontra então os autores acadêmicos e de negócios, classificando "Just-in-Time", MRP e Teoria das Restrições como as formas básicas de gestão de produção, entendendo-se aqui formas em um sentido lato de filosofias, técnicas e práticas. Contudo, também se aceita comumente, que as filosofias não são incompatíveis entre si, podendo conviver em situações específicas se suficientemente coordenadas, o que na verdade acaba por ser a prática adotada em um grande número de empresas (ARTIBA \& ELMAGHRABY, 1996; CORREA et al., 1997; SLACK et al., 1999).

No que tange a conceituação da gestão da manufatura, as classificações e formas de melhoria de desempenho da manufatura não se restringem as três formas, que aqui chamamos de clássicas, conforme anteriormente citadas, porém devemos reconhecer a constante evolução e surgimento de idéias, técnicas e

${ }^{2}$ KENWORTHY, J. (1997). Planning and Control of Manufacturing Operations. John Wiley, apud LAURINDO, F. \& MESQUITA, M.A. (2000). Materials Requirement Planning: 25 anos de história - Uma revisão do passado e prospecção do futuro. Gestão \& Produção. v73, p.320-337. 
práticas durante o transcorrer das duas últimas décadas do século passado até agora, havendo concomitante ao desenvolvimento e "enraizamento" destas três filosofias/técnicas de gestão de produção que podem hoje ser denominadas como clássicas (PORTER et al., 1999).

Dentre as técnicas e conceitos que tocam a gestão da manufatura se destaca o aparecimento do CIM, Computer Integrated Manufacturing, da norma ISO-9000, da reengenharia e de sua sucedânea gestão por Processos de Negócio (Business Process), também "fundida" a reengenharia de negócios para formar o que se chamou Business Process Reengineering (Reengenharia dos Processos de Negócio). Viu-se também a evolução paralela dos softwares de gestão empresarial, ERP (Enterprise Resources Planning), que podem ser conceituados como a integração dos diversos sistemas de informação que antes eram isolados no suporte a atuação de empresas, em sistemas integrados, que suportam os diversos processos de negócio da empresa, utilizando-se bases de dados comuns (NÚCLEO DE MANUFATURA AVANÇADA, 2002).

Por fim, nos últimos anos, assistimos a emergência da filosofia da Gestão da Cadeia de Suprimentos, que suportada pelo desenvolvimento da Tecnologia da Informação e impulsionada pela fusão da tecnologia de informática à tecnologia da comunicação desempenha papel central na Gestão da Manufatura (GUPTA, 2000).

Destacamos também as práticas que se colocam na fronteira do desenvolvimento acadêmico, podendo a vir configurar tendências para os próximos anos, tanto pelo interesse acadêmico quanto pelas possibilidades práticas que oferecem, ainda mais no novo patamar de colaboração, comunicação e inteligência, proporcionado pela Tecnologia da Informação, tomando destaque à criação de Empresas/Organização Virtuais (GOULART, 2000) ou ainda pela aplicação matemática avançada à Gestão da Manufatura representada pela Pesquisa 
Operacional, cuja aplicação na manufatura, recai na zona cinza de definição das interfaces entre o continuum mal definido pelo fluxo de material, através dos limites de objeto de estudo Manufatura, Logística e Distribuição, cuja atribuição é muitas vezes encontrado no âmbito de Vendas/Marketing, mas o qual certamente não pode fugir a definição de ter sua importância contextualizada no Processo de Negócio Produzir e Distribuir (APQC, 1998). Ressalte-se que o desenvolvimento da Tecnologia da Informação e do conceito de Gestão da Cadeia de Suprimentos proporcionou o ressurgimento fortalecido das técnicas e heurísticas da Pesquisa Operacional, consubstanciados nos sistemas APS (Advanced Planning and Scheduling - Planejamento e Programação Avançada), que podem ser definidos como uma série de ferramentas que se utilizam a Pesquisa Operacional, para atingir soluções balanceadas, integrando sistemas ERP e a cadeia de suprimentos através de sistemas de informação colaborativos (ROWEN, 1999). 


\section{O Planejamento e Controle de Produção}

Podemos considerar o Planejamento e Controle de Produção, como a parte central na gestão do que hoje podemos chamar de Processo de Negócio Produzir e Distribuir, entendido processo de negócio como um fenômeno que ocorre dentro das empresas contendo um conjunto de atividades, associadas às informações que manipula, utilizando os recursos e a organização da empresa. Formando assim uma unidade coesa e que deve ser focalizado em um tipo de negócio, que normalmente está direcionado a um determinado mercado/cliente, com fornecedor/cliente bem definidos (ROZENFELD, 1996).

Utilizamos aqui, neste ponto do trabalho, uma abordagem flexível, quanto à utilização dos termos Planejamento e Controle de Produção (PCP), Planejamento e Controle de Produção, Gestão de Produção, Administração da Produção ou Processo de Negócio de Gestão de Produção ${ }^{3}$. A idéia geral é que quando nos referimos a 'Planejar e Controlar a Produção' estamos nos referindo a um processo contido dentro do Processo de Gestão de Produção, na seqüência, partindo do geral para o específico, o processo de 'Planejar e Controlar a Produção' contém outros processos. O trabalho por seu caráter exploratório e descritivo, não tenta neste momento definir limites específicos entre os termos referenciados, até porque são encontradas na literatura diferentes formas de se denominar objetos iguais, da mesma maneira que para autores e práticos, muitas vezes a mesma denominação serve para diferentes fins. Ainda, muitas vezes vamos encontrar sobreposição de

${ }^{3}$ Poderá ser observado, que se optou preferencialmente pela utilização destes termos, contudo ressalto a utilização de termos como Gestão de Operações, Administração da Produção e Gestão de Operações, cada termo ${ }_{2}$ embuti um significado que muitas vezes pode ter o mesmo sentido que utilizo com os termos utilizados neste trabalho, contudo os preteri em função da amplitude de uso destes termos. 
definições, ou seja, o específico de uma denominação genérica encontra-se no campo de dois objetos diferentes.

Um exemplo prático pode ser dado quando utilizamos o termo Planejamento de Capacidade, o que pode estar se referindo ao Planejamento de Curto Prazo, quando é dependente de decisões, tal qual, sequenciar ordens de produção em um determinado equipamento (abordagem típica no campo da Teoria das Restrições e da Pesquisa Operacional), de forma a reduzir os tempos de preparação, ou ainda planejar a utilização de horas-extras (BAUER et al., 1991). Pode-se ainda estar se referindo a Planejamento de Longo Prazo, quando do planejamento da construção de uma nova fábrica (GAITHER \& FRAZIER, 1999; SLACK et al., 1999). Da mesma maneira, muitas vezes encontramos o termo Planejamento de Capacidade fora das atribuições do PCP, pelo menos na forma que encontramos dentro das empresas e, portanto em boa parte da literatura, quando se trata do Planejamento de Longo Prazo (SLACK et al., 1999).

Ainda, um dos problemas encontrados para se fazer qualquer definição na área é que, praticamente não existe um consenso a respeito da terminologia sobre o tema. Vários termos e expressões são freqüentemente utilizados na língua portuguesa, como também em inglês para tratar do mesmo assunto, assim, estes termos, são muitas vezes traduzidos de maneiras diferentes.

O escopo do trabalho, não é o de trabalhar de forma rígida com as definições, mas sim de oferecer uma visão abrangente sobre o objeto de estudo, de forma a construir uma base suficientemente sólida ao desenvolvimento do trabalho.

\subsection{Processo de Gestão da Produção}

Em SLACK et al. (1999) a função produção é definida como responsável pela gestão dos recursos empresarias com fim de se obter serviços e produtos, a 
classificação de processo de negócio dada pela American Productivity \& Quality Center (APQC, 1998), define como o Processo de Negócio Produzir e Distribuir para a Indústria de Manufatura. Este processo então se desdobra em subprocessos responsáveis por aspectos específicos do macro processo de Gestão de Produção, correspondendo cada um, a um conjunto de atividades classificadas diferentemente segundo a literatura básica.

Independentemente do sistema produtivo, da tecnologia de processo e do sistema (Manufacturing Resources Planning - MRP, Just-in-Time- JIT, Optimized Production Technology - OPT, etc.) utilizado na Gestão da Produção, existem algumas atividades que são tradicionalmente inerentes à sua realização (PIRES, 1995). Isso significa que, num nível de complexidade variável, elas sempre se farão necessárias. Essas atividades são:

\section{PROCESSO DE PREVISÃO DE VENDAS/GESTÃO DA CARTEIRA DE}

PEDIDOS - os trabalhos de planejamento se iniciam com os dados iniciais vindos da área de Vendas. Normalmente esses dados dizem respeitos ao que produzir, em quais quantidades e em que prazo eles devem estar concluídos. Normalmente é fortemente influenciado pelas decisões de alto nível, pelo processo de gestão de demanda e pelo tipo de interação entre o mercado e a empresa.

PLANEJAMENTO AGREGADO DA PRODUÇÃO - consiste no estabelecimento dos níveis gerais de produção e capacidade, para um período de médio/longo prazo, normalmente especificado em termos de famílias de produtos. Nesse nível de planejamento, uma comparação da carga de trabalho com a capacidade, em termos macro, permite antecipar a tomada de decisões, tais como novos investimentos em ativos fixos e novas plantas, quando o tipo de processo e produto permitem, ou outros ajustes, de caráter mais pontual, de forma a atender de melhor forma possível os objetivos de produção. É caracterizado como o ponto 
intermediário do processo de Sales and Operations Planning (Planejamento de Vendas e Operações), o qual CORREA et al. (1997) situam o início nos processos de Gestão da Demanda e Previsão de Vendas, culminando no Plano Mestre de Produção, comumente chamado de MPS (do inglês Master Production Scheduling).

PLANO MESTRE DE PRODUÇÃO - consiste num referencial básico para a produção, estabelecendo quando e em que quantidade cada produto deverá ser produzido dentro de um certo horizonte de planejamento. Na elaboração desse programa, as restrições impostas pela capacidade são verificadas em um nível ainda aproximado, porém como o plano já considera a produção de itens específicos e não famílias ou linhas de produto, como no planejamento agregado, pode-se fazer verificações pontuais como a carga em gargalos produtivos, análises mais detalhadas da capacidade são inviabilizadas por restrições organizacionais e/ou econômicas.

PLANEJAMENTO DAS NECESSIDADES DE MATERIAIS - consiste no planejamento das chamadas necessidades líquidas para cada produto/componente a ser produzido. Essas necessidades líquidas são calculadas com base nas necessidades brutas vindas da lista de materiais, pelas exigências impostas pelo programa mestre e pelas informações vindas do controle de estoques (itens em estoque e itens em processo de fabricação/compras).

CONTROLE DE ESTOQUES - trata basicamente do controle físico sobre todos os itens fabricados, comprados e utilizados pela indústria para a produção de seus produtos. O controle de estoques visa trabalhar com dois objetivos aparentemente conflitantes: minimizar os investimentos em estoques e maximizar os níveis de atendimento aos clientes e produção da indústria.

PROGRAMAÇÃo DA PRODUÇÃo - consiste em definir os prazos de entrega para os itens definidos, respectivamente como fabricados e comprados. 
Para os itens fabricados, muitas vezes são definidos também o centro produtivo e a seqüência das operações a serem realizadas. As restrições a essa tarefa são impostas pela capacidade disponível do centro produtivo, para o período em questão, bem como pelas exigências tecnológicas colocadas nos roteiros de produção.

PLANEJAMENTO E CONTROLE DA CAPACIDADE - estipula quais devem ser os níveis de produção máximos que os centros produtivos devem ter num certo horizonte de planejamento. Cuida das providências para que a capacidade planejada seja realizada e das informações a serem utilizadas por outras atividades do PCP.

CONTROLE DA PRODUÇÃO - consiste em acompanhar a fabricação e compra dos itens planejados (programados), com o objetivo de que os prazos sejam cumpridos. O controle da produção costuma também atuar colhendo dados importantes para o sistema de custos, tomando decisões típicas de chão-de-fábrica (como mudanças de prioridades, necessidade de hora extras, etc...) e alimentando informações ao controle de estoques.

Pertinente ao processo de Gestão de Produção, que agora, diferentemente da visão tradicional que abordava a produção como uma função administrativa do negócio de uma maneira fracionada e departamental, é de central importância a abordagem como um processo, das atividades comumente chamadas de Planejamento e Controle da Produção. Tal nomenclatura então acaba por ser abarcada pelo o quê agora chamamos Gestão da Produção. Podemos então, também tentar definir o processo de Gestão da Produção, de uma maneira geral, como o conjunto de atividades que deve ter a capacidade de desempenhar as seguintes atividades (CORREA et al., 1997) : 
$\checkmark$ Planejamento das necessidades futuras de capacidade produtiva da organização;

$\checkmark$ Planejamento dos materiais comprados;

$\checkmark$ Planejamento dos níveis adequados de estoques de matérias-primas, semi-acabados e produtos finais, nos pontos certos;

$\checkmark$ Programação das atividades de produção para garantir que os recursos produtivos envolvidos estejam sendo utilizados, em cada momento, nas atividades certas e prioritárias;

$\checkmark$ Capacidade de informar corretamente a respeito da situação corrente dos recursos (pessoas, equipamentos, instalações e materiais) e das ordens (de compra e de produção);

$\checkmark$ Capacidade de reagir eficazmente.

Temos assim, uma diversidade de atividades, que essencialmente consistem da tomada de decisões em face de eventos previstos no futuro, portanto é preciso que a empresa planeje antecipadamente as suas operações, de forma que seus objetivos sejam atingidos, garantindo uma sincronia, entre suas operações e o corpo estratégico da empresa como um todo. Assim tenta-se garantir que se atinja os objetivos da corporação, segundo suas metas de eficiência e eficácia. Este processo de gestão, então interfaceia-se com outras funções da companhia, necessitando assim estar integrado a este escopo de funções, na busca de uma eficiência global e não apenas setorizada, como imperava no passado (LUMMUS et al.,1998). 


\subsection{Integração do Planejamento e outras funções empresarias}

CHIAVENATTO (1991), apresenta um exemplo simples e ilustrativo do fluxo de informação e interações entre o planejamento de produção e as demais áreas da empresa, em uma empresa de manufatura:

Com a área de Engenharia Industrial ou Processos: o PCP programa o funcionamento de máquinas e equipamentos e se baseia em Roteiros de Produção fornecidos pela Engenharia Industrial;

Com a área de Suprimentos e Compras: o PCP programa materiais e matérias-primas que devem ser obtidos no mercado fornecedor através do órgão de compras e estocados pelo órgão de Suprimentos. Assim as áreas de Suprimentos e Compras funcionam com base naquilo que é planejado pelo PCP.

Com a área de Recursos Humanos: o PCP programa a atividade da mãode-obra, estabelecendo a quantidade de pessoas que devem trabalhar no processo de produção. O recrutamento, a seleção o treinamento do pessoal são atividades estabelecidas em função do PCP.

Com a área Financeira: o PCP se baseia nos cálculos financeiros fornecidos pela área financeira para estabelecer os níveis ótimos de estoques de matériasprimas e produtos acabados, além dos lotes econômicos de produção.

Com a área de Vendas: o PCP se baseia na previsão de vendas fornecida pela área de Vendas para elaborar o Plano de Produção da empresa e planejar a quantidade de produtos acabados necessária para suprir as entregas aos clientes.

Com a área de Produção: o PCP planeja e controla a atividade da área de produção. 


\subsection{Hierarquia de Planejamento}

Segundo GATHER \& FRAZIER (1999), o planejamento e controle de produção é distribuído segundo uma estrutura hierárquica, Figura 4, onde apresenta a seguinte estruturação:

$\checkmark$ Planejamento da Capacidade de Longo Prazo. Que trata dos seguintes tipos de decisões: planejamento de Instalações (localizações de fábricas, layouts, tamanho e capacidades); planejamento da cadeia de suprimentos e forma de integração; planejamento de processos produtivos (novas tecnologias de produção, novos processos e novos sistemas de automação).

$\checkmark$ Planejamento Agregado: planejamento do nível de utilização de mão-de-obra; planejamento do nível de estoques; planejamento da fábrica; planejamento das instalações; planejamento dos contratos de fornecimento.

$\checkmark$ Planejamento dos Programas Mestres de Produção: desenvolvimento dos planos de produção de produtos.

$\checkmark$ Sistemas de Planejamento de Produção: Sistemas de Estoque de Reserva (Gerência por Pontos de Reposição); Sistemas Empurrados (do tipo Kanban); Sistemas Puxados (MRP) e Sistemas concentrados em Gargalos. 


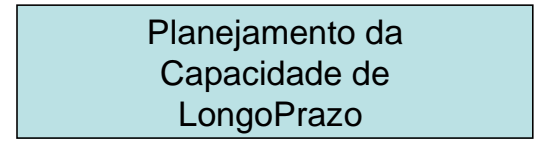

Capacidade de

Longo Prazo

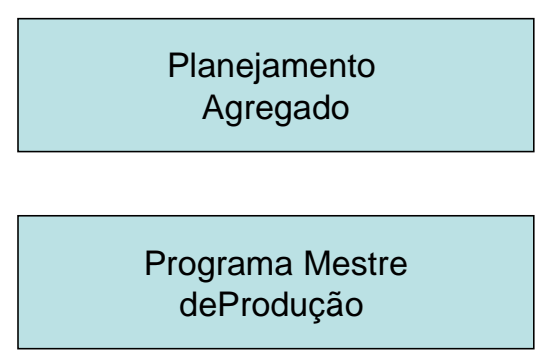

Sistemas de Planejamento

e Controle da Produção

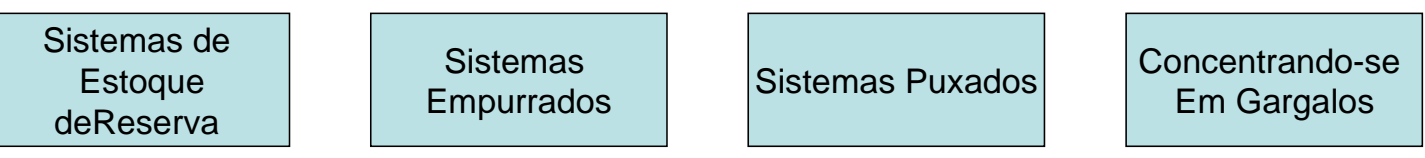

FIGURA 4 - Estrutura do Planejamento de Produção na Manufatura

Adaptado de GAITHER \& FRAZIER (2001)

Das abordagens para sistemas de Planejamento e Controle da Produção, a mais utilizada, é a abordagem hierárquica, que leva em consideração os diferentes horizontes de tempo para os quais se planeja, ainda segundo CHIAVENATTO (1991), pode se dividir em quatro horizontes de tempo, para os quais correspondem diferentes tipos de decisões e tarefas de planejamento, os quais são respectivamente:

$\checkmark \quad$ Nível de planejamento de longo prazo;

$\checkmark \quad$ Nível de planejamento de médio prazo;

$\checkmark \quad$ Nível de planejamento de curto prazo;

$\checkmark \quad$ Nível de planejamento de curtíssimo prazo. 
Tal divisão é bastante subjetiva, sendo suas fronteiras relativas, de um nível em relação ao outro, sendo razoavelmente arbitrária a divisão entre estes níveis de planejamento, dependendo a estrutura de um sistema de planejamento das características dos sistemas de produção e dos contextos ambientais que influenciam as operações de determinada organização (PORTER et al., 1999), contudo tal divisão é uma tentativa de separar atividades e localizar as ações de tomada de decisão, de maneira apropriada ao nível de incertezas e importância destas decisões em cada nível de planejamento. Desta forma, também podemos dizer que as esferas gerenciais onde são tomadas as decisões de cada nível, e o grau de agregação das informações, alteram-se substancialmente, de maior para menor nível hierárquico, quando caminhamos de um nível de decisão de planejamento de longo prazo para os de mais curto prazo (SLACK et al., 1999)

É possível então, criar uma tabela com os tipos de informações de entrada e de saída que temos para cada nível de planejamento, segundo seu horizonte de planejamento:

TABELA 1 - Decisões no Planejamento de Produção

Adaptado de CONTADOR (1997)

\begin{tabular}{|c|l|l|l|}
\hline Horizonte & \multicolumn{1}{|c|}{ Entradas } & Função de PCP & \multicolumn{1}{c|}{ Saídas } \\
\hline Longo Prazo & $\begin{array}{l}\text { Pesquisa de } \\
\text { Mercado } \\
\text { Previsões de longo } \\
\text { prazo }\end{array}$ & $\begin{array}{l}\text { Planejamento de } \\
\text { Recursos }\end{array}$ & $\begin{array}{l}\text { Linhas de } \\
\text { produtos } \\
\text { Processos de } \\
\text { Fabricação }\end{array}$ \\
COMO PRODUZIR & $\begin{array}{l}\text { Políticas de } \\
\text { atendimento ao } \\
\text { cliente }\end{array}$ \\
\hline
\end{tabular}




\begin{tabular}{|c|c|c|c|}
\hline Médio Prazo & $\begin{array}{l}\text { - Previsões de } \\
\text { Demanda de médio } \\
\text { prazo } \\
\text { - Planos de } \\
\text { utilização de mão- } \\
\text { de-obra }\end{array}$ & $\begin{array}{l}\text { Plano de Produção } \\
\text { O QUE E QUANTO } \\
\text { PRODUZIR }\end{array}$ & $\begin{array}{l}\text { - } \text { Necessidades de } \\
\text { materiais } \\
\text { - Planos de } \\
\text { Estocagem } \\
\text { - Planos de Entrega } \\
\text { - Níveis de } \\
\text { utilização de mão- } \\
\text { de-obra }\end{array}$ \\
\hline Curto Prazo & $\begin{array}{l}\text { - } \text { Prazos de Entrega } \\
\text { - } \quad \text { Prioridade de } \\
\text { Atendimento }\end{array}$ & $\begin{array}{l}\text { Programação da } \\
\text { produção } \\
\\
\text { QUANDO } \\
\text { PRODUZIR }\end{array}$ & $\begin{array}{ll}\text { - } & \text { Ordens de } \\
\text { fabricação } \\
\text { - } & \text { Tamanho de } \\
& \text { Lotes } \\
\text { - } & \text { Utilização de } \\
& \text { Horas-Extras }\end{array}$ \\
\hline Curtíssimo Prazo & $\begin{array}{l}\text { - } \text { Ordens de } \\
\text { Fabricação } \\
\text { - } \quad \text { Critérios de } \\
\text { sequenciamento }\end{array}$ & $\begin{array}{l}\text { Liberação da } \\
\text { Produção } \\
\\
\text { ONDE E QUEM } \\
\text { PRODUZIR }\end{array}$ & $\begin{array}{ll}\text { - } & \text { Seqüência de } \\
\text { Tarefas } \\
\text { - } & \text { Requisição de } \\
\text { Recurso } \\
\text { - } \\
\text { Designação de } \\
\text { tarefas } \\
\text { - } \quad \text { Coleta de Dados } \\
\text { para Controle }\end{array}$ \\
\hline
\end{tabular}

\subsection{Sistemas e Filosofias de Gestão da Produção}

\subsubsection{Classificação de Sistemas de Manufatura}

De PORTER et al. (1999) temos que o objetivo da Classificação de Sistemas de manufatura é o de possibilitar melhor entendimento dos sistemas de manufatura, dos processos contidos nestes tipos de sistemas, suas restrições e seus controles, relacionando estas classes com seus respectivos sistemas de controle de produção e fatores condicionantes do ambiente em que se contextualizam.

Segundo PORTER et al. (1999) a validade de um método prover modelos de referência de melhores práticas (best practices) e melhor adequação (através de um sistema de classificação de manufatura) aos sistemas de manufatura é em si mesmo bastante limitada. Os condicionantes que nos fazem definir estas "melhores 
práticas" estão naturalmente no passado e mostram que construímos as definições de melhores práticas baseados no desempenho histórico positivo das empresas que criaram estas melhores práticas. Contudo a análise destas práticas é valiosa para as organizações menos estruturadas a atingirem os níveis de empresas de sua classe. O resultado da identificação das melhores práticas tem por fim o de nivelar o conhecimento das organizações sobre estas práticas, tornando-as fatores não mais distintivos no alcance de uma fonte de vantagem competitiva.

Concretamente a inovação consiste na principal fonte de vantagem competitiva. Assim uma inovação deve ser algo radicalmente novo, tanto uma idéia nova quanto um avanço tecnológico, mas na prática a inovação tem consistido em adaptações de idéia e práticas comuns em uma determinada área, que são aplicadas e adaptadas em outra. Neste caso, o que torna distintivo em uma prática é a identificação pioneira desta oportunidade de adaptação desta prática para um novo setor.

PORTER et al. (1999), enumera então algumas tipologias de classificação de manufatura:

Classificação de Manufatura segundo a perspectiva de continuidade $e$ estabilidade, classificando a manufatura segundo um espectro discreto-contínuo. Nesta forma de classificação a manufatura é tratada em um continuum, onde de um lado está a manufatura discreta e no extremo oposto à manufatura contínua de processo (Ex: Manufatura de Processos Químicos, como uma refinaria de petróleo). Esta classificação é normalmente relacionada com as escalas de produção e com o grau de variedade de produtos finais.

Dentro desta topologia temos então a seguinte classificação. Manufatura job shop: produção caracterizada pela produção em baixos volumes, muitas vezes de produtos únicos, com demanda bastante difícil de ser prevista. A análise de 
capacidade é caracteristicamente difícil, pois o mix de produção pode variar bastante. Os roteiros produtivos neste tipo de manufatura acabam por ser grande importância, pois os baixos volumes acabam por colocar um alto grau de variação nos processos, sendo normalmente o layout produtivo funcional, a mão-de-obra altamente especializada e processo produtivo sendo bastante flexível (VOLLMANN et al., 1997). Exemplos são a indústria de roupas de alta costura e a manufatura de máquinas e equipamentos. Manufatura de Processo: tipo de manufatura que é caracterizado pelo grande volume de produção de um pequeno número de produtos padrão. A demanda no curto e médio prazo é estável e as mudanças de projeto durante o ciclo de vida do produto é pequena. O grau de habilidade da mão-de-obra é menor do que na manufatura job-shop e um exemplo deste tipo de manufatura é o da indústria automotiva. Produção por Lotes: situa-se entre a manufatura job shop e manufatura de processo, sendo caracterizada pelos pequenos e médios volumes de produção e um número de produtos finais também intermediário. PORTER et al. (1999) caracteriza este tipo de produção pelo fato que os lotes de produção são normalmente produzidos também de maneira discreta, ou seja, um lote só passa para o processo seguinte após que todo o lote tenha sido processado.

Produção por Projetos ou Complexa: pelo seu caráter único, se assemelha a manufatura job shop, contudo pelo porte, pela exclusividade e por ser normalmente feita no lugar onde será consumida, merece uma classificação própria. Normalmente se serve de produtos que são feitos com outras características de produção e os grandes problemas deste tipo de manufatura é de atender as características do cliente, no prazo certo e com lucratividade.

PORTER et al. (1999) ainda apresenta uma classificação que segue o modelo apresentado em VOLLMANN et al. (1997), de classificação da manufatura, segundo o ponto de contato entre o processo produtivo e demanda: MTO (Make-to- 
Stock), produção para estoques, ocorre quando a demanda real não afeta o processo produtivo diretamente e o planejamento é feito essencialmente baseado em previsões; ATO (Assemble-to-Order) montagem contra pedido, manufatura onde componentes são feitos segundo previsões e os produtos finais são montados essencialmente contra pedidos, típica de ambientes JIT (Just-in-Time), são dependentes de um projeto do produto que permita esta configuração, que permite uma maior segurança frente a variedade da demanda pelo produto final. MTO (Make-to-Order), produção de produtos padronizados frente a pedidos. ETO (Engineering-to-Order), manufatura onde um produto com características básicas é oferecido, contudo há um grande grau de customização e modificações é possível. DTO (Design-to-Order), uma área de conhecimento é ofertada, assim o produto é projetado e desenvolvido segundo os requisitos do cliente, com características únicas e longos tempos de processamento.

\subsubsection{MRP}

A sigla MRP, designou inicialmente Materials Requirement Planning, ou seja, Planejamento da Necessidade de Materiais, e sua conceituação definitiva aparece no trabalho de Orlicky em 1975, "Materials Requirement Planning”, onde é apresentado a lógica de Planejamento de Produção, essencialmente baseada na gestão de estoques e de tempo, vindo a ser a técnica de planejamento de produção básica na manufatura, suplantando as técnicas anteriores (ainda utilizadas em paralelo, com as filosofias e práticas atuais) que se baseavam no planejamento e definição de níveis de estoque, periodicidade de controle e de lotes de produção/reposição (VOLLMANN et al., 1997; BROWNE et al., 1988).

A lógica adotada no MRP é basicamente simples, onde se baseando em uma Estrutura do Produto, onde cada produto possuí uma lista de materiais que o compõem, calcula-se as necessidades de materiais (tanto comprados quanto 
fabricados) em um determinado momento (baseado no Lead-Time, que em português podemos traduzir por tempo de obtenção ou fornecimento), para que se cumpram os programas de entrega de produtos, com um mínimo de estoques.

As limitações quanto a considerações de capacidade da lógica MRP, dão origem à oportunidade do surgimento do MRP II (Manufacturing Resources Planning - Planejamento dos Recursos de Manufatura), onde são embutidas funcionalidades que permitem o suporte à análise da capacidade, através da inclusão de tempos de processo, através da utilização de roteiros de produção. Assim são adicionados ao MRP I, as funções de Programação Mestre da Produção (MPS - Master Planning Scheduling), Cálculo Grosseiro das Necessidades de Capacidade (RCCP - Rough Cut Capacity Planning), Cálculo da Necessidade de Capacidade (CRP - Capacity Requirement Planning), Controle de Chão-de-fábrica (SFC - Shop Floor Control - Controle de Chão-de-Fábrica ou PAC - Production Activity Control - Controle de Atividades de Produção) e integração aos sistemas MRP a função de Compras, caracterizando a extensão dos conceitos do então passou-se a denominar MRP I, de forma a ampliar a interação entre os diversos setores da fábrica. 


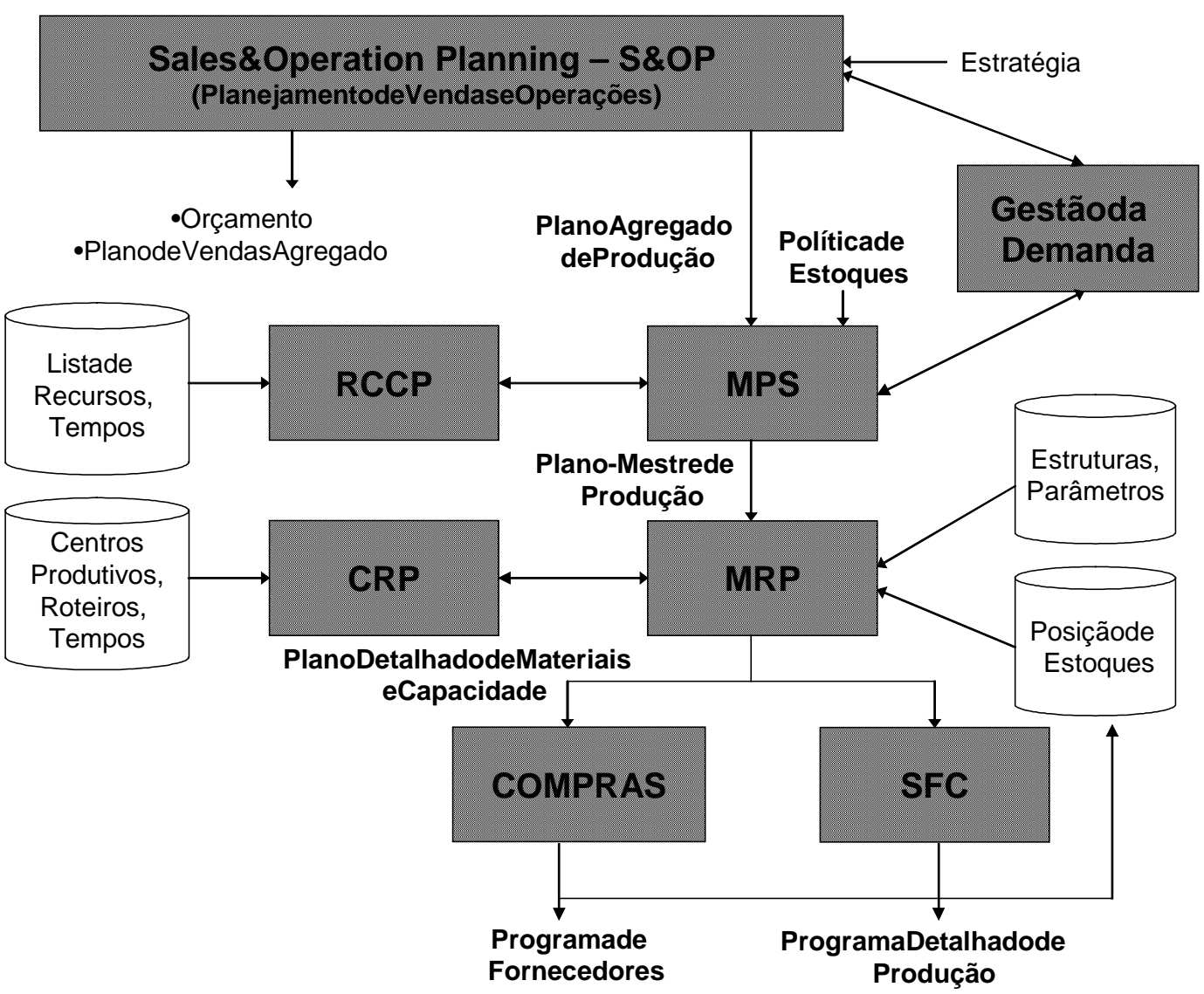

FIGURA 5 - Esquema de Processamento MRP

Adaptado de CORREA et al. (1997)

O sistema MRP II tem um procedimento hierárquico, com ciclos de realimentação, onde problemas detectados em níveis de planejamento inferiores, realimentam novas tentativas de adequação de níveis superiores, além disto o módulo de Controle de Chão-de-Fábrica proporciona um feedback das posições das Ordens de Produção em andamento, o mesmo quanto ao módulo de compras e as requisições de estoque.

Há a necessidade de os usuários definirem uma série de parâmetros de operação para o MRP II, que vão condicionar a forma com que o sistema vai planejar a produção e também condicionar a adequação do sistema MRP II ao sistema de produção em que ele se encontre instalado. Alguns desses parâmetros 
são: tamanhos de lotes, níveis de estoque de segurança e tempos de segurança para os diversos itens, formas de processamento, período e horizontes de planejamento, entre outros. É central para seu bom funcionamento que os usuários entendam as variáveis envolvidas na definição destes parâmetros e que os definam de forma adequada, sob pena de sérios prejuízos ao desempenho do sistema (CORREA et al., 1997).

O trabalho de Orlicky, ensejou uma nova dimensão que revolucionou o planejamento de produção à sua época, os pontos de destaque que fizeram a lógica MRP se destacar frente ao planejamento de estoques, que constituía na principal ferramenta de gestão de produção vigente, foram (BROWNE et al., 1988):

$\checkmark$ Reconheceu a impropriedade da gestão de estoques em tratar demanda dependente e independente da mesma forma;

$\checkmark$ Uma vez que haja uma programação de entrega de itens de montagens, decorre a possibilidade de cálculo de necessidades de entrega de material, segundo um cronograma que pode ser calculado, portanto não faz sentido fazer previsões de demanda para estes itens;

$\checkmark$ As suposições implícitas nos modelos de controle de inventário, levam em conta uma demanda uniforme ou pelo menos bem definida. Contudo a dependência da demanda de componentes da demanda de itens de nível mais alto, dá ensejo ao aparecimento de descontinuidades de demanda, devido a política de lotes mínimos;

$\checkmark$ advento do computador criou a possibilidade de se executar os cálculos necessários eficientemente.

As características principais da lógica dos sistemas MRP segundo BROWNE et al. (1988):, são: 
$\checkmark$ É orientado ao produto, porque opera com base em listas de materiais;

$\checkmark$ É orientado para o futuro, porque utiliza as informações do MPS para calcular as necessidades de material, ao invés de utilizar-se de previsões;

$\checkmark$ Envolve time phased requirement durante o processamento, ou seja, dispõem as necessidades de material em função dos tempos de processamento e obtenção esperados (lead-time);

$\checkmark$ Envolve planejamento de prioridades, pois estabelece o que necessita ser feito para atender o plano mestre de produção e não o quê pode ser feito;

$\checkmark$ Promove o controle através do foco nas ordens, sejam de compra ou de fabricação.

O advento do MRP é de importância fundamental no estudo do planejamento de produção, podemos afirmar que seu surgimento e sistematização posterior, revolucionaram o planejamento de produção. Sua lógica simples e intuitiva, tornou-se aplicável através do computador para corporações que lidam com uma quantidade enorme de itens, significando enorme avanço frente às práticas existentes.

Sua popularização nos Estados Unidos durante a década de 70, foi suportada fortemente pela APIC'S (American Production and Inventory Control Society) (LAURINDO \& MESQUITA, 2000), criando-se uma legião de consultores, movidos por uma fé inabalável em seus resultados e pela indústria de informática ávida pela utilização de seus produtos (BROWNE et al., 1988). Ressalte-se que um dos principais motivos de sua popularização foi seu caráter integrador das funções ligadas a manufatura, como a engenharia, compras e produção, estando seu atrativo não somente no seu conteúdo de sistema de apoio a decisão mas ao seu caráter integrador. 


\subsubsection{JIT (Just in Time)}

O sistema Just-in-Time (JIT) é definido como uma filosofia de manufatura (BAUER et al., 1991; CORREA \& GIANESI, 1993; SLACK et al., 1999), de modo geral consistindo em três elementos básicos: um sistema de gerenciamento da produção, um sistema de garantia da qualidade, e um sistema de manutenção preventiva total. De modo geral, os objetivos da filosofia JIT, modernamente também chamado de Sistema Toyota de Produção (WOMACK \& JONES, 1998; ALVAREZ \& ANTUNES JR, 2001) é o de reduzir os desperdícios, minimizando elementos e atividades que não agregam valor ao produto, como por exemplo: retrabalho, estoques intermediários e tempos improdutivos. Sob a ótica JIT, a produção deve ser na quantidade e datas necessárias para uso imediato, ou seja, nem mais, nem menos; nem antes, nem depois.

De modo resumido os elementos que devem compor a implementação de um sistema JIT são:

$\checkmark$ reduções dos tempos de preparação de máquinas, para viabilizar a produção de lotes mínimos. Em um sistema JIT, a meta de lote de produção ideal é igual a uma unidade do produto;

$\checkmark$ utilização de Tecnologia de Grupo e de arranjos físicos celulares;

$\checkmark$ utilização de sistemas de manutenção preventiva;

$\checkmark$ utilização de mão-de-obra multifuncional;

$\checkmark$ utilização de cargas de trabalho uniformes e operações padronizadas;

$\checkmark$ sistema de compras JIT, ou seja, receber o item certo, na quantidade certa, no prazo certo e na qualidade certa, com um número mínimo de fornecedores;

$\checkmark$ produção puxada e controlada por sistemas Kanban; 
$\checkmark$ qualidade (conformação) com o objetivo de "zero defeito".

Planejamento em ambiente JIT

O Planejamento em ambiente Just-in-Time dá-se por meio das seguintes técnicas e abordagens (SLACK et al., 1999): Controle Kanban; Programação nivelada; Modelos mesclados e Sincronização.

Kanban é uma ferramenta que consiste de um sistema de controle e planejamento da produção bastante simplificado e descentralizado e que tem como princípio "puxar" a produção, ao invés dos sistemas tradicionais que "empurram" a mesma. Nesse sistema, a área de montagem final é que inicia os processos produtivos, criando assim um processo em cadeia onde os centros produtivos assumem também a responsabilidade de cobrar e buscar os materiais nos centros produtivos que são seus fornecedores.

A operacionalização do Kanban costuma ser feita por um ou dois cartões. $O$ sistema de dois cartões (cartão de transporte e cartão de produção), consiste originalmente no sistema desenvolvido pela Toyota. A maioria das empresas japonesa faz uso de cartão único, que proporciona um mecanismo de controle mais simples, porém mais vulnerável a imprevistos que podem levar a níveis de estoques em processo. 


\section{Programação Nivelada}

A filosofia JIT, utiliza-se largamente do projeto para manufatura e da utilização de projetos modulares, de forma a fazer perceber ao mercado a maior variedade possível de produtos, dentro de um ambiente de manufatura voltado à criação de famílias de produtos, que apresentam uma enorme variação de detalhes, porém através da tecnologia de grupo, e de uma relação produto e processo inteligente, não elevar os custos de produção (BAUER et al., 1991).

A ênfase na redução de tempos de setup proporciona uma grande flexibilidade de produção, dentro dos itens de uma mesma família de produto, então a adequação da produção de demanda se dá pelo processo de nivelamento de produção, que se utiliza dos lead time reduzidos para ajustar a produção a demanda, evitando excessos de produção ou falta de produtos.

A primeira fase adapta a demanda mensal, similar ao processo de MPS (Master Production Schedule), chegando-se a uma taxa de produção diária de um produto, através da previsão de vendas de um determinado produto. Por exemplo, se tenho a previsão de demanda de 500 produtos mês, supondo 20 dias úteis, chego a uma necessidade de uma taxa de produção de 25 itens dias. A segunda fase é chamada de nivelamento diário, onde projeto seqüências de produção que nivelem a produção dos diversos itens dentro do dia. Suponhamos então que necessitamos produzir por dia 60 produtos de $A, 40$ de $B$ e 80 de $C$, ao invés de produzir os lotes inteiros, arranja-se um ciclo de produção nivelado, produzindo por exemplo 20 ciclos diários, produzindo-se 3 unidades de A, 2 de B e 4 de $\mathrm{C}$.

\section{Modelos Mesclados}

O conceito de Modelos Mesclados, está intimamente ligado a produção nivelada, ao objetivo de mínimos tempos de preparação e ao projeto para 
manufatura. O conceito é de que é possível a produção de produtos finais diferentes de maneira simultânea, portanto flutuações na demanda dos produtos dentro de uma faixa estreita, podem ser acomodadas de maneira quase instantânea, através da mudança dos ciclos de produção.

\section{Sincronização}

Sincronização significa ajustar as saídas de cada estágio do processo de produção para garantir as mesmas características de fluxo para cada um dos componentes ou produtos, à medida que eles avançam através de cada estágio do processo produtivo (SLACK et al., 1999). A idéia geral é ajustar as taxas de produção de forma a não permitir que linhas de montagem tenham problemas de abastecimento devido a oscilações de demanda, possibilitando um fluxo contínuo no processo de produção.

Esta técnica também é conhecida como One Piece Flow, onde transferência de materiais entre postos de trabalho se dá em lotes de tamanho igual a uma unidade, utiliza-se aqui do conceito de takt-time, que corresponde a divisão do tempo diário de operação elo número de peças requeridas por dia, para sincronizar a saída de produtos do sistema produtivo, com a demanda diária de produção (ALVAREZ \& ANTUNES JR, 2001).

De modo resumido, algumas mudanças importantes dentro da manufatura causadas pela utilização da filosofia JIT são:

$\checkmark$ colocação do cliente/mercado como pólo norteador da manufatura;

$\checkmark$ diminuição da mão-de-obra indireta no "chão-de-fábrica" e conseqüentemente envolvimento da mão de obra direta nas atividades de controle da produção, controle da qualidade e manutenção preventiva; 
$\checkmark$ mudança na relação com os fornecedores, através de uma relação de desenvolvimento e cooperação de longo prazo;

$\checkmark$ criação da mentalidade de que os tempos improdutivos e estoques devem ser minimizados / eliminados.

\subsubsection{Teoria das Restrições e OPT}

Criado pelo físico Eliyahu M. Goldratt em meados dos anos 80 surge a Teoria das Restrições, através do surgimento do sistema OPT, Optimized Production Technology (SOUZA, 1997), software cujos conceitos básicos popularizados pelo livro A Meta, tomam forma como pensamento sistêmico, ganhando corpo no que se batizou como "Teoria das Restrições", onde se aliam a aplicação de conceitos matemáticos e heurísticos a uma série de preceitos que já haviam aparecidos sob a filosofia Just-in-Time (BROWNE et al., 1988).

A Teoria das Restrições, através do OPT foi inicialmente fundamentada em programas de computação com o objetivo de desenvolver e implementar um sistema de programação de produção com capacidade finita, para resolver problemas de programação de chão-de-fábrica.

Segundo VOLLMANN et al. (1997), os princípios básicos envolvidos no método de programação da produção são:

$\checkmark$ balancear o fluxo e não a capacidade;

$\checkmark$ as restrições determinam o nível de utilização dos centros produtivos não gargalos, ou seja, o nível de utilização de um centro produtivo não gargalo não é determinado pelos seus próprios recurso, mas sim por alguma restrição (gargalo) do sistema; 
$\checkmark$ ativar nem sempre significa utilizar, ou seja, utilizar um recurso, quando sua produção não puder ser absorvida por um recurso gargalo, pode significar perda com a formação de estoques;

$\checkmark$ uma hora de produção perdida no recurso com restrição de capacidade é uma hora perdida em todo o sistema produtivo;

$\checkmark$ uma hora economizada num recurso não restritivo é uma ilusão, visto que não acrescenta a capacidade total do sistema;

$\checkmark$ os recursos gargalos governam o volume de produção e o volume de estoques;

$\checkmark$ os lotes de transferência deveriam ser variáveis, ou seja, não necessariamente iguais aos lotes de produção;

$\checkmark$ os lotes de produção deveriam ser variáveis, ou seja, deveriam atender apenas às necessidades imediatas (como o JIT);

$\checkmark$ a programação da produção deveria ser estabelecida examinando-se simultaneamente todas as restrições do sistema produtivo. Lead times são resultado da programação e não podem ser preestabelecidos.

Desse modo algumas importantes características do sistema OPT são (CORREA \& GIANESI, 1993): procurar maximizar o volume de produção (output) do sistema produtivo global; pode ser utilizado tanto em indústrias com um mix limitado de produtos, como por outras que produzem sob encomendas; considera somente os recursos com restrição de capacidade nas simulações realizadas.

Segundo SOUZA (1997), para a Teoria das Restrições, restrição é qualquer coisa que limita um sistema em conseguir maior desempenho em relação a sua meta. Utilizando-se da analogia da corrente, restrição seria o elo mais fraco. Pode- 
se afirmar, devido às flutuações estatísticas presentes, que todo sistema possui pelo menos uma restrição.

Podem existir diversos tipos de restrições. Estas podem ser físicas, como uma máquina com baixa capacidade produtiva, despreparo ou baixo número de empregados, ou então restrições não físicas, como as restrições de política da empresa, comportamentais, culturais ou de mercado (SOUZA, 1997).

Ainda segundo GOLDRATT \& COX (1993), toda organização é formada ou constituída com um propósito principal e que este é, na verdade, determinado por seus proprietários ou por seus acionistas, que investem recursos com um determinado objetivo. Se a empresa possui ações negociadas no mercado de capitais, certamente a meta é "ganhar mais dinheiro tanto agora como no futuro".

Definido o objetivo, a empresa deve agora encontrar as medidas necessárias para guiar e controlar seus esforços na direção de sua meta. Segundo SOUZA (1997), para a aplicação da Teoria das Restrições, as medidas financeiras são necessárias por dois motivos principais. A primeira é controle, ou seja, saber até que ponto a empresa está conseguindo alcançar o objetivo de gerar dinheiro. A outra razão, e talvez a mais importante delas, é induzir que as partes façam o que é bom para a organização como um todo. Tradicionalmente, são usadas três medidas para se avaliar a "saúde" das empresas: o lucro líquido (medida absoluta), o retorno sobre o investimento (medida relativa) e o fluxo de caixa (condição necessária muito importante à sobrevivência da companhia). Estas, quando julgadas em conjunto, são suficientes para fornecer as informações financeiras necessárias à administração de uma empresa.

O uso destas medidas, porém, são muito úteis nos relatórios da alta cúpula administrativa, mas dizem muito pouco quando se pretende medir o impacto das ações locais no resultado global do sistema. Assim, a Teoria das Restrições definiu 
três novos elementos que não apenas auxiliam nas tomadas de decisões da diretoria da empresa, como também nas decisões operacionais locais. São eles:

Ganho (Throughput) : índice pelo qual o sistema gera dinheiro através das vendas.

É importante observar na definição que o ganho só é obtido quando o produto (ou serviço) é efetivamente vendido. Desta forma evita-se qualquer confusão entre produção e ganho. Se o que foi produzido não for realmente vendido não se obtém ganho.

Inventário (Inventory) : todo o dinheiro que o sistema investe na compra de coisas que pretende vender.

Aqui, inventário deve ser entendido no seu sentido mais amplo, incluindo máquinas, equipamentos, instalações, construções, materiais, etc.. Esta definição é a mesma do convencional significado de ativo, com exceção ao que se refere ao inventário de material. A Teoria das Restrições propugna que não se deve atribuir valor ao produto conforme este vai sendo manipulado pelo sistema produtivo, uma vez que todo conceito de valor acrescido ao produto faz parte de um distorcido processo de otimização local. O objetivo é acrescentar valor à empresa e não ao produto (SOUZA, 1997).

O fato de não se levar em conta no cálculo do inventário o valor agregado ao mesmo, contrariando as práticas de custeio tradicional, não significa que a consideração destas despesas seja descartada. Tais gastos, para ele, aparecem na terceira medida denominada Despesa Operacional.

Despesa Operacional (Operating Expenses) : todo o dinheiro que 0 sistema gasta transformando Inventário em Ganho. 
Despesa Operacional pode ser entendida, portanto, como todo dinheiro que sai ou é perdido pelo sistema.

SOUZA (1997) menciona que Goldratt passou a adotar, no início de 1987, o nome atual teoria das restrições. Para ele, um melhor entendimento da psicologia provocou nele uma mudança da ênfase em regras e princípio para um foco em um processo iterativo. Além disso, as significativas ramificações que este processo teve para áreas como contabilidade, distribuição, marketing e projeto do produto quase o forçou aquela escolha de palavras.

Pode-se dizer, que a Teoria das Restrições se divide hoje em três grandes grupos de atuação: os diagramas de causa-e-efeito denominados de Processos de Raciocínio com suas cinco ferramentas fundamentais (árvore da realidade atual, diagrama de dispersão de nuvem, árvore da realidade futura, árvore de prérequisitos e árvore de transição), o uso das definições ganho, inventário e despesa operacional como norteadores para tomadas de decisões e seus aplicativos em gerenciamento de distribuição, marketing, gerenciamento de projetos (denominado Corrente Crítica), o método Tambor-Pulmão-Corda, entre outros.

Segundo alguns críticos, o sistema OPT, que precedeu o aparecimento da Teoria das Restrições, não acrescenta nada de novo à tradicional técnica de Programação Linear. Segundo VOLLMANN et al. (1993), não é um sistema de resultados ótimos, mas heurístico, cujo desempenho depende pelo menos dos seguintes fatores:

$\checkmark$ do percentual de recursos com restrição de capacidade existente;

$\checkmark$ da quantidade de recursos ou centro produtivos existentes;

$\checkmark$ do tamanho da estrutura dos produtos;

$\checkmark$ do nível de detalhamento dos arquivos de roteiro de produção. 
Ainda segundo VOLLMANN et al. (1997), o OPT procura compatibilizar na sua função objetivo questões tidas como antagônicas, tais como minimizar custo e maximizar o desempenho das entregas.

\subsubsection{A Gestão da Cadeia de Suprimentos, os Sistemas APS e os novos desafios do Planejamento de Produção}

Dentre a busca por novos nichos onde se possa obter vantagem competitiva, uma das tendências aponta para a emergência de técnicas de Supply Chain Management (SCM), acompanhadas pelo surgimento de novas ferramentas que suportam a sua implementação e uso. No que tange à gestão de operações, tais ferramentas disponibilizam funcionalidades tais como: Programação da Produção, Análise de Disponibilidade para Compromisso de Entrega, Planejamento da Rede de Suprimentos. Portanto, tem-se a perspectiva de uma utilização mais efetiva dos sistemas para programação finita da produção e que possam ser utilizados de maneira dinâmica e flexível. Para isso necessita-se de informações que sejam precisas, consistentes e atuais eliminando a necessidade de apontamentos e minimizando os erros inerentes ao processo manual. Como resultado, possibilita-se que o SCM dê-se sobre dados reais e atualizados, evitando que se repitam às incongruências comuns na implementação de softwares para a gestão da produção, que é a implementação e operação baseada em dados imprecisos e pouco confiáveis.

A busca por uma maior competitividade é a tônica geral das empresas, que estão expostas a um ambiente de grandes mudanças guindadas por uma crescente abertura dos mercados nacionais, que expõe as empresas em geral e principalmente as empresas de manufatura, a uma concorrência virtualmente global, além disto a revolução tecnológica, característica do momento histórico 
atual, aumentou de forma incrível o grau de incerteza do horizonte de planejamento empresarial.

Segundo PIRES (1998), monta-se assim um cenário onde as empresas buscam novas práticas empresariais, que possam Ihes disponibilizar um incremento de seu diferencial competitivo. Após a emergência de uma grande série de práticas, filosofias e tecnologias, presenciadas durante os últimos anos, vislumbra-se a emergência da busca de novas vantagens competitivas através do gerenciamento e sincronização da Cadeia de Suprimentos, corporificado na filosofia de Gestão da Cadeia de Suprimentos, em inglês "Supply Chain Management". Tal filosofia vem embasada num conjunto de pressupostos e práticas, que visam à integração e parceria das empresas ("elos" da cadeia), e também no desenvolvimento da tecnologia da informação, que proporciona o surgimento de ferramentas que suportem o gerenciamento da Cadeia de Suprimentos, através da troca de informações entre os participantes da cadeia.

O objetivo da Gestão da Cadeia de Suprimentos pode ser definido como “... o desenvolvimento de sinergia por toda a cadeia de suprimentos, do fornecedor do fornecedor ao cliente do cliente e assim até o consumidor final” (VOLLMANN et al., 1997), cuja efetividade deve ser avaliada em termos de custos e aumento do valor percebido de bens e serviços de bens e serviços oferecidos ao consumidor final.

Desta forma as fronteiras do planejamento de produção extrapolam os limites da empresa, o que tem ensejado o forte ressurgimento da utilização de softwares e técnicas de programação controle da produção que utilizam a lógica de programação finita, pois embora as técnicas de pesquisa operacional sejam estudadas desde o começo da década de 50, e haja softwares para programação finita da produção disponíveis desde os anos 70, o enorme aumento da capacidade de processamento de dados (CORREA et al., 1997) e o desenvolvimento das 
técnicas de coleta de dados deram um novo impulso às técnicas de programação de produção com suporte computacional. Pois a capacidade de processamento tem sido um dos problemas para um bom resultado das técnicas de simulação e pesquisa operacional, aplicadas na programação da produção. Além disto, uma das funcionalidades dos softwares de gestão da Cadeia de Suprimentos, é a sincronização dos membros da Cadeia de Suprimentos, de forma a permitir uma maior flexibilidade e capacidade de entrega, otimizando desta forma os recursos de toda a Cadeia de Suprimentos.

Segundo ALVORD (1999), a otimização da produtividade interna já não é suficiente para um desempenho distintivo da concorrência. A resposta está na integração e sincronização da cadeia de suprimentos, possibilitando seus participantes a cooperarem abertamente para:

$\checkmark$ Diminuir os tempos do fluxo total de produção;

$\checkmark$ Reduzir os estoques da cadeia ao mínimo;

$\checkmark$ Melhorar a qualidade de produto;

$\checkmark$ Fornecer prazos mais confiáveis;

$\checkmark$ Coordenar a demanda global, fornecimento e produção eficientemente;

$\checkmark$ Diminuir os custos gerais da cadeia de suprimentos;

$\checkmark$ Continuamente reavaliar os processos, de forma a ter respostas mais rápidas a clientes e competição

Em LUMMUS et al. (1998), encontramos algumas mudanças na forma como as empresas estão operando na busca de uma maior eficiência na gestão da Cadeia de Suprimentos: compartilhamento das informações entre fornecedores e clientes; processos de negócios horizontais substituindo a departamentalização 
vertical; mudança da produção em massa para a customização em massa; maior dependência de fornecedores de materiais e processos, com simultânea redução no número de fornecedores; grande ênfase na flexibilidade organizacional e de processos; necessidade de coordenar processos distribuídos; "Empowerment" dos funcionários e necessidade de sistemas de suporte a decisão baseados em regras e em tempo real; pressão para a introdução de novos produtos mais rapidamente.

A resposta à complexidade da gestão da manufatura na Cadeia de Suprimentos surge na forma do desenvolvimento das soluções APS (Advanced Plannning and Scheduling - Planejamento e Programação Avançada)(ROWEN, 1999).

O desenvolvimento das soluções APS vem na esteira dos desenvolvimentos nas áreas da ciência computacional e de tecnologia da informação. $O$ desenvolvimento das técnicas de programação da produção, através da lógica baseada em regras, heurísticas, programação linear-mista, redes neurais, algoritmos genéticos, e outras vêm possibilitando o tratamento de centenas variáveis e restrições no ambiente de manufatura, com uma velocidade condizente a dinâmica das operações.

O aparecimento das ferramentas APS, contudo, ainda esbarra no relativo desconhecimento de sua utilização na melhoria de performance da Cadeia de Suprimentos. As soluções APS, na verdade constituem um conjunto de ferramentas e não um simples aplicativo, que vieram a suprir as lacunas dos sistemas de planejamento ERP e MRP (ROWEN, 1999). Estas ferramentas tratam do suporte a gestão e planejamento da demanda, produção, cadeia de fornecedores e distribuição.

ALVORD (1999), aponta para as seguintes tendências na utilização das soluções APS: 


\section{Sincronizar Operações}

Envolve a tarefa de planejar as operações, considerando simultaneamente a gestão de restrições de material e capacidade. Isto exige um planejador de restrições de materiais e capacidade (MCP - Materials and Capacity Planner). Sua função é possibilitar o planejamento e programação da planta, levando em consideração, simultaneamente, restrições, de material, de capacidade e de pedidos.

Um MCP, deve em suma atingir os seguintes requisitos para seu bom funcionamento: habilitar ampla capacidade de modelagem; capacidade de tratar com complexas listas de materiais; suportar pegging; suportar restrições; suportar roteiros complexos; possibilitar análise de Disponibilidade para Entrega e de Capacidade para Compromisso ao nível de planta produtiva; possibilitar análise de simulações de cenários produtivos; identificar recursos com restrição de capacidade (gargalos); garantir uma política de liberação de ordens, que leve a minimização de tempos de espera e maximização da utilização de gargalos; possuir modelos de adequação aos tipos de indústria, de forma a maximizar o tempo de implementação; possuir interface com os sistemas ERP e MRP, garantindo a atualização dos dados de disponibilidade de material; manter constante a viabilidade de planejamento

Por mais detalhado e otimizado que seja feito, o planejamento será sempre sujeito a eventos inesperados, comuns à dinâmica de chão-de-fábrica. Eventos como quebra de máquinas, falta de operador, falta de material, falta de ferramenta, diferenças entre o tempo de processamento previsto e o real, problemas de qualidade, dentre outros, são o que realmente põem à prova a real eficiência de um sistema para controle de chão-de-fábrica. Portanto é fundamental garantir a existência de um monitoramento em tempo real do status das ordens no chão-de- 
fábrica. Deve haver, portanto um mecanismo de avaliação e reação, a estes tipos de eventos, que garanta a consistência do planejamento e lidar com alternativas a estes eventos. Deve existir então um Monitor de Eventos, que controle e reaja aos eventos inesperados que impactem as operações, quanto ao planejado. Tal monitor deve estar integrado aos sistemas MES (Manufacturing Execution System ou Sistemas de Execução de Manufatura) e seus objetivos principais são resumidos por ALVORD (1999) em:

$\checkmark$ Acompanhar a execução dos lotes e proporcionar o status de produção em tempo real e garantir o feed-back dos eventos de chão-de-fábrica;

$\checkmark$ Comparar os dados de processamento real com o planejado, avaliando o impacto e detectar correções na programação se necessário;

$\checkmark$ Reagir aos eventos inesperados, causadores de restrições e sugerir alternativas.

$\checkmark$ Incluir interfaces prontas para integração com uma variedade de sistemas MES (Manufacturing Execution Systems e outros sistemas de chão-defábrica).

$\checkmark$ Eliminar Gargalos

Manter o máximo fluxo de produção, exige um sistema que possa realizar um detalhado sequenciamento de operações, sincronização da programação da produção e a otimização dos recursos de chão-de-fábrica. Necessariamente deve ser suportado por um mecanismo que proporcione uma análise em tempo real do status do chão-de-fábrica. Este mecanismo é definido por ALVORD (1999), como um programador dinâmico. 
O papel das ferramentas APS, na gestão da Cadeia de Suprimentos exige uma ferramenta que permita a coleta e tratamento em tempo real dos dados de produção.

Além disto, podemos dizer que as implicações da gestão da Cadeia de Suprimentos na produção se estendem na direção de uma maior preocupação de otimização dos fluxos entre os "elos" da cadeia, esbarrando assim na abordagem dos tradicionais sistemas de planejamento da produção (VOLLMANN et al., 1997), que estão mais focados numa abordagem discreta da produção, o que torna-se crítico no caso do MRP.

\subsection{Considerações sobre o Planejamento de Produção e a coleta automatizada de dados de produção}

O sistema/lógica MRP é a arquitetura dominante para os Sistemas de Planejamento e Controle de Produção. Tal sucesso pode ser justificado pela simplicidade de sua lógica, quase intuitiva e pelo atendimento aos requisitos mínimos de integração de várias funções e departamentos da empresa (BROWNE et al., 1988), além disto serviu como núcleo de inserção de novas funcionalidades/módulos para o desenvolvimento da gestão de empresas de manufatura, através da incorporação de novas funcionalidades, que por fim desembocou nos sistemas ERP (Enterprise Resources Planning). A abordagem de planejamento hierarquizada, top-down (de cima para baixo), atendeu bem as necessidades impostas pelo mercado e as filosofias de planejamento estratégico dominantes. O desenvolvimento dos sistemas MRP II, veio a suprir algumas lacunas existentes no MRP, como a análise e suporte a cálculos quanto a capacidade (LAURINDO \& MESQUITA, 2000). 
Ainda algumas contradições podem ser apontadas entre alguns pressupostos do MRP e do MRPII (WORTMANN \& WIJNGAARD, 1992 apud ARTIBA \& ELMAGHRABY, 1996) ${ }^{4}$ :

$\checkmark$ A suposição que o mercado pode ser previsto contradiz a suposição que a demanda pode ser gerida;

$\checkmark$ A suposição que o lead time é conhecido por antecipação contradiz a suposição que o lead time é controlado pelas prioridades;

$\checkmark$ A suposição que o MRP I é uma ferramenta de suporte a decisão contradiz a suposição que seus planos serão executados;

$\checkmark$ A suposição que a gestão de materiais e do MPS contradiz a suposição que o MRP é neutro quanto a estrutura organizacional.

Dentre estas, destaca-se no escopo deste trabalho a suposição de que os lead time's podem ser conhecidos a priori. O que confronta a realidade de chão-defábrica, abrindo espaço à integração com os sistemas de capacidade finita e sistemas de controle de chão-de-fábrica (SFC) (BAUER et al., 1991).

Uma característica básica dos sistemas MRP, é a de funcionar através de ciclos, ou seja, se houver alguma inconsistência em um nível inferior, tenta-se voltar ao nível mais agregado de forma a acertar estas inconsistências, como por exemplo prazos não factíveis devido a excesso de capacidade, isto se repete quanto a novas "rodadas" do MRP, quando o sistema deve ter sido alimentado com dados sobre os

${ }^{4}$ WORTMANN, J.C.; WIJNGAARD, J. (1992). Beyond MRP. Production Planning and Control, v.3(3), p.225-226 apud ARTIBA, A.; ELMAGHRABY, S.E org. (1996). The planning and scheduling of production systems: methodologies and applications /Editorial, London, Chapman \& Hall. 
processamentos das ordens de forma a ter um correto status das ordens e dos estoques, de forma a possibilitar o planejamento viável.

Isto posto, vários argumentam que a falta de acurácia dos dados é um dos pontos fracos do sistema MRP. Tanto a imprecisão de dados estáticos (Estruturas de Produtos, Roteiros Produtivos, Tamanhos de Lotes de Produção), quanto de dados dinâmicos (status de ordens, status de equipamentos, posição de estoques, lead-times de produção) (CORREA et al., 1997; VOLLMANN et al., 1997), têm um forte impacto negativo no desempenho destes sistemas. BONNEY ${ }^{5}$ et al. (1993 apud BONNEY, 2000) demonstraram o forte impacto negativo que a falta de acurácia de estoques tem no desempenho de sistemas MRP, através de simulações através da teoria de sistemas de controle.

A constatação é de que os sistemas MRP são razoavelmente distantes da realidade de chão-de-fábrica, normalmente o horizonte usual de agregação de planejamento é de uma semana (chamado em inglês de time bucket) e apesar das funcionalidades do MRPII quanto a capacidade, é basicamente um sistema de capacidade infinita. Também é um sistema que assume uma posição estática quanto a dinâmica do chão-de-fábrica, assumindo lead time's fixos no tempo e pouco servindo de apoio a eventos inesperados, como quebra de máquinas, falta de transporte, falta de material, tempo de processo excessivo ou inferior, mudança de prioridade de ordem, etc... Eventos estes típicos e naturais no ambiente operacional da manufatura (HOWELLS, 2001).

${ }^{5}$ BONNEY, M.; POPPLEWELL, K.; MATOUG, M. (1994). Effect of errors and delays in inventory reporting on production systems performance. International Journal of Production Economics, 35, pp.345-353, 1993. 
A lógica de processamento dos sistemas MRP (VOLLMANN et al., 1997), procura isolar as rodadas MRP das perturbações de curto prazo através do chamado horizonte de fixação de ordens time-fence, que consiste em um período de tempo em que as ordens de produção planejadas ou em curso, permanecem "congeladas", ou seja, já não se possibilita alterações em suas propostas de fornecimento, o mesmo acontecendo quanto as ordens de produção abertas e em processamento. Isto visa a evitar um grande número de mensagens de exceção no sistema e reconhece que a lógica MRP não é adequada ao planejamento de curto prazo.

Estes deficiências levaram a integração de sistemas MRP, com sistemas de planejamento e controle de chão-de-fábrica como o Kanban, que constitui um sistema simples de controle e programação da produção da filosofia Just-in-Time. Note-se que a relação entre o planejamento baseado MRP e o planejamento Justin-Time, que inicialmente (cerca de 20 anos atrás) foram visto como formas de planejamento antagônicas e incompatíveis, acabaram por ser utilizadas concomitantemente na manufatura por muitas empresas (CORREA et al., 1997; SLACK et al., 1999), isto se deve justamente ao reconhecimento que o MRP encontra sua falha principal na gestão de chão-de-fábrica, aliado ao fato que as práticas JIT são fortemente direcionadas à melhoria do chão-de-fábrica, reconhecendo também o forte impacto na manufatura da dimensão social dos sistemas de produção, investindo em treinamento, operadores multi-qualificados de forma a atingir uma atitude das pessoas envolvidas com os sistemas produtivos de resolução de problemas descentralizadamente e que reforçando o papel do elemento humano em todos os níveis (SUZAKI, 1993).

A inabilidade dos sistemas MRP em lidar com as necessidades de planejamento, programação (e reprogramação) e controle de produção no curto 
prazo, dão ensejo também a utilização dos sistemas de planejamento de capacidade finita (FCS - Finite Capacity Scheduling), de forma a tratar a lacuna entre os sistemas MRP e o chão-de-fábrica (PORTER et al., 1999).

Quanto às técnicas de planejamento e controle da filosofia JIT, foram particularmente úteis na manufatura discreta de produtos de estrutura simples e de demanda relativamente estável, as técnicas de nivelamento, modelos mesclados, o Kanban e o foco na melhora do fluxo, são importantes ferramentas de melhoria de desempenho das operações, contudo, apesar de sua aplicação ter se ampliado a manufaturas do tipo job shop, principalmente de suas ferramentas visuais de programação e reposição, são ferramentas que apresentam grandes ganhos iniciais quando de sua aplicação em ambientes desestruturados (HOPP \& SPEARMAN, 2001), contudo sua permanência como diferencial competitivo e os ganhos de estoques inicialmente grandes, podem ficar rapidamente estagnados.

De fato os autores que se debruçam sobre o processo de raciocino da Teoria das Restrições apontam importantes imperfeições das técnicas de programação típicas do JIT. SOUZA (1997) aponta como um dos grandes defeitos das técnicas de programação da filosofia JIT, a busca pela capacidade balanceada, pois tende a ser apenas uma busca por ótimos globais e não da busca por um verdadeiro balanceamento. A constatação é de que estatisticamente os processos estão sujeitos a variabilidades naturais que afetam o desempenho das operações interdependentes das tarefas de manufatura, assim as operações de uma fábrica estão sujeitas a flutuações estatísticas que impedem o perfeito balanceamento dos fluxos de produção. Então a convivência com estes "desbalanceamentos" é inexorável, assim o foco do planejamento e gestão da manufatura deve ser muito mais no gerenciamento destes desbalanceamentos, através da gestão de gargalos (o que tecnicamente a teoria das restrições denomina como Recursos com 
Restrição de Capacidade - RRC), que podem e devem ser monitorados e muitas vezes intencionalmente determinados, ao invés de focar numa busca inglória pelo balanceamento das linhas de produção ou dos fluxos em ambientes job shop. De fato, a lógica do planejamento Kanban quando aplicada a ambientes discretos, embuti a existência de estoques entre as células de manufatura, representados pelos contenedores, que assim representam buffers ("amortecedores") a amenizar as flutuações do ciclo de demanda e fornecimento entre grupos de operações, residindo seu maior mérito na facilidade e clareza do controle destes estoques, quando comparado a estrutura de gerenciamento de estoques confusa que imperava em algumas fábricas, do que na real otimização dos níveis de estoque e atendimento de necessidades.

A Teoria das Restrições se caracteriza pela sua lógica e precisão matemática, contudo sua aplicação completa a sistemas de manufatura cai nos mesmos dilemas gerais dos sistemas de Programação Finita, é preciso que as informações e dados existam e estejam disponíveis a uma velocidade tão rápida quanto for a necessidade da fábrica, o que significa muito pouco tempo, talvez minutos, no caso de ambientes complexos de manufatura discreta (LINDAU, 1997). Além disto as restrições de um sistema produtivo são intimamente ligadas ao mix produtivo (diferentes combinações de produtos sendo produzidos ou demandados), o que torna mais crítico ainda a existência de dados e informações do chão-defábrica. 


\section{O Planejamento e Controle de Chão-de-Fábrica}

O Controle consiste das tarefas de medição e correção de desempenho, de forma a assegurar que os objetivos possam ser atingidos. Um pressuposto essencial é que se faz controle com o objetivo tanto de implementar ações de correção, quanto de acompanhar o processo.

O Controle de Chão-de-fábrica possuí duas finalidades principais (CHIAVENATO, 1991):

$\checkmark$ Correção das falhas ou erros existentes: o controle serve para detectar falhas ou erros - seja no planejamento ou na execução - para apontar as medidas corretivas para saná-las.

$\checkmark$ Prevenção de novas falhas ou erros: ao corrigir as falhas ou erros existentes, o controle aponta os meios para evitá-los no futuro.

CHIAVENATO (1991) desdobra os padrões de controle, em quatro tipos a seguir: Padrões de Qualidade; Padrões de Quantidade; Padrões de Tempo e Padrões de Custo. Encontramos ainda o desdobramento em quatro fases do processo de Controle: Estabelecimento de Padrões; Avaliação de Desempenho; Comparação do Desempenho com o Padrão; Ação Corretiva.

No âmbito do planejamento e controle de produção, se encontram os sistemas de Controle de Chão-de-Fábrica (Shop Floor Control - SFC) também conhecidos como PAC (do inglês Production Activity Control), nome dado aos sistemas de chão-de-fábrica no projeto COSIMA (COntrol Systems for Integrated MAnufacturing) do ESPRIT (European Strategic Program for Research and Development in Information Technology). 
A ISA (Instrument Society of America, 2000) na publicação Enterprise Control System Integration (Norma em construção) define as atividades que são próprias de um sistema de controle de chão-de-fábrica, algumas das principais são:

$\checkmark$ Alocação e Controle de Recursos: recursos incluem máquinas, ferramentas, mão-de-obra, materiais, outros equipamentos, documentos necessários a execução de uma operação e outras entidades que sejam necessárias ao início apropriado de uma operação. Além disto deve ser responsável por reportar o status e históricos destes estes recursos.

$\checkmark$ Liberação da produção: consiste na gestão do fluxo de informações na forma de ordens de produção, lotes e ordens de serviço pela liberação destas para equipamentos e times de produção específicos. A liberação de produção deve ser feita na necessidade que as ordens devem ser feitas e pode mudar em tempo real conforme os eventos do chão-de-fábrica ocorrem.

$\checkmark$ Coleta e Aquisição de dados: funcionalidade de obtenção dos dados de produção e paramétricos que estão associados aos equipamentos e processos produtivos. Inclui a responsabilidade de prover status de produção em tempo real e histórico destes dados.

$\checkmark$ Análise de Desempenho: funcionalidade de prover relatórios em tempo real das operações de manufatura e em comparação com os dados históricos.

$\checkmark$ Programação Detalhada das Operações: funcionalidade de prover sequenciamento baseado em prioridades, atributos, características e regras de produção, associadas com equipamentos e características de produtos. Este sequenciamento é finito e reconhece alternativas, processamentos com sobreposições de operações e processamento paralelo. 


\subsection{Modelos Funcionais para Sistemas de Chão-de-Fábrica}

A grande maioria dos modelos de planejamento de produção se baseia em um modelo hierárquico, dividido em três níveis de decisão: estratégico, tático e operacional. Tal estrutura é conhecida como Planejamento de Produção Hierárquico, que aborda os problemas de planejamento partindo de uma abordagem dos níveis agregados de tipos de produtos, daí para famílias e por para o nível de produtos (ARTIBA \& ELMAGHRABY,1996).

Uma visão de modelo de funcional para Controle de Chão-de-Fábrica (ShopFloor Control) é proposta por BAUER et al. (1991). Bauer e os outros autores propõem uma arquitetura híbrida, referenciada nas arquiteturas propostas pelo Bureau Nacional de Padrões dos Estados Unidos (NBS - National Bureau of Standars) e pela ISO (International Standards Organization).

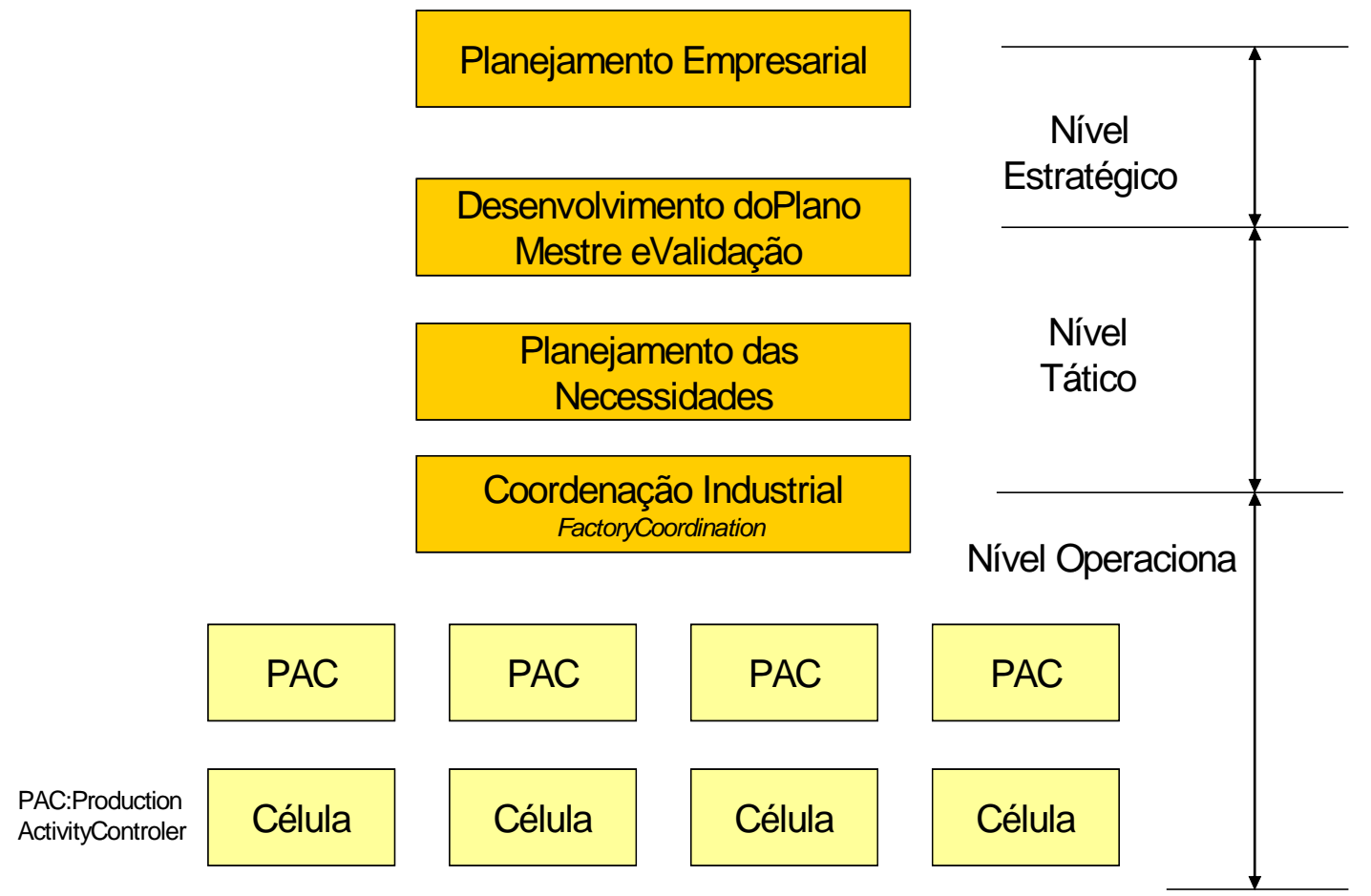

FIGURA 6 - Arquitetura de Planejamento e Controle de Produção 
Este modelo para controle de Chão-de-Fábrica é baseado no reconhecimento de dois principais subsistemas: Factory Coordination (FC) e Production Activity Control (PAC), localizados nos níveis inferiores de um modelo hierárquico de planejamento de Produção (apresentado na Figura 6). Este modelo assume a fábrica como uma série de células baseadas em produtos, sendo os fluxos de produtos dentro de cada célula geridos pelo sistema. Estas células não são independentes e normalmente semi-acabados fluem entre estas células, então esta gestão de mais alto nível é desempenhada pelo FC.

Bauer et al. (1991) propõem um modelo funcional do PAC (Production Activity Control), como sistema de Planejamento e Controle de Chão-de-fábrica, que é então detalhado nos seguintes blocos de funcionalidades (Figura 7):

\subsubsection{O Programador}

O Programador (Scheduler): a função do Programador é receber as ordens de produção de um sistema de planejamento de mais alto nível e assim desenvolver um plano detalhado que determina o uso preciso das diferentes instalações e recursos dentro de um prazo especificado. Uma boa programação depende de vários fatores como o design do chão-de-fábrica (projeto de instalações, layout, escolha de tecnologias, e outros fatores estruturais/tecnológicos), grau de complexidade das operações e da previsibilidade geral do processo de produção. 


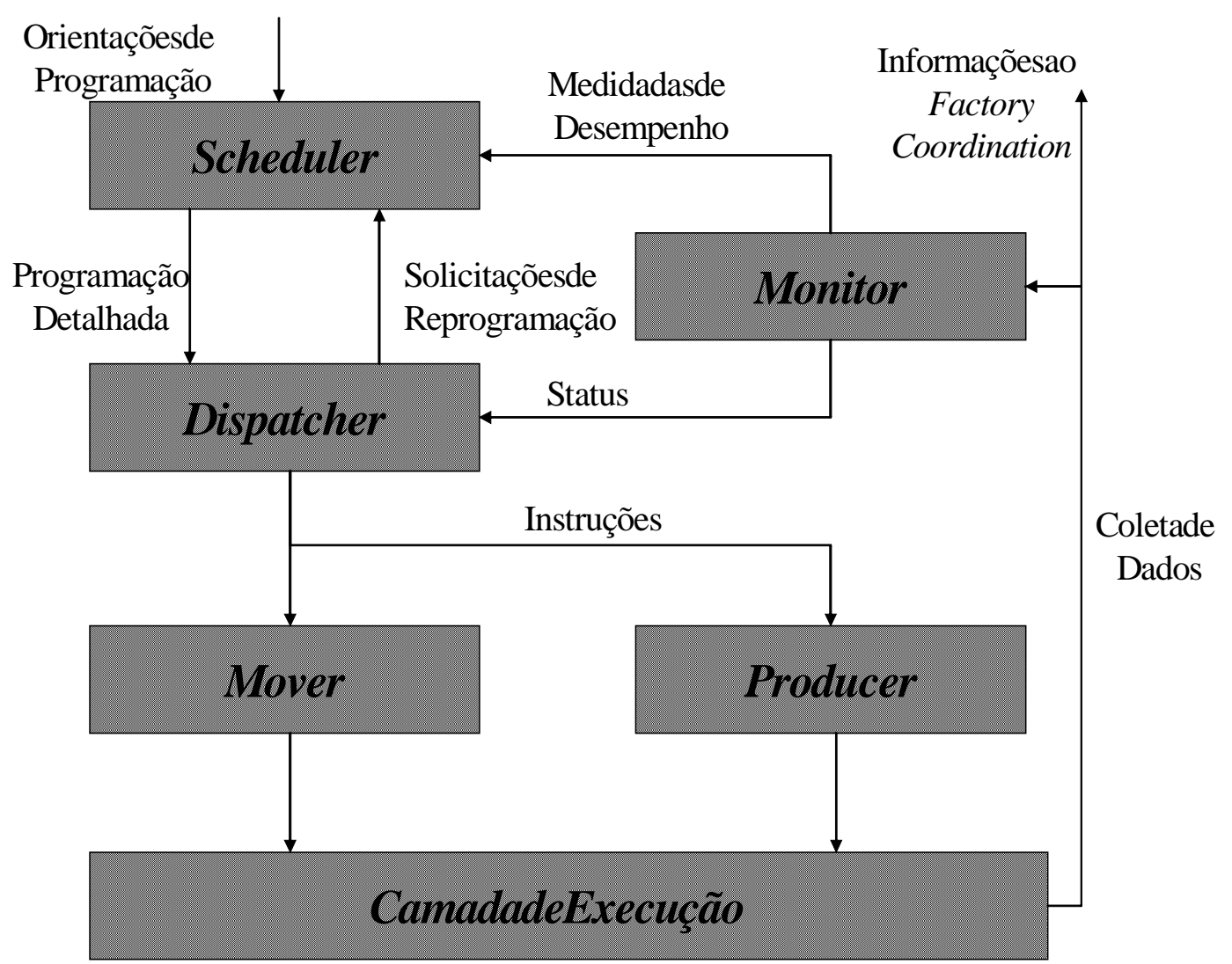

FIGURA 7 - Modelo Funcional de Controle de Chão-de-Fábrica

Adaptado de BAUER et al. (1991)

A programação é uma das funções do PAC, representa assim o aspecto do planejamento detalhado dentro de um sistema PAC. A programação é realizada levando-se em conta diferentes restrições e variáveis. Quando liberada para o chão-de-fábrica, torna-se suscetível às inconstâncias da realidade do ambiente de produção, em especial, frente aos eventos inesperados, como quebras de máquinas, faltas de material, absenteísmo, problemas de materiais, problemas de processos dentre os principais que podem surgir no chão-de-fábrica (CAETANO, 2000).

O Programador está contido em um modelo de gestão de chão-de-fábrica distribuído aonde a entrada do programador vem de uma sugestão de planejamento, advinda da camada mais agregada de planejamento, representada 
no modelo pela camada de funcionalidade Factory Coordinator. Esta camada proporciona a linha-mestra do planejamento do programador. A primeira atividade do programador é avaliar a viabilidade do plano proposto pela camada de FC. Sendo as propostas de planejamento da camada superior aceitas, a segunda atividade é programar as tarefas propostas pelo nível superior, utilizando aqui algoritmos, regras e simulações que proporcionem uma proposta de programação para as tarefas solicitadas. Por último, a tarefa do programador é liberar as ordens de trabalho para o programador.

Partindo então de um programa de produção, os eventos inesperados serão o real teste à flexibilidade e adaptabilidade de qualquer sistema e é papel do Emissor/Liberador lidar com este tipo de problema.

\subsubsection{O Emissor}

O Emissor/Liberador (Dispatcher) desempenha a função de lidar com eventos inesperados, acessando as decisões de chão-de-fábrica, tomando decisões de reprogramação, e quando necessário, solicitando novas programações por parte do Programador. Para funcionar corretamente, o Emissor/Liberador requer informações importantes, como:

$\checkmark$ A programação detalhada das diferentes operações a serem executadas;

$\checkmark$ Os dados industriais estáticos que descrevem como as tarefas serão executadas;

$\checkmark$ As informações sobre o corrente status do chão-de-fábrica.

Assim ter acesso as mais recentes informações de chão-de-fábrica é essencial de forma que o Emissor/Liberador possa tomar a decisão adequada na hora de informar uma nova ordem. Na realidade, um dos maiores obstáculos para o 
efetivo controle de chão-de-fábrica é a falta de dados precisos e atualizados. $\mathrm{O}$ Emissor/Liberador pode usar diferentes algoritmos e procedimentos para assegurar que os prazos sejam seguidos do modo mais efetivo. Quando uma decisão é tomada sobre o próximo passo a ser dado no processo de produção, o Emissor/Liberador envia instruções ao Transportador e ao Produtor para que estes possam levar a cabo os passos seguintes no processo de produção.

\subsubsection{O Monitor}

O papel do Monitor dentro dos diferentes níveis da manufatura, do planejamento estratégico até o PAC, é de fornecer informações para que as decisões sejam tomadas eficientemente entre as fases, para isto faz-se necessário informação consistente, precisa e no momento adequado. Dentro do PAC, a função do monitor é levar a informação necessária para o Programador e o Emissor/Liberador, facilitando que eles possam levar a cabo as suas respectivas tarefas de planejar e controlar. Assim a função do Monitor é dar sentido ao grande volume de dados que fluem do chão-de-fábrica, organizando-os em uma forma concisa, pertinente e compreensível para o Programador e o Emissor/Liberador. Desta forma o monitor funciona como um tradutor de dados em informação, com a finalidade de prover apoio para a sensata tomada de decisão na hora de programar e despachar funções. Podemos dizer que o Monitor no modelo de Bauer et al. (1991) desempenha três funções básicas: de Coleta de Dados em tempo real; de Análise de Dados transformando-os em informações úteis e de Suporte a Decisão, embutindo em si regras básicas para detecção de tendências e comportamentos fora dos parâmetros esperados. 


\subsubsection{O Transportador}

O Transportador (Mover) constituí o módulo responsável pelo direcionamento e liberação das informações de transporte da logística interno dentro do PAC, representando as funções de controle e mobilização de equipamentos de movimentação. Cujas restrições e status devem ser considerados e estar disponíveis para que os building blocks onde são feitas as tomadas de decisão dentro do modelo do PAC (representados pelo Programador e pelo Emissor/Liberador) executem suas funções.

\subsubsection{O Produtor}

O Produtor desempenha o papel de unidade de controle de processo dentro do PAC, tendo acesso a todas as informações exigidas para executar as várias operações na estação de trabalho. O Produtor pode ser tanto uma função automatizada quanto manual. A ordem principal para o produtor vem na forma de instruções específicas do Emissor/Liberador, e estas informações definem qual lote deve ser processado. O Produtor tem acesso às informações de processo dos itens e também dos dados de configuração dos lotes. O produtor traduz os dados para os específicos dispositivos e informa o monitor quando determinadas fases de produção são completadas.

\subsection{Processo de Liberação de Ordens}

TATSIOPOULOS (1997), propõem um modelo de sistema de controle de chão-de-fábrica, que aborda principalmente o que é por ele denominado como o processo elo entre os sistemas de planejamento e as operações de manufatura, o processo de liberação de ordens à produção. O processo de liberação de ordens (Orders Release) inclui às atividades que devem ser realizadas antes que uma ordem seja determinada para liberação por um sistema de planejamento para um 
sistema de execução. Estas atividades são necessárias para controlar o fluxo de informações e de ordens passando informações do sistema de planejamento para o sistema de execução de forma que se venha a garantir que as ordens liberadas tenham uma razoável probabilidade de serem executadas na data e quantidade desejadas.

Partindo desta definição, o processo de liberação de ordens (Orders Release) constitui na ligação chave entre o sistema de planejamento de produção e os sistemas de Controle de chão-de-fábrica. No trabalho de TATSIOPOULOS (1997) os termos sistema de planejamento e sistema de controle de chão-de-fábrica referenciam-se aos níveis do modelo de manufatura da ISO (empresa-fábricacélula-centro de trabalho-máquina/local de trabalho, em inglês enterprise-factorycell-workcenter-machine/workplace). Assim temos, que por exemplo, no nível coorporativo de uma empresa com diversas plantas produtivas, os sistemas de execução são considerados como caixas pretas pelo sistema de planejamento da empresa. Então no nível logo abaixo do nível coorporativo, ao nível do sistema de planejamento das plantas, os sistemas de execução são formados pelas linhas de produção/células, e assim por diante até o nível individual de local de trabalho.

Em termos de pacotes de software para gestão da produção, o processo de Liberação de Ordens desempenha um papel fundamental na definição do ciclo total de manufatura de uma ordem, tanto do ponto de vista funcional quanto do ponto de vista de dados.

Então segundo TATSIOPOULOS (1997), não existe ainda uma arquitetura comum do processo de liberação de ordens que permita diferentes fornecedores de soluções de sistemas desenvolverem padrões que permitam a cooperação entre suas soluções de maneira efetiva. Cite-se o esforço do projeto CIMOSA em produzir uma linguagem descritiva das soluções de Tecnologia da Informação, que 
contudo não atingiu grande penetração entre os fornecedores de sistema. Contudo este projeto não produziu uma arquitetura genérica de soluções ou de componentes de software e não havia ainda nenhuma teoria integrada que propusesse um modelo que apontasse quais objetos, estrutura de dados e processos são necessários em um módulo de aplicativo de controle e programação de chão-defábrica. Exemplo de modelo genérico proposto, dentre outros, o modelo COSIMA, concentrou-se em partes do problema, como a visão funcional de problemas temporais no chão-de-fábrica.

A arquitetura do COSIMA é baseada em três building blocks, o Scheduler, o Dispatcher e o Monitor, que se repetem nos níveis de controle de célula de manufatura e no nível de coordenação de plantas seguindo o modelo proposto por BAUER et al. (1991). Contudo na arquitetura proposta por TATSIOPOULOS (1997) há uma significante extensão do papel do Dispatcher (Emissor/Liberador de Ordens), desempenhando este um papel bem mais abrangente. A definição do projeto COSIMA de um Dispatcher é a de Programador em tempo real, o que se mostra mais apropriado para os níveis de decisão mais próximos do chão-defábrica (controle de células e de centro de trabalho). Nos níveis de decisão mais distantes do operacional (coordenação de fábrica e gestão da logística coorporativa), o Dispatcher deve assumir um papel mais abrangente incluindo todas as ações dentro da hierarquia de liberação de ordens. Isto é feito através da função básica de gestão de delegação em todos os níveis de decisão da hierarquia de gestão.

Esta Arquitetura foi construído utilizando a metodologia de Análise Orientada a Objetos (Object-Oriented Analysis - OOA) e é apresentada em três principais camadas: Camada de Conteúdo (estrutura modular); Camada de Objetos e Atributos (modelo de dados) e Camada de Serviço (funcional). 
A arquitetura propõe a definição de Modelos de Referência Genéricos, Parciais e Particulares, partindo do modelo genérico CIMOSA derivando em modelos parciais determinados pelas nove características de tipologia de sistemas produtivos (Tabela 2 ).

TABELA 2 - Tipologia de Sistemas de Produção e sua influência no processo de Liberação de Ordens (TATSIOPOULOS, 1997)

\begin{tabular}{|c|c|c|c|c|}
\hline Parâmetros & \multicolumn{4}{|c|}{ Valores dos Parâmetros } \\
\hline $\begin{array}{l}\text { 1. Grau de } \\
\text { Padronização } \\
\text { dos Produtos }\end{array}$ & $\begin{array}{l}1.1 \quad \text { Segundo } \\
\text { as } \\
\text { especificações } \\
\text { do cliente }\end{array}$ & $\begin{array}{lr}1.2 & \text { Catálogo } \\
\text { próprio } & \text { com } \\
\text { opções } & \text { não- } \\
\text { padrão } & \end{array}$ & $\begin{array}{l}1.3 \\
\text { Produtos } \\
\text { Standard } \\
\text { com } \\
\text { opcionais } \\
\end{array}$ & $\begin{array}{l}1.4 \text { Produtos } \\
\text { Standard sem } \\
\text { opcionais }\end{array}$ \\
\hline $\begin{array}{l}\text { 2. Estrutura } \\
\text { do Produto }\end{array}$ & 2.1 Explosiva & 2.2 Implosiva & $\begin{array}{l}2.3 \\
\text { Nivelada }\end{array}$ & $\begin{array}{l}2.4 \text { Indústria } \\
\text { de Processo }\end{array}$ \\
\hline $\begin{array}{l}\text { 3. Tipo do } \\
\text { Produto }\end{array}$ & $\begin{array}{l}3.1 \text { Bens de } \\
\text { Capital }\end{array}$ & $\begin{array}{ll}3.2 & \text { Bens } \\
\text { Industriais } & \end{array}$ & $\begin{array}{l}\text { 3.3 Bens de } \\
\text { Consumo } \\
\text { duráveis }\end{array}$ & $\begin{array}{l}3.4 \text { Bens de } \\
\text { Consumo } \\
\text { (Fast Moving } \\
\text { Consumer } \\
\text { Goods-FMCG) }\end{array}$ \\
\hline $\begin{array}{l}\text { 4. Gatilho de } \\
\text { Produção }\end{array}$ & $\begin{array}{l}4.1 \quad \text { Make-to- } \\
\text { Order (MTO) }\end{array}$ & $\begin{array}{l}\text { Make-to-Blanket } \\
\text { Order (MBO) }\end{array}$ & $\begin{array}{l}\text { Assembly- } \\
\text { to-Order } \\
\text { (ATO) }\end{array}$ & $\begin{array}{l}\text { Make-to-Stock } \\
\text { (MTS) }\end{array}$ \\
\hline $\begin{array}{l}\text { 5. Estrutura } \\
\text { de } \\
\text { Suprimentos }\end{array}$ & $\begin{array}{l}5.1 \text { Produção } \\
\text { Vertical }\end{array}$ & $\begin{array}{l}5.2 \text { Alto Grau de } \\
\text { "Subcontratação" }\end{array}$ & $\begin{array}{l}5.3 \\
\text { Montagem } \\
\text { Final } \\
\text { somente } \\
\end{array}$ & $\begin{array}{l}5.4 \quad \text { Empresa } \\
\text { Estendida }\end{array}$ \\
\hline $\begin{array}{l}\text { 6. Fluxo do } \\
\text { Processo } \\
\text { (Dimensão } \\
\text { Temporal) } \\
\end{array}$ & $\begin{array}{l}6.1 \text { Produção } \\
\text { "One-of-a-kind" } \\
(\mathrm{OKP})\end{array}$ & $\begin{array}{l}6.2 \text { Produção em } \\
\text { Lotes }\end{array}$ & $\begin{array}{l}6.3 \\
\text { Produção } \\
\text { Repetitiva }\end{array}$ & $\begin{array}{l}\text { 6.4 Produção } \\
\text { Contínua }\end{array}$ \\
\hline $\begin{array}{l}\text { 7. Layout do } \\
\text { Processo } \\
\text { (Dimensão } \\
\text { Espacial) }\end{array}$ & 7.1 "Job-shop" & $\begin{array}{l}7.2 \text { Operações } \\
\text { Seqüenciadas }\end{array}$ & $\begin{array}{l}7.3 \text { Célula } \\
\text { de } \\
\text { Manufatura }\end{array}$ & 7.4 Flow-Shop \\
\hline $\begin{array}{l}\text { 8. Estrutura } \\
\text { Logística }\end{array}$ & $\begin{array}{l}8.1 \quad \text { Uma } \\
\text { planta/sistema } \\
\text { de } \\
\text { almoxarifado }\end{array}$ & $\begin{array}{l}8.2 \\
\text { Multiplanta/Multi } \\
\text { almoxarifados }\end{array}$ & $\begin{array}{l}\text { 8.3 Sistema } \\
\text { de } \\
\text { Distribuição } \\
\text { /Produção } \\
\end{array}$ & $\begin{array}{l}8.4 \text { Sistema de } \\
\text { Distribuição/ } \\
\text { Armazenagem }\end{array}$ \\
\hline $\begin{array}{l}\text { 9. Tamanho } \\
\text { (Pessoal) }\end{array}$ & $\begin{array}{lr}9.1 & \text { Muito } \\
\text { Pequeno } \quad(<50 \\
\text { pessoas })\end{array}$ & $\begin{array}{l}9.2 \text { Médio porte } \\
(50<\text { pessoas } \\
<500)\end{array}$ & $\begin{array}{l}9.3 \text { Grande } \\
\text { porte } \\
(>500)\end{array}$ & $\begin{array}{l}9.4 \\
\text { Multinacional }\end{array}$ \\
\hline
\end{tabular}


Esta tipologia de sistema de manufatura baseada no modelo de SCHOMBURG, foi desenvolvida com base nas características da indústria mecânica e para uma planta isolada. Restrições apontadas que não invalidam as premissas propostas, cuja ampliação de escopo TATSIOPOULOS (1997) se propõem.

Neste modelo são discutidas as nove características desta tipologia empresarial, no processo de Liberação de Ordens e a influência da combinação de diferentes parâmetros. Segundo a discussão de um modelo de referência baseado na análise orienta a objetos, as combinações destes parâmetros necessitam uma instanciação do Modelo de Referência de Liberação de Objetos. Assim temos um modelo particular relativo às peculiaridades de uma empresa específica, que possuí assim diferenças de um modelo parcial de tipo de sistema produtivo ao qual a companhia pertence. Neste modelo faz se uso do conceito de herança, da análise orientada a objeto, para possibilitar a expansão do modelo geral, para sua instanciação em modelos particulares.

\subsubsection{Tipologia de Produção no processo de Liberação de Ordens}

Os seguintes subconjuntos de parâmetros têm importante influência no processo de Liberação de Ordens: Grau de Padronização dos Produtos (1); Estrutura do Produto (2); Fluxo do Processo (6) e o Layout do Processo (7).

Grau de Padronização dos Produtos (1): empresas que operam segundo um alto grau de "customização", ou seja que operam com os parâmetros 1.1 (especificações do cliente) precisam dar uma alta importância à documentação das ordens e às características próprias do processo produtivo, que devem ser levadas em conta no processo de liberação de ordens. Já para situação 1.2 (catálogo próprio com opções não-padrão) deve-se fazer uma diferenciação entre a parte do 
processo que é neutra (independente de estado) e genérica, daquela que é específica (dependente de estado), onde então o planejamento do processo produtivo deve ser interligado com o processo de liberação de ordens.

Influência da Estrutura do Produto: o parâmetro 2.1 (indústria explosiva), caracteriza um sistema produtivo onde grande importância do processo de Liberação de Ordens está na disponibilidade de material e nas características de perecibilidade do material. Em empresas do ramo eletrônico, esta característica é de igual ou maior importância que as considerações sobre disponibilidade de capacidade e programação, as quais tem sido objeto das principais pesquisas na área de sistemas de controle chão-de-fábrica.

Importância do Fluxo de Processo: sistemas de Produção do tipo 6.3 (produção repetitiva) tendem a ter um processo de Liberação de Ordens empurrado (por exemplo: Kanban), ao passo que aqueles do tipo 6.1 (produção "One-of-kind") e 6.2 (em lotes) utilizam tradicionais métodos de liberação de ordens empurrados. Os sistemas do tipo 6.4 (produção contínua) tradicionalmente não se utilizam do processo de Liberação de Ordens no nível de chão-de-fábrica.

Importância do Layout do Processo: valores de parâmetros 7.2 (operações seqüenciadas) e 7.3 (manufatura celular) têm necessidade de um processo de Liberação de Ordens que busque a meta de equilíbrio do fluxo ao invés do nivelamento da capacidade. Assim, a liberação de ordens deve buscar o balanço do fluxo dos centros de trabalho subseqüentes, e não só buscar o controle de filas de centros de trabalho chave como no caso dos sistemas de manufatura do tipo 7.1 (job shop).

Camada de Conteúdo do modelo de referência de Liberação de Ordens 
A camada de conteúdo apresenta a arquitetura geral do modelo de referência utilizando os "building blocks", de uma maneira similar à estrutura modular dos sistemas comerciais de software. O mecanismo de liberação de Ordens do Liberador (Releaser) deve tratar nos níveis superiores os seguintes problemas:

$\checkmark$ Dimensionamento de Lotes

$\checkmark$ Documentação de Ordens e da seleção de Listas de Materiais (Bill of Materials) e de Planos de Processo.

$\checkmark$ Controle de Carga e Disponibilidade de Capacidade

$\checkmark$ Disponibilidade de Material e Perecibilidade

$\checkmark$ Coordenação do fluxo contínuo e das células de manufatura.

O processo de Liberação de Ordens pode ser dividido, ainda segundo TATSIOPOULOS (1997) em três classes de funcionalidades: Gestão de Ordens (tamanho de lote, documentação); Gestão de Material (disponibilidade de material, perecibilidade de material) e Gestão de Capacidade (disponibilidade de capacidade, controle de carga). Podemos então definir um modelo genérico de sistema Liberador de Ordens com três "building blocks" com características próprias de funcionalidades (Figura 8). 


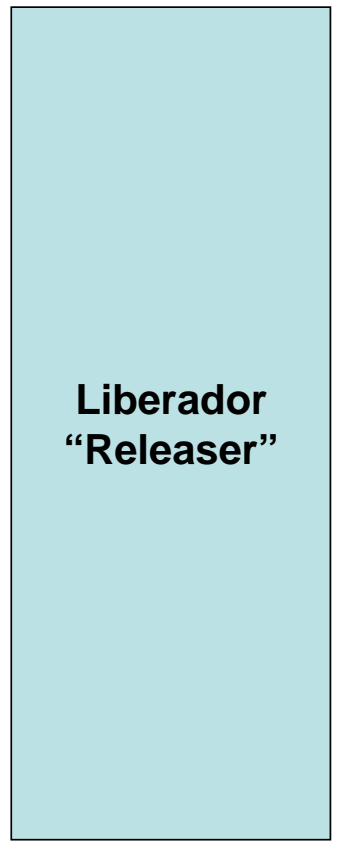

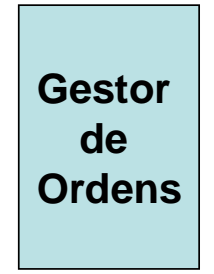
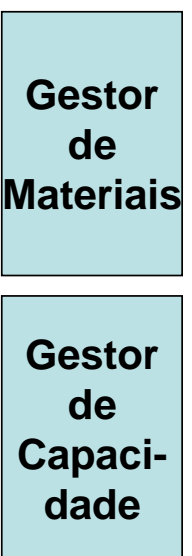

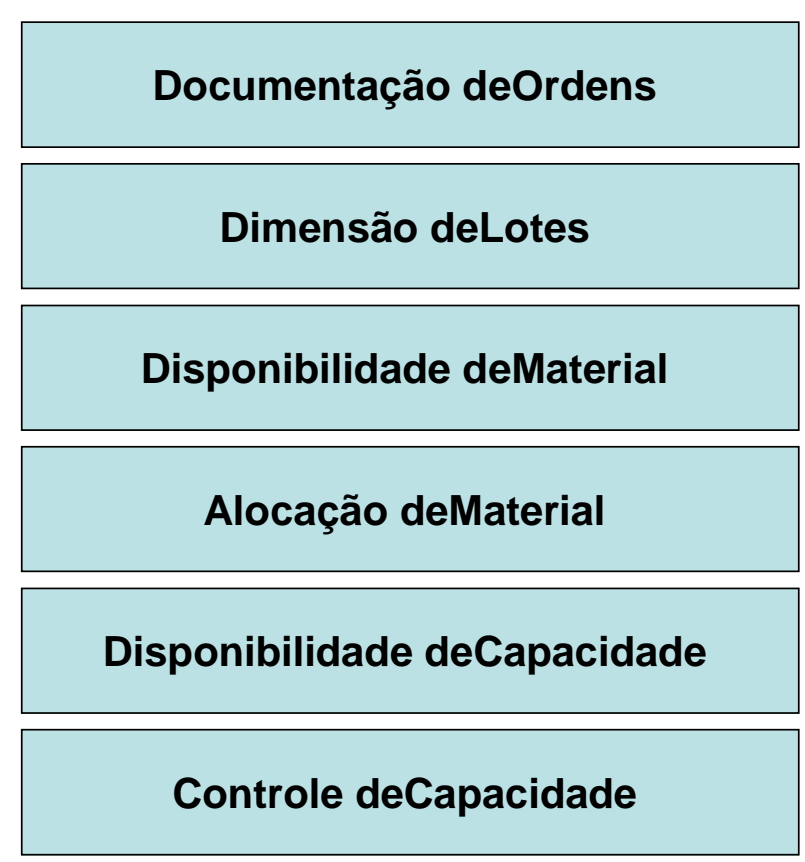

FIGURA 8 - Esquema Funcional de um Sistema de Liberação de Ordens Adaptado de TATSIOPOULOS (1997)

A Figura 9 descreve o relacionamento entre os níveis de decisão de planejamento e os tipos de ordens, onde à esquerda está representado o conjunto de ordens (vistas aqui como objetos do sistema de manufatura) utilizadas para a tomada de decisão da liberação de ordens e nas figuras à direita seu relacionamento com o modelo organizacional da ISO. Neste modelo a liberação de ordens pode ocorrer em cada nível organizacional e há uma correspondência de responsabilidade com o nível organizacional de tomada de decisão.

De acordo com o modelo, a empresa aceita Ordens de Venda e libera Ordens Planejadas de Produção (MRP) para as fábricas, que liberam Ordens de Trabalho (Work Orders) para as linhas/células, e estas liberam Lotes de Processamento (Process Batches) para os Centros de Trabalho. O relacionamento $M: N$ ( $M$ para $N$ ) entre tipos de ordens enfatiza as decisões de dimensionamento de lotes que existem em todos os níveis de liberação através do fluxo de controle de 
carga, ou seja, ordens podem ser agregadas por razões de setup ou desmembradas em função de lead-time.

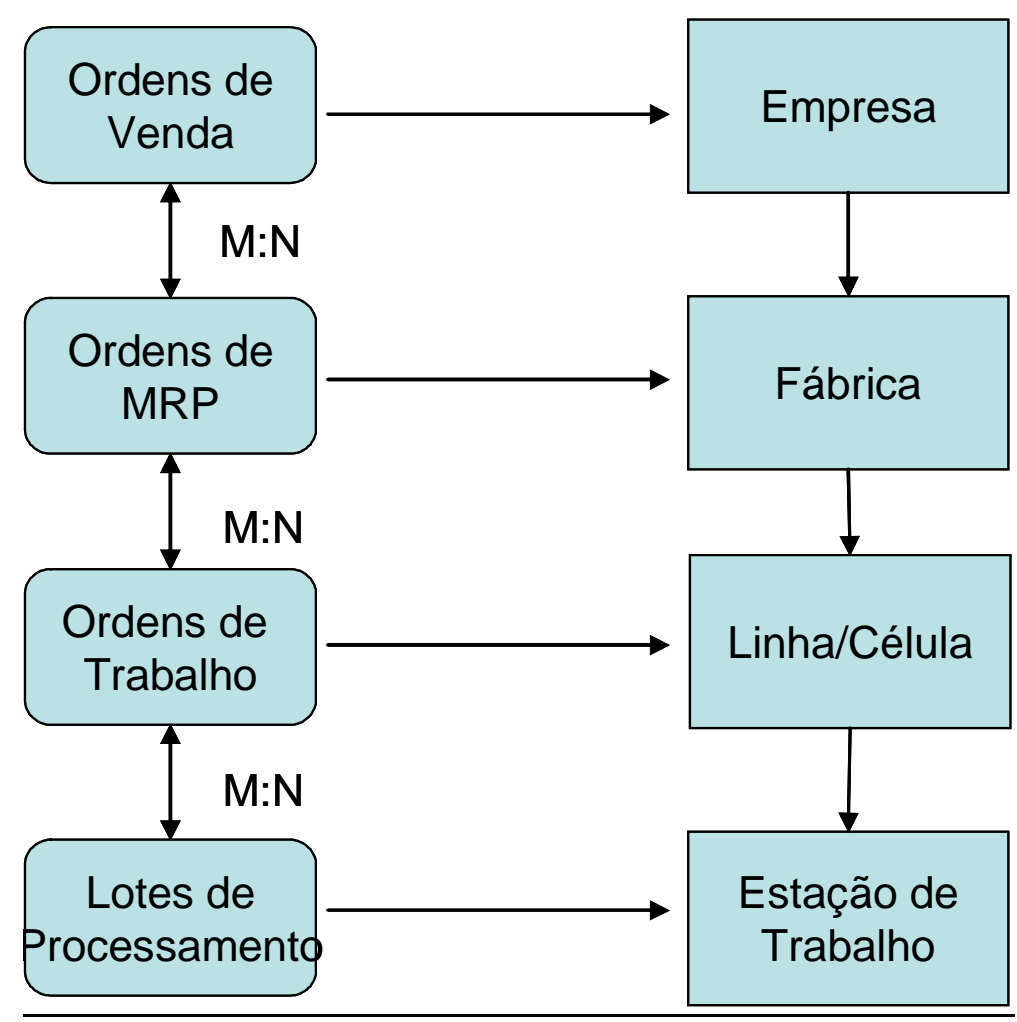

FIGURA 9 - Relacionamento dos Níveis Organizacionais e Tipos de Ordens

Adaptado de TATSIOPOULOS (1997)

\subsection{Estratégia de Modelagem de Dados para um Sistema de Manufatura Integrada}

ZHANG et al. (1996) apresentam uma estratégia de modelagem de dados de sistema de manufatura integrado, utilizada para modelagem de células de manufatura FMS (flexible manufacturing systems)(Figura 10), cuja abordagem baseada na modelagem orientada a objetos, desdobra em três as categorias de modelos que configuram um sistema de manufatura. 


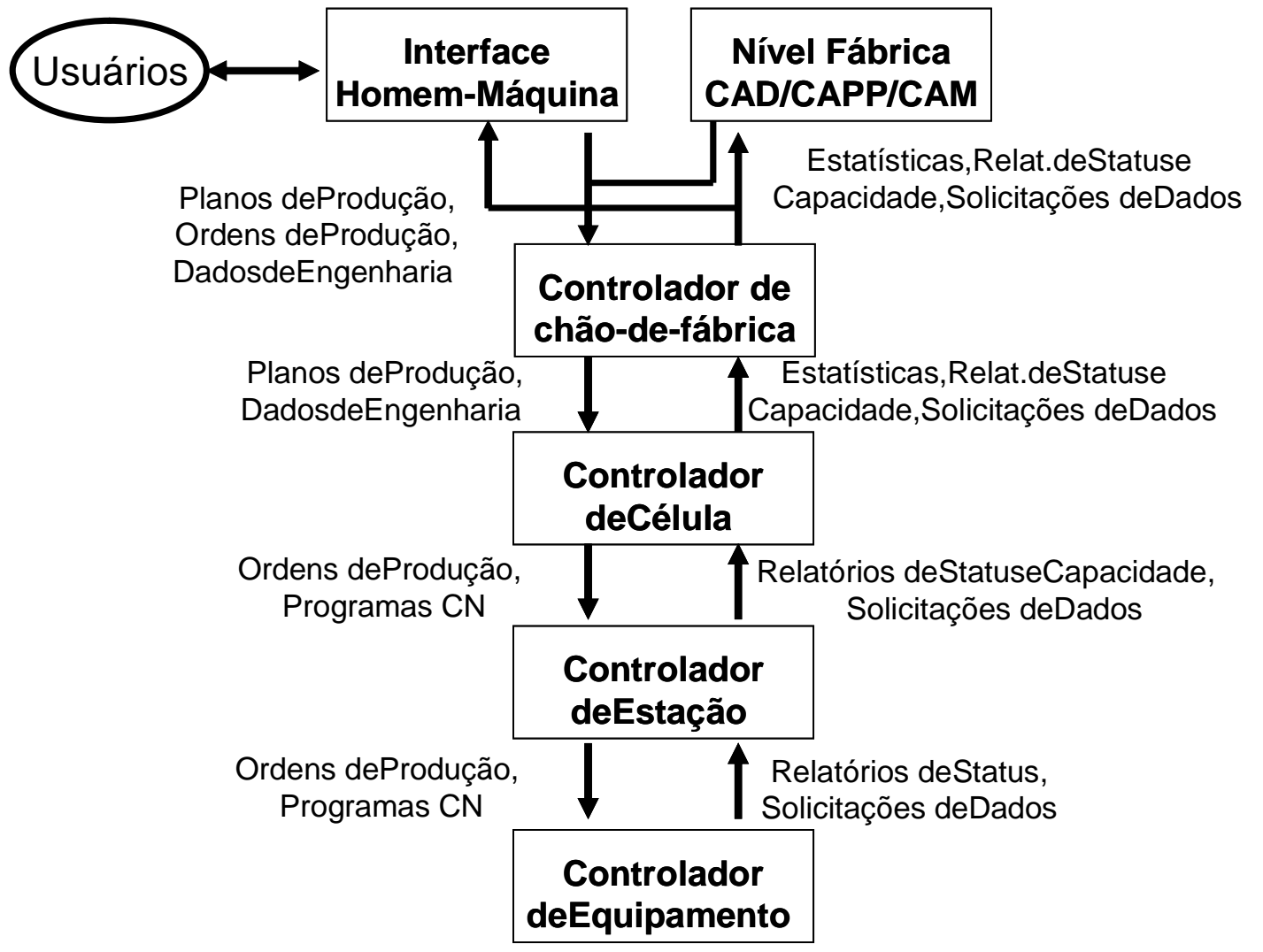

FIGURA 10 - Estrutura do Fluxo de Informação do Sistema de Controle de Manufatura proposto por ZHANG et al. (1996)

Modelo de configuração física de um sistema de manufatura: Para que um sistema de manufatura possa prover pessoas e aplicações de sistemas de manufatura com as informações necessárias, é preciso um modelo de dados que considere a configuração física do sistema. Este modelo pode ser organizado segundo as seguintes categorias de objetos de manufatura.

Categoria Equipamentos: são todos os objetos dos sistemas que operam segundo um controle numérico. É composto por máquinas-ferramenta, máquinas de medição em três coordenadas, AGV's (Automated Guided Vehicles), computadores.

Categoria de Recursos: são os objetos físicos do sistema que não são passíveis de programação ou de tarefas automatizadas. Classificam-se nesta categoria ferramentas, ferramental e dispositivos, pallets, material e pessoal. 
Informações como nome e parâmetros são importantes no planejamento de processo e para o processo de programação.

Categoria de Sistemas: consiste do reconhecimento de sistemas que constituem um sistema de manufatura, ou seja, o reconhecimento que em um sistema de manufatura existem subsistemas onde ocorrem fluxos de informação e onde decisões próprias a estes sistemas são tomadas. São exemplos os sistemas hierárquicos de informação de chão-de-fábrica, célula e estação de trabalho, ainda podemos citar sistemas de controle de almoxarifado (warehouse management) e controle de ferramentas.

Modelo Orientado ao Controle de Operações. Este modelo deve conter os objetos necessários para controle e programação das operações do sistema. São ordens de produção, planos de processo, planos de produção de células, operações, programas de controle numérico, programas de produção, lotes e requisitos de capacidade e material.

Modelo Orientado ao Monitoramento das Operações. Este modelo refere-se aos objetos que provêm o suporte as atividades de tomada de decisão dentro de um sistema de manufatura. Estes objetos são de três categorias: Relatórios Estáticos, são as estatísticas de desempenho da manufatura que proporcionam os níveis mais agregados de planejamento com as informações para a alocação de planos de produção; Relatórios de Capacidade, consistem dos relatórios de capacidade e capabilidade; Relatórios de Status, são as informações mais importantes, que visam garantir a confiabilidade do sistema e que reportam o status de equipamentos, estações de trabalho, células, itens e outros objetos de manufatura.

ZHANG et al. (1996), propõem que a abordagem de modelagem de um sistema de controle de chão-de-fábrica de uma célula altamente automatiza, uma 
FMS (flexible manufacturing systems) e uma célula composta de máquinas CNC (computerized numeric control - controle numérico computadorizado), típicas da manufatura discreta, integradas por um sistema DNC (distributed numeric control controle numérico distribuído), não diferem muito entre si. Do ponto de vista de integração da informação, a diferença principal é que em uma célula de manufatura DNC não haverá a necessidade de lidar com o fluxo de materiais dentro de um sistema de controle de chão-de-fábrica. Assim as técnicas utilizadas para modelagem de um sistema de chão-de-fábrica não diferirão entre si em seus princípios.

Após a conceituação dos objetos relacionados ao sistema de controle de chão-de-fábrica, ZHANG et al. (1996) propõem a utilização do conceito de Enterprise Activity (Atividades Empresarias), que consiste de um mecanismo de definição de uma unidade de atividade dentro do domínio empresarial para a modelagem de processo.

Os objetivos da modelagem da modelagem de dados ao nível de requerimentos devem ser:

$\checkmark$ definir os requerimentos de dados e informações de negócio utilizando um modelo estruturado orientado a objetos;

$\checkmark$ coletar informações suficientemente detalhadas para facilitar a construção de um modelo de informações consistente do sistema de informações.

Este mecanismo, esquematizado na Figura 11, serve como suporte a descrição das atividades empresarias, através de: 


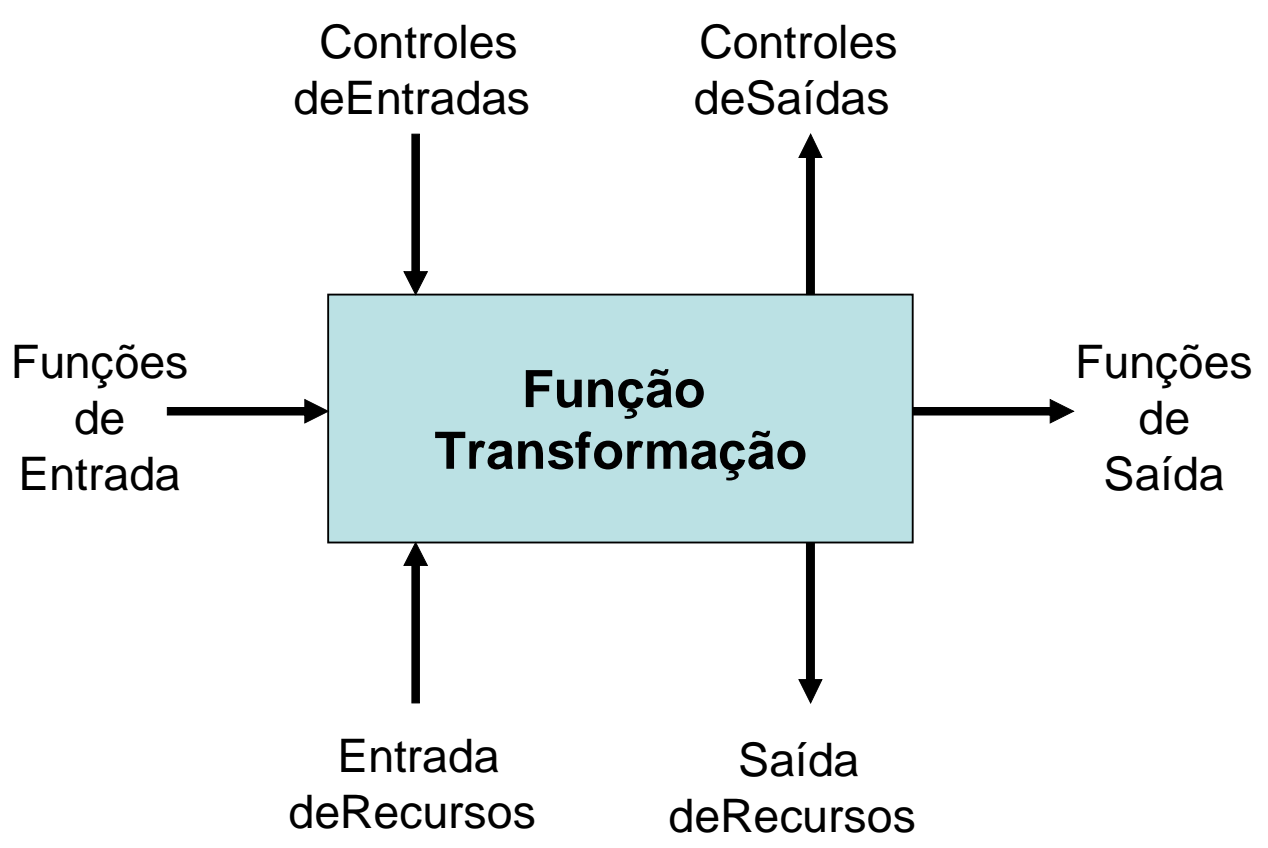

FIGURA 11 - Mecanismo de representação de atividade

Adaptado de ZHANG et al. (1996)

Funções de Entradas/Saídas: entradas são visões de objetos que são utilizados em funções empresariais. Saídas são também visões de objetos empresarias que são resultados de atividades empresarias.

Controles de Entradas/Saídas: são objetos ou elementos de informação que controlam ou restringem a execução das atividades de negócio. A saída de controle consiste em um conjunto de elementos de informação que definem o status de finalização de uma atividade empresarial.

Entradas/Saídas de Recursos: as entradas de recursos são objetos empresariais que são utilizados pelas atividades de negócio para executar suas funções. As saídas descrevem a volta destes objetos ao conjunto de recursos disponíveis para utilização. 


\subsection{Aplicações de Sistemas de Controle de Produção em Ambientes de Manufatura Discreta}

A complexidade dos sistemas de produção do tipo job shop constituem no mais complexo e desafiador ambiente para sistemas de programação de produção segundo McKAY \& BUZACOTT (2000). O desenvolvimento de sistemas genéricos de programação e controle de produção para este tipo de manufatura tem falhado em seus objetivos de desenvolver uma solução que seja modular e genérica o suficiente para seu aproveitamento em empresas diferentes (ANDERSSON, 1997). McKAY \& BUZACOTT (2000) apontam que as implementações de sistemas de programação e controle de produção neste ambiente continuam sendo bastante específicas a contexto peculiar das empresas onde se dão. Como resultado as soluções desenvolvidas pelas empresas são rígidas e exigem um quase completo desenvolvimento e configuração frente a mudanças que ocorram no sistema de manufatura.

McKAY \& BUZACOTT (2000) realizaram um estudo baseando em suas experiências com desenvolvimento de sistemas de programação em empresas de manufatura, em que realizaram dois experimentos de campo onde o auxílio de computadores foi considerado na melhoria do processo de programação de produção, sua conclusão é de que o uso de ferramentas de programação analíticas e algoritmos têm limitado uso na manufatura discreta, contudo, a utilização apropriada deste sistemas de Planejamento e Controle de Chão-de-fábrica pode ser de grande auxílio ao manejo do excesso de informações, como filtro de informações, e nas tarefas de programação de produção mais repetitivas, desta forma provendo melhorias ao processo de programação de produção.

O estudo foca no problema de programação de produção mais comum em ambientes de manufatura discreta, mas que contudo talvez seja o menos estudado 
pela teoria de sequenciamento de operações. Os autores tratam com o problema de programação em ambientes de manufatura discreta, caracterizado como job shop característico de muitas máquinas, muitos produtos e aonde ordens chegam como tarefas com quantidades, requerimentos e prazos determinados.

Contudo a utilização da definição de manufatura discreta, como classificação de sistema de manufatura é determinante para a construção de sistemas de planejamento e controle de produção e acaba por ser bastante imprecisa, pois as características de um sistema job shop podem ir desde o de uma empresa que produz os mesmos produtos de maneira intermitente para estoque (make-to-stock) até o de ambientes nervosos, produtores constantes de protótipos ou que enfrentam constantes mudanças de processo, materiais e especificações de produto e onde principal produto da empresa não é propriamente o bem manufaturado em si mas a venda de sua capacidade produtiva, como nas ferramentarias.

Então fica a questão de quais são os determinantes e problemas de um sistema de programação e controle de chão-de-fábrica em um ambiente job shop que produz intermitentemente produtos estáveis e maduros durante anos? Serão os mesmos de uma manufatura job shop focada na produção de protótipos ou que enfrenta continuas mudanças de materiais, processos e produtos?

Ainda segunda McKAY \& BUZACOTT (2000), as seguintes questões afloram sobre o estudo da aplicabilidade de ferramentas computacionais como auxílio às atividades do programador:

$\checkmark$ Sobre quais condições, as pessoas são a melhor escolha para realizar as atividades de controle de produção;

$\checkmark$ Em quais situações uma solução homem-computador é mais adequada; 
$\checkmark$ Se uma solução homem-computador é escolhida, quais atividades devem ser atribuídas ao computador e quais devem ser atribuídas ao homem.

O objeto de estudo compreendeu duas plantas de manufatura discreta, a primeira (planta A) de característica de alto volume de produção, com um mix de produção relativamente pequeno. A planta trabalhava com uma previsão de três meses, com detalhamento mensal da previsão de seus clientes. O programador tinha sob sua responsabilidade satisfazer a demanda do mês e gerar um planejamento detalhado da programação nas duas próximas semanas, além de ajustar a programação diária e alterar as seqüências conforme necessário.

A planta rodava um sistema MRP-II clássico, então a demanda podia ser obtida por item e com prazos determinados. Sob sua responsabilidade o programador tinha quatro linhas de produção e cerca de uma dúzia de itens. Diversos recursos produtivos podiam ser compartilhados e havia diversos fluxos possíveis de produção para a mesma peça.

O programador tinha então sob sua responsabilidade a decisão de o quê produzir, onde e quando, determinando os lotes de produção. A fábrica era bastante automatizada, envolvendo o estado da arte na produção de componentes eletrônicos. Sendo sua reputação como a de ser uma das melhores plantas do mundo em seu segmento, em termos de qualidade, eficiência e efetividade. A fábrica ainda se caracterizava por ser um ambiente em o parque fabril era bastante integrado e automatizado, por células de manufatura CIM.

O objetivo inicial do estudo era o de estudar o processo de programação de produção de forma a permitir que este fosse automatizado, de forma a garantir um desempenho produtivo ainda melhor. A demanda desta melhoria havia partido da direção da empresa, que acreditava que havia uma boa oportunidade de melhorias 
do desempenho operacional através da adoção de métodos quantitativos no processo de programação.

Foi identificado que a maior parte das atividades executadas pelo programador consistia da tomada de decisões mecânicas, como simples sequenciamento baseados na lógica JIT, características do maquinário e atributos de processo (setups, tempos de processamento, número de contenedores, etc..). Estes tipos de decisões são claramente passíveis de serem automatizados e sujeitas a modelos de decisão obtidos através de regras e heurísticas. Contudo uma porcentagem que variava de 10 a $15 \%$ por cento das decisões fugiam deste padrão e tinham que ser tratadas como exceções e só após um tratamento destas exceções se mostravam aptas a serem tratados por modelos pré-determinados. Estas exceções mostravam-se como relaxamento de restrições ou confirmações destas para a atribuição de métodos quantitativos, que afetam eventuais a utilização de regras e modelos de decisões automatizados que pudessem ser aplicados aos problemas de programação e controle.

De fato, o programador focava-se nas incertezas, riscos e mudanças do status da fábrica e dos planos. Sua atitude era de antecipação do futuro e de reação adequada a este modelo. Algumas de suas decisões eram sutis e certamente podiam até passar despercebido, como a de evitar programar lotes no terceiro turno, devido a falta de suporte da engenharia de processo. Outra característica de comportamento detectado foi a de alocar um lote de produção de um item que há um bom tempo não tinha sido produzido, no turno do dia entre a terça-feira e a quinta-feira (seu objetivo foi o de ter tempo suficiente para preparar o time durante a segunda-feira e permitir que o máximo de sua atenção estivesse disponível em ajudar e acompanhar o time de produção). 
A segunda planta (B), consistia de uma grande fábrica, com um volume relativamente baixo e grande variedade produtos. A programação era similar a planta A: o programador era informado de um detalhado plano de necessidades diárias para cerca de vinte semanas. O sistema legado, SAP, informa o programador com as informações tradicionais, número do item, data de necessidade e quantidades. A tarefa do programador era gerar um plano detalhado para os próximos dois dias, um plano aproximado para as duas próximas duas semanas e eventualmente para as oito semanas seguintes.

Esta planta era uma típica planta de processamento de aço, com equipamentos de tecnologia tradicional, algumas centenas de componentes a serem geridos e uma grande variedade de fluxos de processo possíveis. Os tamanhos de lote eram bastante variáveis, tendo o programador autonomia para a alteração do tamanho de lotes conforme necessário. O fornecimento de matéria prima constituía grande restrição à alteração das seqüências de planejamento, pois a característica do processo produtivo das siderúrgicas, que eram os principais fornecedores de matérias-primas exigia um bom tempo de antecipação para o fornecimento, a isto se somava a grande disparidade da qualidade do aço fornecido e a grande variabilidade de entrega quanto a quantidades e tempo dos fornecedores. A tarefa principal do programador era a de encaixar as ordens de produção entre as diversas possibilidades possíveis de processo de forma a sempre atender os prazos dados aos clientes, o que o sujeitava a um grande esforço e variabilidade no ambiente produtivo. 
TABELA 3 - Características das Plantas Industriais estudadas por McKAY \& BUZACOTT (2000)

\begin{tabular}{|l|l|l|}
\hline Características & Planta $\boldsymbol{A}$ & Planta $\boldsymbol{B}$ \\
\hline Foco no sequenciamento & Sim & Não \\
\hline Ambiente CIM & Alto & Baixo \\
\hline Experiência do Programador & Baixa & Alta \\
\hline Número de Recursos & Baixo & Alto \\
\hline Pressão sobre o Programador & Baixa & Alta \\
\hline Grau de Especialização da Fábrica & Alto & Baixo \\
\hline
\end{tabular}

A observação das atividades dos programadores mostrou que estes tinham em mente três atividades básicas:

$\checkmark$ Lidar com informação incompleta e ambígua. Consiste na tarefa de buscar as informações no chão-de-fábrica, utilizando-se da experiência e anotações dos eventos passados, tomar decisões com informações parciais, buscar informações e dicas que indiquem a futura ocorrência de um evento inesperado;

Lidar com exceções e relaxar restrições. Atitude de fazer escolhas como por a frente o lote que possui o menor número de opções de processo, procurar contornar as restrições de maneira adaptativa (por exemplo negociando prazos e quantidades com vendas), negociar horas-extras, escolha seletiva de turnos (o programador sabe que determinada turma de operadores conhece melhor certo produto ou que um grupo de operadores é mais habilidoso e experiente); 
Lidar com variações entre os dados de processo e produto e a realidade. Os programadores procuravam e conheciam os problemas com planos de processo e listas de matérias. Ainda sabiam quando as estimativas de tempo de processo podiam estar sub ou super estimadas e lidavam com estas variações para atingir os objetivos.

Então McKAY \& BUZACOTT (2000) propõem que o processo de trabalho dos programadores segue os seguintes sete passos:

$\checkmark$ Avaliação do corrente status do chão-de-fábrica;

$\checkmark$ Identificação das ordens e processos que estão com problema;

$\checkmark$ Imediato resequenciamento e realocação de ordens e recursos para lidar com os problemas detectados;

$\checkmark$ Atualização do cenário da produção após o passo anterior.;

$\checkmark$ Identificação de problemas futuros;

$\checkmark$ Atuação nas restrições que implicam nos possíveis futuros problemas detectados;

$\checkmark$ Programação das ordens sem perspectivas de serem problemáticas em função, primeiro a atender os passos anteriores contudo seguindo as prioridades usuais (datas de necessidade, preferência por seqüências de produção ideais, etc...).

A conclusão geral é que muitas vezes as soluções informatizadas não são capazes de suportar ou substituir a complexidade das tarefas do programador, e em outros casos, não há justificativa para a utilização de soluções complexas de automatização da função de programação. 
O estudo resulta em um diagnóstico dos problemas de programação onde, no caso da planta $B$, foi adotado um sistema que suportasse a parte mecânica de programação, deixando as incertezas a cargo do programador e no caso da planta A, concluiu-se que como predominavam problemas de programação de solução mecânicos, não sendo justificável a adoção de uma solução automatizada.

McKAY \& BUZACOTT (2000) propõem que em ambientes job shop, seja feita uma análise (Figura 12) do composto Volume de Produção versus Carteira de produtos, para avaliação da necessidade de implantação de um sistema de programação e controle de produção automatizado em ambientes job shop.

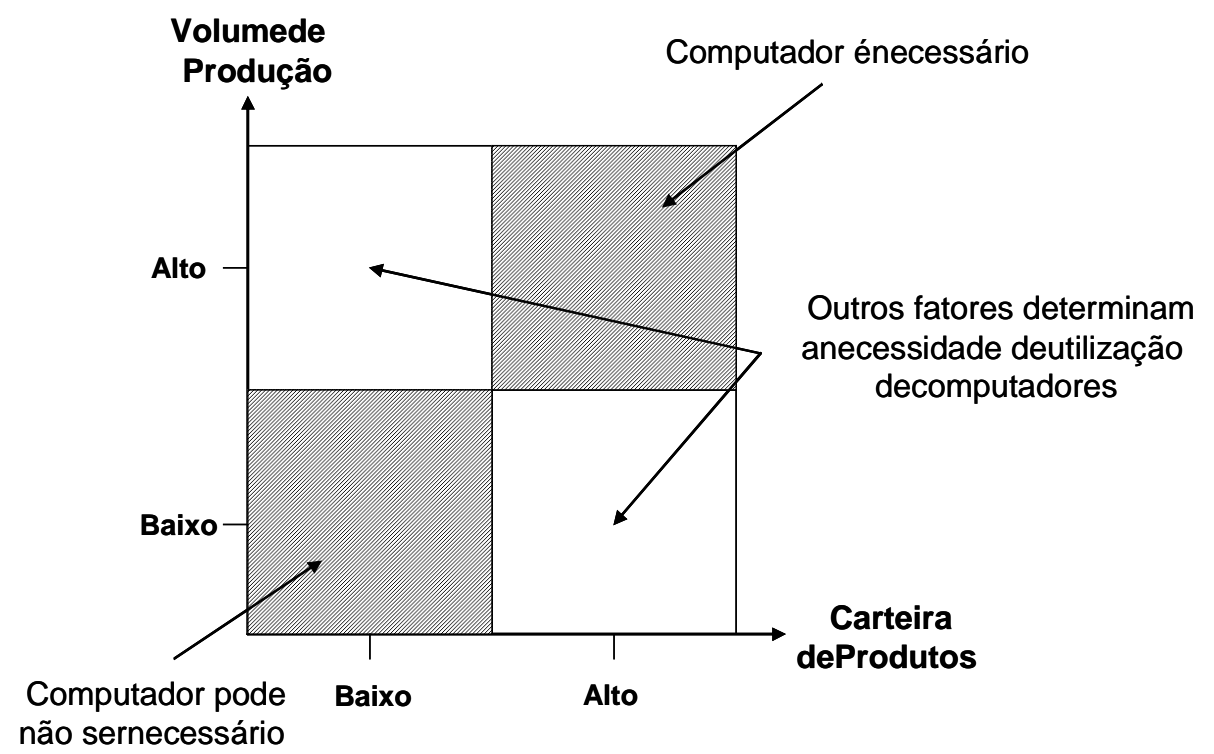

FIGURA 12 - Características para avaliação de uso de Sistemas de Programação Automatizados 


\subsection{Coleta de Dados Automática e seus Impactos na Produtividade}

LINDAU (1997) aponta as melhorias de desempenho alcançadas pela utilização de sistemas de coleta de dados automáticos. Este estudo mostrou um impacto positivo na utilização de mão-de-obra, mas apontou também que a utilização destes sistemas apresentou melhorias também nas taxas de utilização de máquinas, de equipamentos de transporte e na diminuição dos níveis de inventário.

TABELA 4 - Sistemas de Coleta Automática de Dados estudados por LINDAU (1997)

\begin{tabular}{|c|c|c|c|}
\hline Produtos & $\begin{array}{l}\text { Processo de } \\
\text { Manufatura }\end{array}$ & $\begin{array}{l}\text { Método de } \\
\text { Coleta de } \\
\text { Dados }\end{array}$ & Benefícios Apontados \\
\hline Computadores & Montagem & $\begin{array}{l}\text { Código de } \\
\text { Barras }\end{array}$ & $\begin{array}{l}\text { Melhor visualização das ordens } \\
\text { de produção; redução de } 20 \% \text { no } \\
\text { lead-time. }\end{array}$ \\
\hline $\begin{array}{l}\text { Componentes } \\
\text { Plásticos }\end{array}$ & $\begin{array}{l}\text { Processo } \\
\text { Produtivo } \\
\text { Completo }\end{array}$ & $\begin{array}{l}\text { Código } \\
\text { Barras }\end{array}$ & $\begin{array}{l}\text { Menor número de "rodadas" MRP } \\
\text { visibilidade das ordens de } \\
\text { produção; menor número de } \\
\text { pessoas envolvidas na coleta de } \\
\text { dados. }\end{array}$ \\
\hline Moto-Serras & Montagem Final & $\begin{array}{l}\text { Código } \\
\text { Barras }\end{array}$ & $\begin{array}{l}\text { Diminuição de estoques; melhor } \\
\text { atendimento dos prazos dos } \\
\text { clientes. }\end{array}$ \\
\hline Moto-Serras & Almoxarifado & $\begin{array}{l}\text { Código de } \\
\text { Barras }\end{array}$ & $\begin{array}{l}\text { Diminuição de estoques de } 30 \% \text {; } \\
\text { expedição mais ágil. }\end{array}$ \\
\hline Ferramentas & Expedição & Expedição & $\begin{array}{l}\text { Facilidade de expedição de } \\
\text { pedidos; agilização do processo } \\
\text { de faturamento. }\end{array}$ \\
\hline Armamentos & $\begin{array}{l}\text { Linha } \\
\text { Usinagem }\end{array}$ & radiofreqüência & Melhor rastreabilidade. \\
\hline $\begin{array}{ll}\text { Serviços } & \text { de } \\
\text { Usinagem } & \end{array}$ & Usinagem & $\begin{array}{l}\text { Código de } \\
\text { Barras e Leitura } \\
\text { de Cartões } \\
\text { Magnéticos }\end{array}$ & $\begin{array}{l}\text { Aumento de utilização de } \\
\text { equipamentos em 11\%; melhor } \\
\text { custeio }\end{array}$ \\
\hline
\end{tabular}

Este trabalho demonstra que as características de dados e informações de operações de manufatura diferem bastante em função do nível de planejamento em que serão utilizadas, se para o nível de planejamento de produção (nível em que tipicamente trabalha os sistemas MRP, de necessidades para semana ou dias médio/longo prazo) ou para o nível de programação de produção (seqüências de 
ordens, com determinação de minutos e considerações de carga máquina), contudo dois requisitos são comuns quaisquer que sejam as informações de manufatura necessárias: a necessidade de qualidade desta informação para um bom desempenho do controle de planejamento; e que estas informações sejam geradas e obtidas junto ao nível operacional.

Esta diferença de natureza das informações pode ser vista de outra maneira, as informações de planejamento são tipicamente informações para atualização e mudança de planos de médio e longo prazo, como informações sobre tempos de operação, freqüências de eventos, grau de utilização de recursos, registros de eventos, volumes de produção e históricos de ordens. O objetivo principal deste tipo de informação é detectar desvios nos planos de médio e longo prazo.

As informações de programação podem ser vistas como informações de controle de produção, ou melhor, informações utilizadas para uma reprogramação eficiente. Este tipo de informação deve conter o status atual dos recursos (máquinas, homens, materiais, informações, dentre os principais), possibilitando assim a determinação de prioridades de ordens de produção.

Para LINDAU (1997), na coleta de dados tradicional, tanto de planejamento quanto de programação, pessoas estão envolvidas no processo em um certo grau, portanto estes dados estão sujeitos a um relativamente alto grau de erros até que estes dados cheguem ao sistema (CAETANO, 2000). Porém é baseado nestes dados que se pode fazer um feed-back entre o nível operacional e tático, podendo se fazer a alocação, sequenciamento e programação de recursos, assim a abrangência, acurácia e prontidão destas informações é fundamental na otimização destes recursos. 
LINDAU (1997) conclui então que os sistemas de coleta automática de dados não têm sido utilizados de forma a constituir uma fonte realística de aumento de produtividade. A maneira mais comum de utilização destes sistemas têm sido a de coletar dados de planejamento, formando um simples depósito de dados, ou seja, registrando dados a respeito de apontamento de horas de trabalho, utilização de máquinas, registro de inventários, volumes de produção e rastreabilidade de lotes, dados estes cuja perspectiva de utilização reside muito mais na análise de médio e longo prazo.

A coleta de dados automatizada tem por si só um efeito de aumentar a produtividade, pois a coleta destes dados torna-se mais fácil, causando um menor esforço de mão-de-obra neste processo. Porém o grande salto de produtividade pode ser conseguido com o que LINDAU (1991) chama de 'a ligação perdida', ou seja, a coleta de dados com foco nos dados de programação, portanto não só uma coleta de dados focada no registro de informações para mudança de planos e médios prazos, cuja natureza é essencialmente de registro, mas uma aquisição de informações feita de maneira direcionada a pontos específicos e com tempos de atualização muito mais rápidos, de maneira a suportar o controle e programação de produção, por meio de uma abordagem que possibilite uma tomada de ação proativa sobre os eventos inesperados do dinâmico chão-de-fábrica.

Exemplos de usos de recursos desnecessários devido a falta de integração de dados com o processo de programação, causando a propagação de eventos pelo ambiente fabril, constatados por este estudo foram: separação desnecessária de ferramentas; setup desnecessário; envio de kits de componentes desnecessário; setup de linha desnecessário; horas-extras não utilizadas por falta de material. LINDAU (1997) demonstra que mais de cinqüenta por cento dos eventos que interromperam a produção (quebra de equipamento, falta de material, atrasos de 
entrega, problemas de qualidade), afetaram o processamento das operações subseqüentes e geraram perdas produtivas, podendo ter sido evitadas estas perdas com a adequada utilização da informação sobre os eventos inesperados.

Portanto pode-se concluir que os dados coletados no chão-de-fábrica, podem ser basicamente classificados segundo a natureza de sua utilização como:

$\checkmark$ Dados de Planejamento: dados coletados com foco em manter rastreabilidade e registro de operações para posterior tratamento, onde sua utilização para controle de planejamento se dá na melhor hipótese para registrar entradas de estoque no final do dia, possibilitando atualização destas posições para as próximas rodadas de um módulo ou sistema de MRP.

$\checkmark$ Dados de Programação: são os dados coletados com o foco de dar suporte ao processo de programação, ou seja, monitorar quebra de máquinas, falta de materiais ou ferramentas, desvios de tempos processo que representem a dinâmica de curtíssimo prazo do processo de programação de produção, ou ainda, possibilitar uma fotografia instantânea da produção de forma a possibilitar a simular impactos de um resequenciamento devido aos eventos internos inesperados, como os acima citados, ou a mudança de prioridades devido a uma necessidade externa, como a entrada de um pedido de cliente urgente.

Então uma conclusão direta é que a aplicação de uma solução de sistema supervisório como a tratada neste trabalho, encontra sua utilização efetiva se voltada principalmente a coleta de dados de programação, para suporte ao processo de programação e interligado a sistemas de planejamento com capacidade finita. 


\subsection{Sistemas MES}

$\mathrm{Na}$ literatura e presente em soluções de software é comum a expressão sistemas MES (Manufacturing Execution Systems ou Sistemas de Execução de Manufatura). Esta definição é bastante abrangente e se refere a uma generalização de sistemas de suporte a manufatura.

MARKS \& SCORZA (1997) definem um MES com as seguintes características:

$\checkmark$ Um MES é uma aplicação de manufatura, não um MIS (Management Information System, ou Sistema de Informações Gerenciais)

$\checkmark$ Um sistema MES foca em execução e gerenciamento do processo produtivo

A Manufacturing Execution Systems Association (MESA), define as atividades que um sistema desempenha no chão de fábrica, a Figura 13 exibe as funcionalidades e como elas interagem com os outros sistemas e processos.

A seguir serão descritas as principais características das funcionalidades de um sistema MES segundo a MESA (MESA, 1997a; MESA, 1997b; MESA, 1997c).

\section{Alocação e recursos de materiais e ferramentas}

Gerenciamento de máquinas, ferramentas, habilidades, materiais, outros equipamentos, e outras entidades como documentos que devem estar disponíveis para que a operação possa ser iniciada. Propicia histórico detalhado dos recursos e garante que o equipamento está propriamente preparado. Além de status em tempo real. O gerenciamento destes recursos inclui reserva e envio para satisfazer os objetivos do calendário de produção. 


\section{Gerenciamento da qualidade}

Propicia análise em tempo real de medidas/parâmetros para assegurar controle de qualidade e para identificar problemas que requeiram atenção. $O$ sistema pode também recomendar ações corretivas, correlacionar ações e resultados determinando a causa. Podem incluir funções de rastreabilidade de dados de qualidade e produção e integração com sistemas de gerenciamento de sistemas de laboratório.

Um sistema MES mais sofisticado poderia comparar a qualidade do produto com dados históricos para ajudar a descobrir qual parte do processo causou o defeito. Este uso de dados do MES o direciona para análise exploratória de dados e análises de inferência estatística para determinar tendências ao longo do tempo.

\section{Planejamento das operações}

Propicia uma seqüência de operações baseada em prioridades, atributos, características, e/ou receitas associadas a uma produção específica para minimizar o setup. Trabalha com capacidade finita e reconhece operações alternativas e paralelas para calcular com exatidão tempo de processo e carregamento dos equipamentos para ajustá-los aos padrões.

\section{Gerenciamento do processo}

Monitora a produção e controla ou corrige automaticamente ou propicia um apoio à decisão para corrigir e melhorar as atividades durante o processo. Essas atividades podem ser intra-operacionais e focar especificamente em máquinas ou equipamentos sendo monitorados e controlados como também podem ser atividades interoperacionais que pode ser definida como tracking (rastreabilidade) do processo entre operações, gerenciamento de alarmes para assegurar que o pessoal está informado sobre mudanças de processo que estão fora das 
tolerâncias aceitáveis. Propicia também interfaces entre equipamentos inteligentes e MES através de coleta e aquisição de dados.

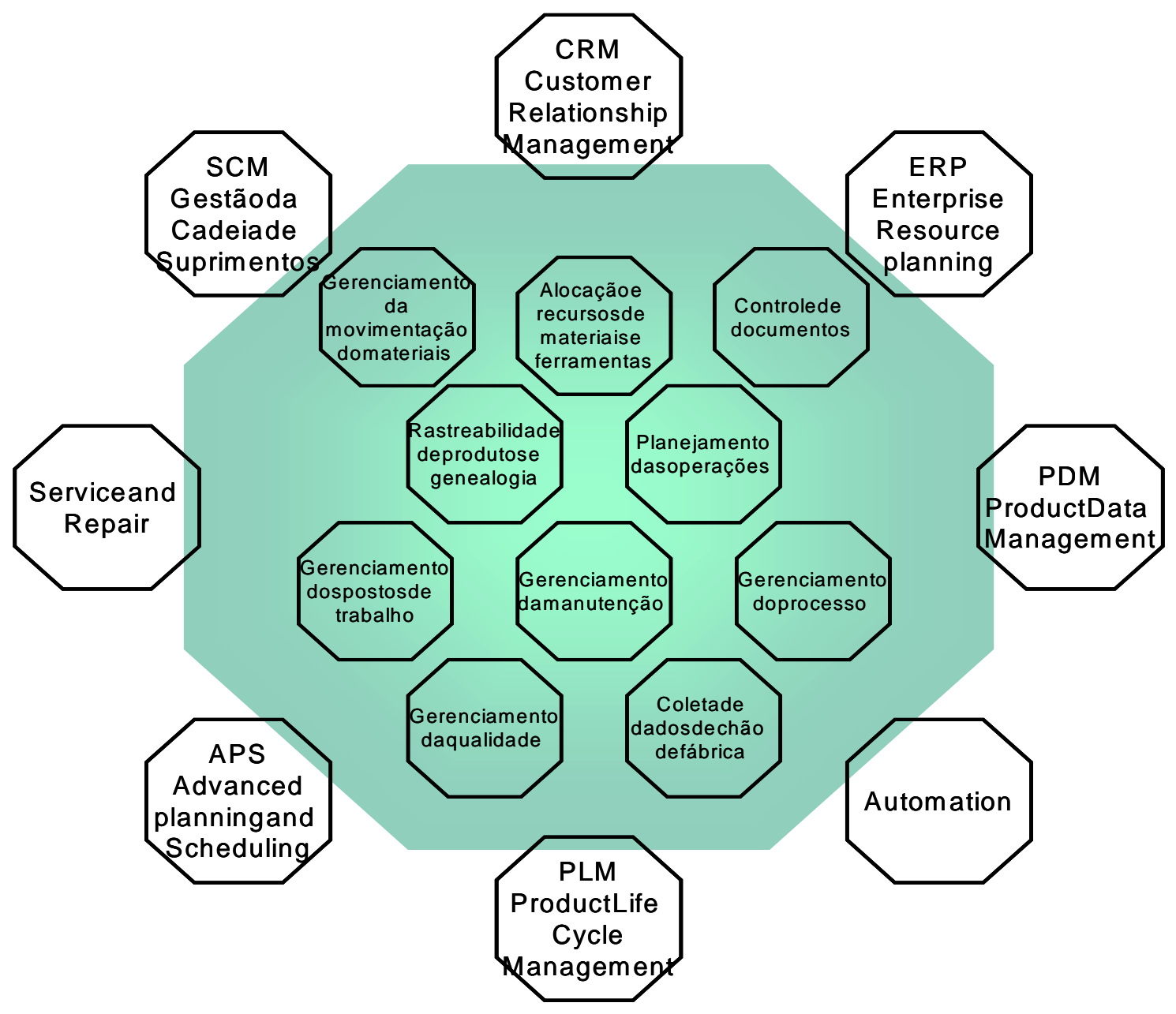

FIGURA 13 - Funcionalidades dos Sistemas MES

MELLO (2000)

\section{Gerenciamento da movimentação de materiais}

Gerencia o fluxo de produção na forma de ordens, batelada, lotes. Envia informações na seqüência em que as ordens necessitem serem executadas e altera em tempo real conforme os eventos ocorram no chão de fábrica. Gerencia retrabalho e controla a quantidade de estoque em processo em qualquer ponto através do gerenciamento dos buffers. 


\section{Gerenciamento da manutenção}

Rastreia e direciona atividades para garantir que máquinas e ferramentas estejam disponíveis para a produção e assegurar o agendamento de manutenção preventiva periódica, assim como resposta (alarmes) para problemas imediatos. Mantém histórico de eventos/problemas para diagnósticos futuros.

\section{Controle de documentos}

Controla relatórios e formulários que devem ser guardados junto à unidade de produção, incluem instruções de trabalho, desenhos, procedimentos padrões de produção, programas CNC, registros de lotes, notas de alterações de engenharia, assim como possibilitam a edição e registro de informações de montagem de equipamentos. Envia instruções para operações e controla documentações referentes a normas ambientais, saúde segurança e informações de registro para sistemas de qualidade, como procedimentos de ações corretivas e arquivamento de dados históricos.

A definição de sistemas MES abarca uma série de sistemas de objetivos diferentes, mas com a característica de apoio a Manufatura, no corpo deste projeto, adotar-se-á a visão de não se considerar os sistemas SFC (típica denominação dentro da "escola" MRP) ou sistemas PAC (nomenclatura muito utilizados pelos autores preocupados em definir arquiteturas de sistemas, baseados na arquitetura COSIMA) como sinônimo de MES, mas sim como exemplos de sistema MES. Pois o desenvolvimento deste trabalho leva a entender o conceito de MES como amplo de mais para ser tomado como sinônimo destes dois termos, estes sim, considerados no desenvolvimento deste trabalho como conceitos equivalentes entre si. O termo MES é então tomado como a denominação de uma série de sistemas, que abarcam desde sistemas de coleta de dados do tipo SCADA, quanto sistemas de planejamento finito, sistemas de gestão de dados de produção, 
sistemas para gestão da qualidade e outros ligados às operações de execução da manufatura.

\subsection{Sistemas SCADA}

Segundo a definição exposta por MEIRELLES (2000), sistemas SCADA (Supervisory Control and Data Acquisition) são sistemas compostos por um conjunto de ferramentas avançadas para atender as necessidades de gerenciamento de processos, possibilitando a comunicação com diversos outros sistemas sendo utilizados desde plantas industriais até automação predial. Através de um ou mais computadores ligados a uma rede de equipamentos eletrônicos de chão-de-fábrica, o sistema é capaz de fornecer uma 'foto' instantânea do processo monitorado, com as mais diversas informações (tais como: peças produzidas, tempo de máquina parada, motivos de parada, tempo de ciclo, etc...), além de poder, também, realizar o controle do processo em questão.

A utilização destes sistemas é muito comum em indústrias de processos contínuos, tais como petroquímicas, indústrias de alimentos e bebidas e indústrias de açúcar e álcool. Este fato é conseqüência da própria natureza destes processos que exigem monitoramento e controle em tempo real.

A arquitetura de um sistema de supervisão é composta por quatro elementos básicos: software de supervisão (SCADA); rede de comunicação; estações remotas de I/O e instrumentos de campo. As estações remotas, através da rede de comunicação, informam ao software de supervisão o status de cada um dos instrumentos de campo. O sistema de supervisão deve ser capaz coletar os dados e transformá-los em informações para o usuário em um tempo menor que os eventos possam ocorrer no chão-de-fábrica, de modo a permitir análises em tempo real e respostas eficientes a tais eventos (CAETANO, 2000). 


\subsection{Aplicação e Desenvolvimento de um Sistema de Monitoramento do Chão-de-Fábrica}

\section{Uma Arquitetura de Sistema Supervisório}

O sistema de monitoramento de chão-de-fábrica motivação deste trabalho é dividido em 5 módulos básicos (CAETANO, 2000):

$\checkmark$ Sensoriamento;

$\checkmark$ Rede de Campo;

$\checkmark$ Supervisão da produção (SCADA);

$\checkmark$ Repositório de informações da produção (Base de Dados)

$\checkmark$ Diagnóstico de Chão-de-Fábrica;

\section{Sensoriamento}

O módulo de sensoriamento engloba todos os equipamentos e dispositivos responsáveis por captar os das máquinas no chão-de-fábrica. São estes sinais que serão convertidos em informação útil a gestão da manufatura, sejam tecnológicos ou de dados de produção.

Estes equipamentos e dispositivos vão desde simples contadores de peças com acionamento mecânico até um CNC de última geração. Pode-se utilizar ainda utilizar-se leitores de código de barras, leitores de deslocamento, sensores de força, sensores de corrente, sensores de emissão acústica ou botoeiras para introdução de dados manuais no chão-de-fábrica. É interessante notar que a inteligente combinação de informações de sensores, com dados provenientes do CNC, é que possibilita a geração de uma grande gama de dados do sistema em estudo.

A coleta de sinais é feita em cada máquina individualmente. De posse da definição prévia de quais informações serão adquiridas do chão-de-fábrica (número 
de peças, tempos de ciclo e parada etc.), faz-se necessário o estudo da fenomenologia do processo em questão para definir quais sinais gerarão as informações solicitadas. Em seguida, define-se como esses sinais serão captados, seja por sensores ou por contatos secos do próprio painel elétrico da máquina.

\section{Rede de Campo}

A rede de campo é o componente do sistema de supervisão responsável por coletar os sinais provenientes do sensoriamento e transmiti-los para o software de supervisão.

Arquitetura da Rede:

Master da rede: controla o funcionamento da rede;

Módulos remotos de I/O: fazem a conexão com os equipamentos e dispositivos do módulo de sensoriamento;

Cabeamento: meio físico pelo qual os sinais são transmitidos;

Complemento: auxiliam o funcionamento da rede.

\section{Supervisão da Produção}

Os softwares responsáveis por interpretar os sinais, transformando-os em informações pertinentes são chamados de SCADA (Supervisory Control and Data Acquisition). Através deles, é possível fazer uma análise dos dados, avaliando informações como status da ordem de produção, tempos de ciclo, máquinas gargalos e demais informações que forem necessárias, uma vez que eles são capazes de fornecer uma imagem instantânea do chão-de-fábrica. Ele também é o responsável pela inserção e atualização dos dados no repositório de informações da produção (base de dados da produção). 


\section{Repositório de Informações da Produção (Base de Dados)}

Esse módulo é o responsável pelo armazenamento das informações da produção. Dessa forma, torna-se possível qualquer análise histórica da produção e comparações bem como a rastreabilidade de um determinado lote. É através desse módulo que é feita a integração do sistema de monitoramento da produção com as ferramentas, tais quais sistemas APS, ERP ou de Planejamento.

\section{Diagnóstico do Chão-de-Fábrica}

O módulo aqui chamado de diagnóstico de chão-de-fábrica, pode ser desempenhado por qualquer ferramenta computacional capaz de extrair informações relevantes sobre a base de dados operacional.

\subsection{Considerações sobre o Planejamento e Controle de Chão-de- Fábrica}

O papel do Planejamento e Controle de Operações no desempenho da manufatura é destacado na literatura (LINDAU, 1997; BANERJEE, 1997). Sendo o chão-de-fábrica o lugar onde as diretivas de qualquer sistema de planejamento são realmente postas a prova (HOPP \& SPEARMAN, 2001). Pois aqui, na gestão de chão-de-fábrica, podemos situar a função de um sistema SCADA, desempenhando o papel de Monitor, na estrutura apresentada por BAUER et al. (1991).

É possível se encontrar na literatura um razoável conjunto de modelos de referência para sistemas de chão-de-fábrica (MAGLICA, 1997; LEFRANÇOIS, 1996; SZELKE \& MÁRKUS, 1994; VAN BRUSSEL et al., 1999; GONG \& HSIEH, 1997), alternativos ou complementares aos aqui apresentados, contudo é onipresente a relevância que estes modelos dão ao papel da gestão de 
informações do status de produção para que se tenha um eficiente sistema de gestão de manufatura.

De maneira geral, os autores que se debruçam sobre os modelos para sistemas SFC, não apresentam detalhamentos maiores sobre como se dá a transformação dos status de chão-de-fábrica em eventos de manufatura na forma de informações disponíveis aos sistemas de chão-de-fábrica.

LINDAU (1997) aborda a coleta de dados de chão-de-fábrica automatizada na manufatura discreta. Este estudo mostra que basicamente esta coleta de dados é feita de dados de planejamento e não de dados de programação. Depreende-se daí que é pressuposto o entendimento das características das informações coletadas no nível de operação diferem marcadamente entre si, dependendo do nível de planejamento em que serão utilizadas, se para o nível de planejamento ou de programação, contudo estes dois tipos de informação apresentam um requisito comum fundamental e de difícil obtenção: a necessidade de qualidade na informação para um bom desempenho; e que a maior parte destas informações é gerada e obtida no nível operacional. Esta diferença entre informações de planejamento e programação pode ser vista segundo outro aspecto, as informações de planejamento são tipicamente informações para atualização e mudança de planos de médio e longo prazo, como informações sobre tempos de operação, freqüências de eventos, grau de utilização de recursos, registros de eventos, volumes de produção e históricos de ordens, sendo o objetivo principal deste tipo de informação o de detectar desvios nos planos de médio e longo prazo. As informações de suporte ao planejamento e programação (reprogramação) de curto prazo devem ser direcionadas ao controle de produção, ou melhor dizendo, informações utilizadas para uma reprogramação eficiente frente a eventos inesperados. Este tipo de informação contém o status atual dos recursos 
(máquinas, homens, materiais, informações, dentre os principais), possibilitando assim a determinação de prioridades de ordens de produção e a tomada de ação frente aos distúrbios de produção, de forma a possibilitar que se evite a propagação destes distúrbios pelo ambiente de produção.

MAGLICA (1997) e VAN BRUSSEL et al. (1999) reputam que a estrutura dos modelos funcionais de sistemas de planejamento e controle de chão-de-fábrica baseados na arquitetura COSIMA, como o modelo apresentado por BAUER et al. (1991) apresentam como falha principal a excessiva hierarquização do fluxo de informações e propõem a utilização de modelos de sistemas com um grau de autonomia maior, preconizando a comunicação de dados entre os níveis de célula, garantindo maior confiabilidade ao sistema.

O grande hiato que existe nos ambientes de manufaturam, mesmo existindo a coleta de dados automatizada consiste na falta de conexão destes dados com sistemas de programação de produção. Os dados até são coletados, porém sua utilização de maneira a melhorar a qualidade da programação de produção é apenas indireta. A "ligação perdida" da coleta de dados automatizados para sua utilização otimizada é com os sistemas de programação de produção (LINDAU; 1997).

A utilização de um sistema de coleta de dados de chão-de-fábrica proposta por CAETANO (2000) e MEIRELES (2000) mostra-se fundamental aos sistemas SFC, desempenhando o papel que no modelo de BAUER et al. (1991) é atribuído ao Monitor, proporcionando acesso direto aos dados de programação através de conexão direta aos equipamentos de produção. Os sistemas de coleta de dados apresentados na literatura, aplicados a sistemas de manufatura job shop, coletam informações indiretas, ou seja, através de códigos de barras ou radio freqüência ou dados de apontamento de operadores. Estas informações não dão a visibilidade 
que um sistema integrado ao comando numérico dos equipamentos, modelado conjuntamente com a coleta de códigos de barras, sensores e rádio freqüência podem dar. Tal grau de integração só pode ser integrado no nível de células FMS e ambientes CIM, ao contrário do sistema SCADA aplicado a célula de manufatura do NUMA da Escola de Engenharia de São Carlos, que têm uma aplicabilidade muito maior, visto ao já alto grau de utilização de máquinas CNC na indústria, que pode ser integrado a coleta de dados por sensores, botoeiras e código de barras em um parque de manufatura híbrido entre máquinas de comando numérico, mecânicas e células de montagem.

BANERJEE (1997) aponta que a maior parte das empresas (70\%) não se considerava apta à utilização de sistemas de programação de produção. Este mesmo estudo aponta que a grande maioria das empresas percebe o grande potencial de melhoria que a introdução de sistemas de planejamento e controle de produção podem ter no desempenho ( $70 \%$ das empresas pesquisadas), contudo parecem não considerar os investimentos neste tipo de sistemas de fácil retorno frente ao investido (apenas 6\% das empresas consideravam investimentos nesta área).

McKAY \& BUZACOTT (2000) afirmam que a programação e controle de produção de produção em ambientes job shop é um problema demasiadamente complexo para que seja passível de boa solução através de soluções analíticas ou por algoritmos.

Assim uma solução de sistema voltada à gestão de chão-de-fábrica deve contemplar uma abordagem que inicialmente determine adequadamente os objetos de manufatura e a partir desta modelagem analise o processo de programação e controle de produção de forma a contemplar o auxílio ao processo de programação 
e controle de produção, segundo a perspectiva das pessoas que efetuam esta atividade, os programadores. 


\section{Conclusões e encaminhamento}

O tema deste trabalho foi o de estudar o planejamento de produção nas empresas de manufatura, em especial das empresas de manufatura discreta, de forma a estudar as possibilidades de utilização de sistemas supervisórios SCADA proposto pelos trabalhos de CAETANO (2000) e MEIRELLES (2000).

Este trabalho explorou os aspectos chaves dos principais modelos de planejamento e controle de produção, de forma a contextualizar o papel da coleta de dados, frisando a lacuna atual existente nestes modelos de propostas para a coleta de dados eficiente. O que significa a correta diferenciação entre os dados que permitem que se obtenha dados utilizáveis para a dimensão de Planejamento e para a dimensão de Programação e Controle de Produção.

O trabalho leva a enfatizar no projeto a contextualização do impacto dos sistemas supervisórios segundo a classificação de sistemas de manufatura, seguindo o caminho do estudo de adequação de relacionamento dos sistemas de Planejamento e Controle de Produção, assuntos estes abordados por PORTER et al. (1999) e em TATSIOPOULOS (1997), que desdobram as ligações entre as várias classificações de manufatura e suas ligações com o sistema de Planejamento e Controle de Produção, entendo-se aqui não só segundo a classificação das técnicas clássicas de (JIT, MRP e TOC), mas de uma forma abrangente sobre as diferenciações destes sistemas e principalmente sobre o papel que os sistemas de planejamento e controle de chão-de-fábrica têm no sucesso dos sistemas de planejamento das indústrias de manufatura discreta.

Para uma efetiva implementação de um sistema de manufatura, é fundamental a consideração da utilização um sistema de planejamento e controle de chão-de-fábrica. A abordagem assumida neste trabalho considera que a 
definição de tal sistema deve considerar não só os componentes de hardware e software que venham a compor um sistema, mas deve sobretudo considerar as atividades e decisões realizadas pelas pessoas que interagem dentro deste sistema, para a obtenção de um desempenho efetivo.

Assim é proposto um roteiro a ser seguido que contemple a definição e desenvolvimento de um sistema voltado ao chão-de-fábrica, suportado por um sistema de coleta de dados automático, contextualizando os pontos onde um sistema SCADA proposto por CAETANO (2000) e MEIRELES (2000) pode e deve ser utilizado.

\subsection{Fase de Diagnóstico do Sistema de Manufatura}

Esta fase deve contemplar o levantamento de quais são os parâmetros externos e internos da empresa que condicionam o sistema de manufatura, então as considerações de TATSIOPOULOS (1997) servem como útil ponto de referência para o entendimento de como o ambiente e as condições do sistema de manufatura influenciam no sistema de planejamento e controle de produção de todos os níveis. Assim parâmetros como grau de padronização dos produtos, estrutura dos produtos, fluxo de processo e layout; devem ser levantados e relacionados com o processo de gestão de produção, para que se compreenda como estas condições influenciam o sistema de planejamento. É importante aqui entender estes parâmetros e definir como um sistema de coleta de dados deve se encaixar com este cenário para prover as informações necessárias para um sistema de planejamento de produção.

Vale aqui também a preconização do entendimento da influência da demanda no ambiente de produção, segundo a perspectiva Make-to-Stock, Assemble-to-Order, Make-to-Order, Engineering-to-Order e Design-to-Order. Pois 
embora a utilização de topologia de sistema de produção tenha sido sobrevalorizada na sua influência na determinação dos sistemas de planejamento de produção nos últimos anos (ARTIBA \& ELMAGHRABY, 1996), a compreensão de que a realidade dos sistemas de manufatura é a de que a influência da demanda no planejamento normalmente é híbrida, com diferentes linhas de produtos estando sujeitas a diferentes tipos de demanda, estando a maior parte das vezes compartilhando os mesmos recursos. Tendo em mente que o normal seja encontrar tais ambientes sujeitos a influências mistas de demanda, previne-se a tendência de valorizar demasiadamente a influência da característica de demanda na determinação do modelo de sistema de planejamento.

Esta fase de determinação de um sistema deve avaliar não só o que condiciona o sistema de manufatura hoje, mas sim, também o que pode vir a condicionar o sistema no futuro. O levantamento dos requisitos de negócios pode mudar, a tecnologia de processo também, os segmentos de mercado que uma empresa atende normalmente também se alteram com o tempo. As empresas hoje tendem a procurar evoluir de um sistema de produção em massa, para um modelo de maior diferenciação de produtos, assim as empresas que operam segundo um modelo predominante MTO tendem a caminhar em direção a um modelo Customized-to-Order, onde é possível amenizar a incerteza da demanda por previsão. Isto têm implicações diretas na manufatura, pois acentua a tendência de produção em lotes menores e pressiona pela redução de estoques e dos custos associados a estes estoques, que em um contexto de curtos ciclos de desenvolvimento de produtos e alta taxa de introdução de novos produtos, representam um grande investimento em estoques e alto risco de perecibilidade.

Nesta fase já é possível relacionar quais são os requerimentos empresariais e quais são as medidas de desempenho importantes ao negócio. Então é possível 
já desenhar qual o papel que um sistema de coleta de dados pode ter. Assim é importante obter as respostas às perguntas como quais são indicadores de desempenho da manufatura serão necessários? Quais serão os indicadores de qualidade, de eficiência operacional (disponibilidade de equipamento, paradas de equipamento, tempos de fila, fluxo, de ciclo), de custos, de atendimento de prazos? Donde decorre o mais importante no contexto deste trabalho, como serão coletados estes dados e qual o nível de confiabilidade necessário.

Não menos importante é a avaliação do sistema social que rege as relações na empresa. Qual o nível de qualificação da mão-de-obra, qual é a interação das pessoas nas decisões de planejamento e programação. Como é a cultura da empresa de gestão das operações.

Cabe por fim, a análise do histórico de desempenho, cujo objetivo é o de responder quantitativamente como as operações atuais respondem aos eventos inesperados, como se propagam as perturbações no sistema. Qual foi o efeito histórico de uma ordem de venda adiantada, uma entrega que chegou atrasada ou na quantidade errada, uma quebra de máquina. Estes dados são um indicativo fundamental de como é a dinâmica de produção e de como um sistema de planejamento e controle deve responder aos problemas de produção.

Podemos resumir este check-list no levantamento das seguintes dimensões de informação: Informações de Mercado, Informações de Produto, Informações de Tecnologia de Processo, Informações do Sistema Cultural, Informações de Desempenho de Manufatura e Informações de Requerimentos Empresarias.

A tabela 5, sumariza as dimensões em que as informações obtidas nesta fase podem ser dividas e apresenta alguns fatores que podem ser determinados para cada dimensão. 
Cabe aqui, a consideração de PORTER et al. (1999) de que a maneira como a empresa escolhe para se organizar e as características de mercado em que ela atua são predominantes no delineamento de um sistema de planejamento de produção e de que pode não ser apropriado a escolha de um fator único determinante na construção de um sistema de planejamento, sendo muitas vezes mais adequado a opção de considerar modelos híbridos na definição dos sistemas.

TABELA 5 - Dimensões de Informação no Diagnóstico de um Sistema de Manufatura

\begin{tabular}{|l|l|}
\hline \multicolumn{1}{|c|}{$\begin{array}{c}\text { DIMENSÕES DE } \\
\text { INFORMAÇÃO }\end{array}$} & \multicolumn{1}{c|}{ FATORES } \\
\hline Mercado & $\begin{array}{l}\text { Características de interação com demanda (ex: MTO, } \\
\text { ETO); sazonalidade; tempos de entrega; custos; } \\
\text { qualidade. }\end{array}$ \\
\hline Produto & $\begin{array}{l}\text { Níveis de estrutura do produto; freqüência de alterações } \\
\text { de engenharia; complexidade; tolerâncias. }\end{array}$ \\
\hline $\begin{array}{l}\text { Tecnologia de } \\
\text { Processo }\end{array}$ & $\begin{array}{l}\text { Grau de automação dos equipamentos; grau de } \\
\text { diversidade de tecnologias; fluxo do processo; viabilidade } \\
\text { de conexão de equipamentos com um sistema de coleta } \\
\text { de dados. }\end{array}$ \\
\hline Sistema Cultural & $\begin{array}{l}\text { Nível de treinamento dos operadores; grau de disposição } \\
\text { a mudança; motivação. }\end{array}$ \\
\hline $\begin{array}{l}\text { Desempenho de } \\
\text { Manufatura }\end{array}$ & $\begin{array}{l}\text { Histórico de desempenho; reação a eventos } \\
\text { inesperados; qualidade dos dados disponíveis. }\end{array}$ \\
\hline $\begin{array}{l}\text { Requerimentos } \\
\text { Empresariais }\end{array}$ & $\begin{array}{l}\text { Quais os objetivos da empresa para a manufatura; quais } \\
\text { os indicadores de desempenho relevantes; quais as } \\
\text { melhorias esperadas. }\end{array}$ \\
\hline
\end{tabular}


5.2 Fase de Desenvolvimento de um Sistema de Planejamento e Controle

Aqui devem ser respondidas as questões sobre qual tecnologia de programação deve ser usada, qual tecnologia de comunicação de dados, qual será o modelo de dados, como modelar o processo, como deve ser a interface homemsistema. Como será a integração do sistema desenvolvido com os outros sistemas da empresa, qual a capacidade de mudança do sistema devido a uma mudança de prioridade da empresa, de mercado, de tecnologia de produção. Qual a capacidade de expansão das funcionalidades do sistema e capacidade de reutilização em outros ambientes, quais técnicas de programação e sequenciamento são adequadas.

A proposta é que nesta fase, consideremos as seguintes dimensões (Figura 14):

Definição do Domínio do Chão-de-Fábrica: fase em que devem ser levantados os objetos de manufatura, o que implica no reconhecimento das tecnologias do processo produtivo. Neste momento se faz necessário definir e propor como a coleta de dados de chão-de-fábrica deve ser feita e a análise da aplicação de um sistema SCADA deve ser considerada. 


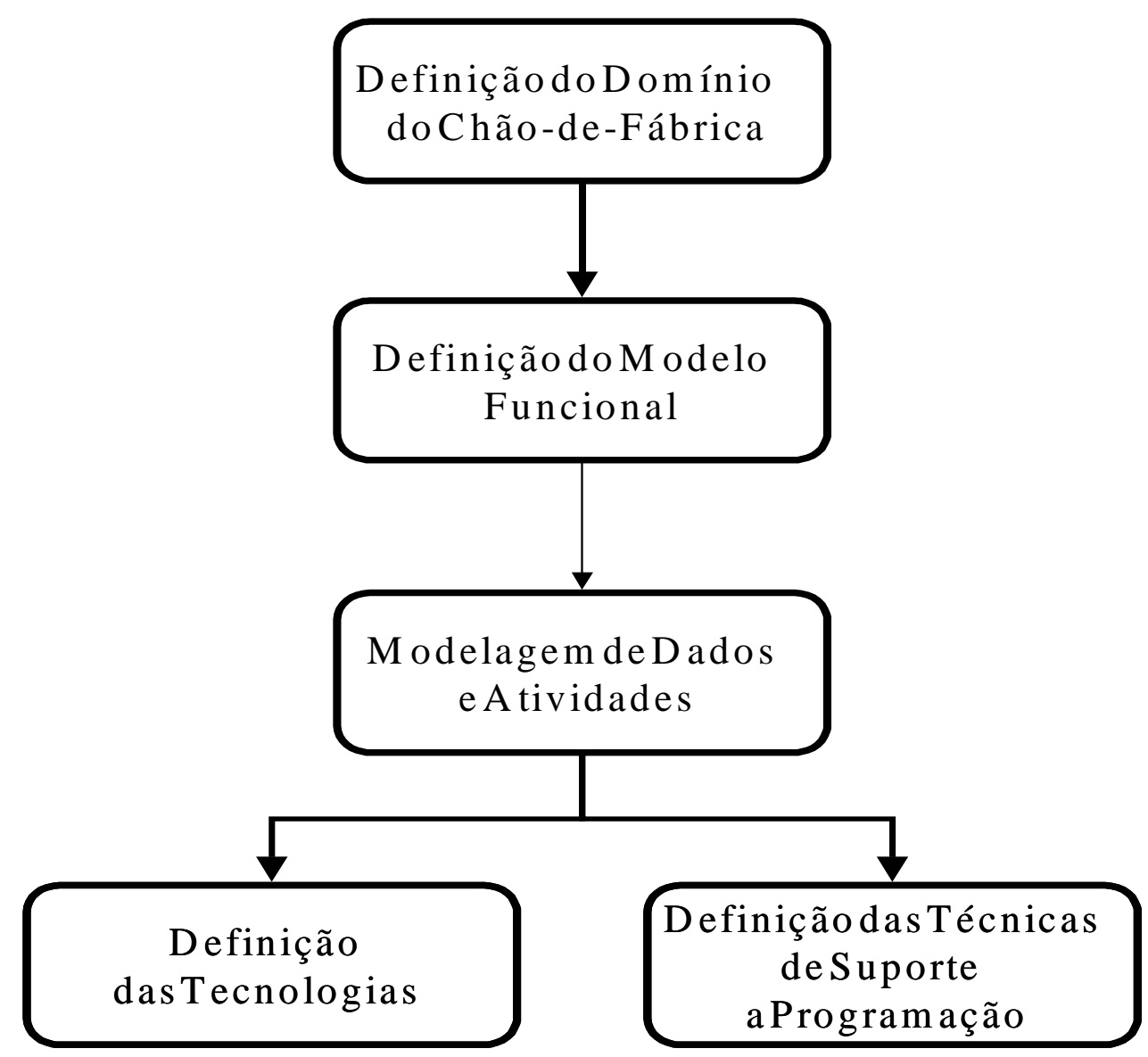

FIGURA 14 - Atividades no Desenvolvimento de um Sistema de Planejamento e Controle de Produção

Nesta fase a aplicação da categorização proposta por ZHANG et al. (1996) é muito útil para o reconhecimento e categorização dos objetos de manufatura (categoria equipamentos, categoria recursos e categoria sistemas).

O reconhecimento destes objetos e o levantamento das possibilidades tecnológicas de coleta de dados, seja através de comando numérico, sensores, radiofreqüência, código de barras ou tags magnéticos é fundamental para o sucesso da implementação do sistema, tendo.

Banerjee (1996) ressalta a necessidade de identificação destes objetos de manufatura (Figura 15) e sua compreensão, analisando a adequação para 
implementação de sistemas SCADA, é o que pode garantir o sucesso da função de coleta de dados em um sistema SFC.

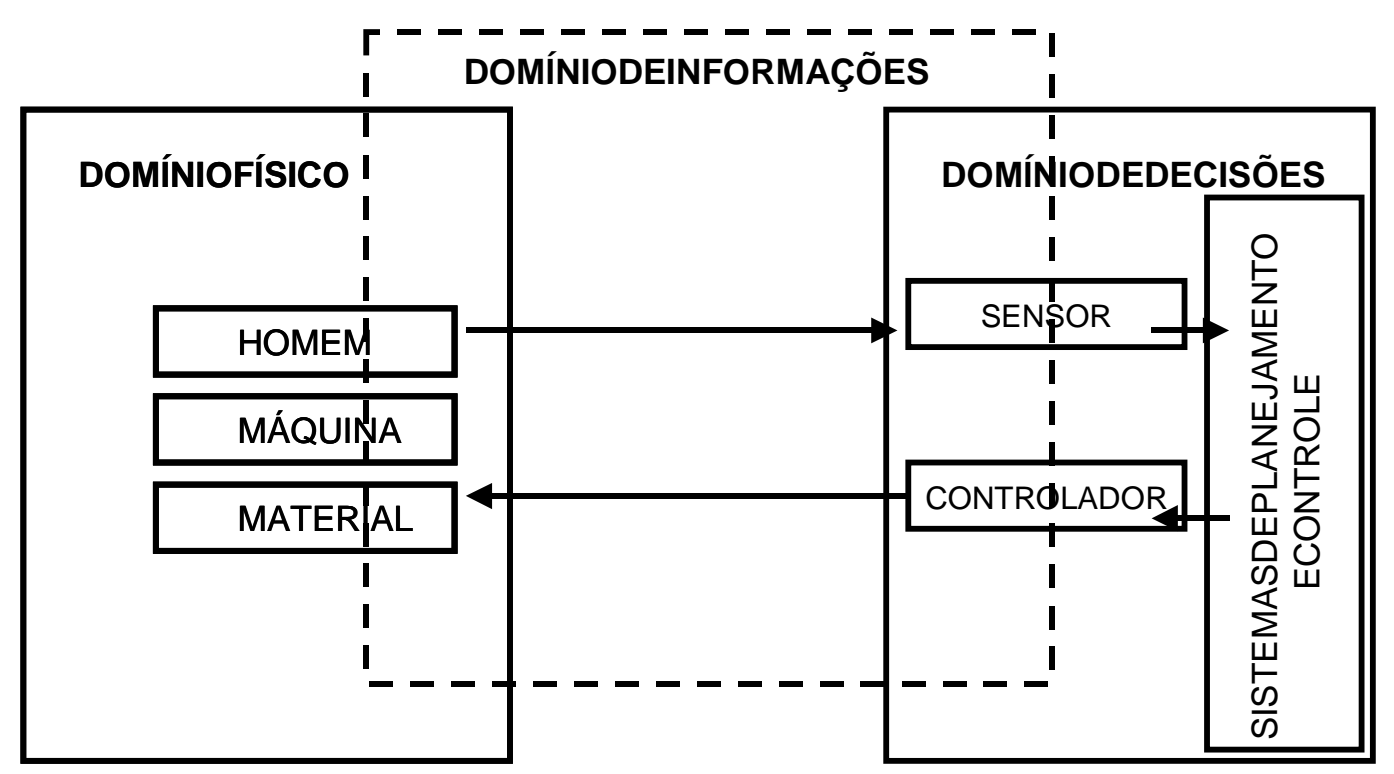

FIGURA 15 - Relacionamento Domínio Físico da Manufatura e Sistemas Adaptado de BANERJEE (1997)

Definição do Modelo Funcional do Sistema: aqui devem ser determinados os blocos funcionais, que devem ser mapeados e definidos, para execução automatizada, execução suportada por computador ou inteiramente feita por pessoas.

Esta fase define o sistema, tanto no plano lógico-funcional quanto no detalhamento dos requisitos de software e hardware.

Os modelos de BAUER et al. (1991), TATSIOPOULOS (1997) e MAGLICA (1997), são excelentes pontos de partida para estruturação funcional de um sistema SFC. O reconhecimento da necessidade de mecanismos de programação, liberação e monitoramento, juntamente com a estruturação em três classes de problemas distintos, com os quais um sistema de gestão de chão-de-fábrica deve 
lidar: Gestão de Materiais; Gestão de Capacidade e Gestão de Ordens. Pode-se ainda assumir uma abordagem menos hierarquizada, onde o fluxo de informações não se atenha apenas no de coordenação das prioridades em função das diretrizes dos sistemas de planejamento de mais alto nível, mas uma abordagem mais colaborativa entre os diferentes sistemas PAC, representando uma estrutura mais horizontal, onde informações sejam trocadas entre os diferentes sistemas PAC de diferentes células de manufatura (AGUIRRE et al., 1999; MAGLICA, 1997; VAN BRUSSEL et al., 1999).

O central nesta etapa é a adequada avaliação da adequação dos modelos a realidade e aos condicionantes levantados na fase de diagnóstico. Muito da flexibilidade a mudanças e escalabilidade técnica, são também definidas através da especificação dos blocos funcionais.

A avaliação dos níveis hierárquicos de decisão e da distribuição de tarefas, determina e muito o desenvolvimento da solução tecnológica e vice-versa. 
5.2.1 Modelo Funcional de Sistema de Planejamento e Controle de Chãode-fábrica proposto

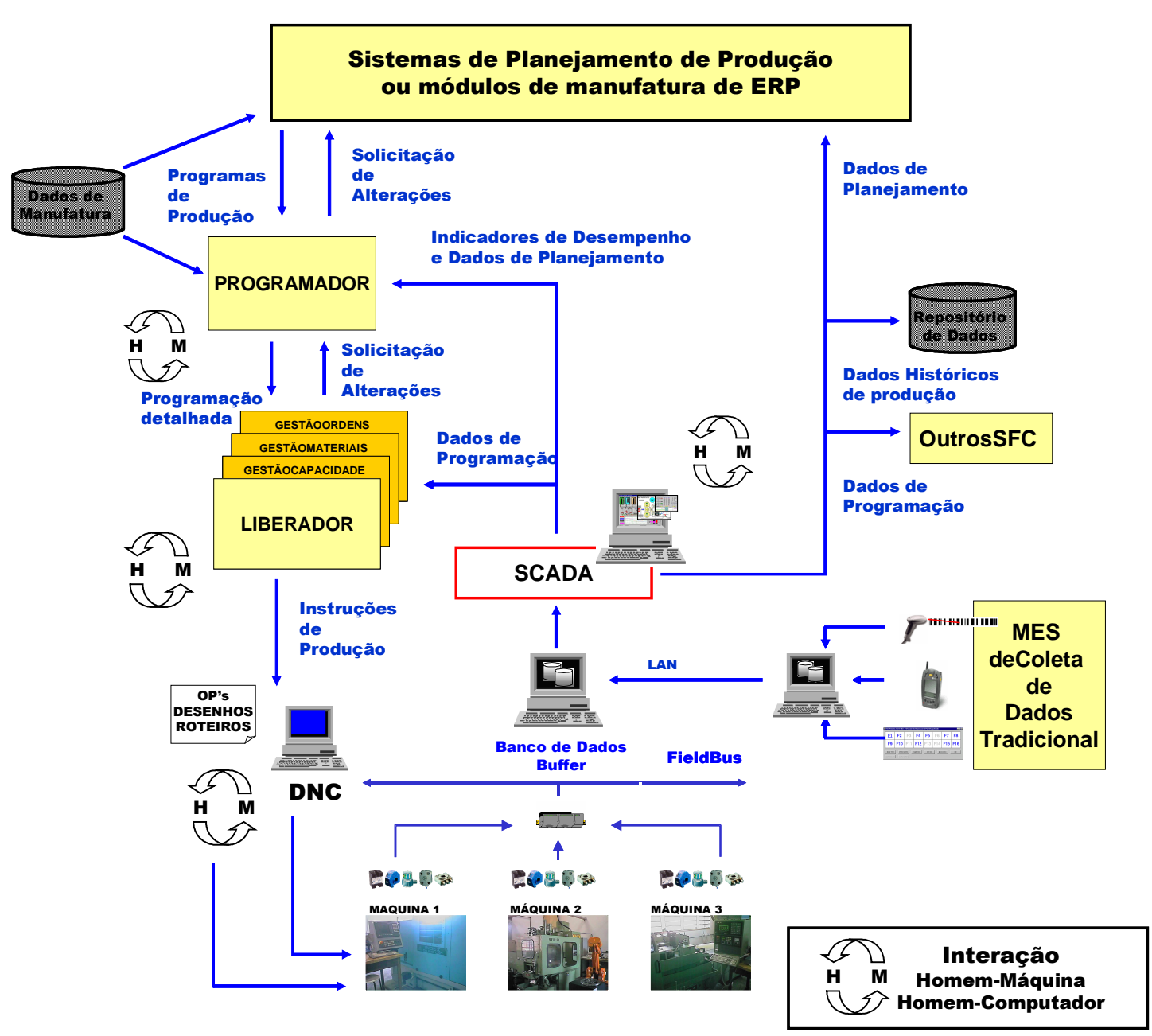

FIGURA 16 - Modelo funcional de Sistema SFC

A Figura 16 é proposta como arquitetura de integração de uma implantação de sistema de planejamento e controle de chão-de-fábrica baseada no modelo de BAUER et al (1991), integrado com sistemas de planejamento de produção de mais alto nível, mostrando a utilização do sistema SCADA proposto por CAETANO(2000) e MEIRELES (2000), desempenhando o papel de Monitor no modelo de BAUER (1991). 
Este modelo proposto incorpora a utilização de um banco de dados intermediário, propostos por CAETANO (2000) e MEIRELES (2000), desempenhando uma função de MES, junto ao supervisório de maneira a manter a consistência dos dados entre o sistema supervisório e as camadas superiores e retendo uma quantidade sumarizada, dado a grande quantidade de dados possíveis de serem gerados por um supervisório. Esta camada faz necessária para manter um repositório buffer de dados que retenha por um determinado período de tempo os dados gerados pelo sistema SCADA, dando maior independência de conexão com os outros módulos de uma arquitetura de sistema SFC e ainda permite que haja uma conexão com outros módulos "Liberadores" de outras células de manufatura, incorporando a proposta de MAGLICA (1997), de aprimoramento do modelo proposto por BAUER et al. (1991), para um modelo mais colaborativo de programação, com troca de dados entre as camadas de mais baixo nível, possibilitando um planejamento mais colaborativo (VAN BRUSSELS et al., 1999) .

O fluxo de informações entre o Liberador e a camada de execução enfatiza que este fluxo de comunicação de dados pode ser externo ao sistema computacional, através de documentos e instruções interpretadas por supervisores e operadores. A interação entre o SCADA e o Liberador, constituí principalmente de dados de programação (LINDAU, 1997), onde o Liberador desempenha o papel de programador fino de produção, considerando as restrições de capacidade, materiais e ordens. Aqui cabe também a função do Liberador como gestor de documentação do chão-de-fábrica, razão porque aparece a conexão com banco de dados de informações de dados de manufatura com o Programador, pois usualmente dados como desenhos, programas de controle numérico, especificações de qualidade, encontram-se externos ao sistema. 
O Programador aparece como uma camada de programação de mais alto nível, que recebe dados de uma rodada MRP e converte em propostas de programação dentro do horizonte fixo do MRP. A grande diferença entre um módulo Programador e um Liberador, constitui que o Programador tenta integrar os sequenciamentos, suportando simulações, entre as diversas células de trabalho e o Liberador tem seu foco no sequenciamento da célula de manufatura, só acessando o Programador, conforme seja detectado violar alguma regra que necessite alterações de restrições que impliquem em alterações de programas em outras células.

É desejável que o horizonte de tempo seja diferente entre estes dois módulos, com o Liberador tratando de sequenciamentos e questões de capacidade de curto prazo e o Programador também lidando com programas que atinjam o horizonte de tempo de médio prazo. O Liberador incorpora também do modelo de TATSIOPOULOS (1997), a presença das camadas de Gestão de Ordens (documentação de ordens, dimensionamento de lotes), Gestão de Capacidade (disponibilidade e controle de capacidade, através de algoritmos e suporte a simulação) e Gestão de Materiais (avaliação de disponibilidade de materiais, regras de escolha materiais alternativos).

Este modelo sugere ainda uma maior interação entre o sistema de chão-defábrica e os sistemas de planejamento de nível hierárquico superiores, através da retro-alimentação de informações entre o Programador e os sistemas de planejamento ou módulos de manufatura de sistemas integrados.

O modelo sugere a existência de um banco de dados de registro dos dados coletados, do banco de dados buffer existente junto ao SCADA, para que possibilite o registro dos dados principais coletados pelo SCADA, tanto para possibilitar a utilização de indicadores de desempenho, quanto o estudo do desempenho de 
produção, possibilitando estudos exploratórios sobre dados de produção (FAVARETTO, 2000).

Modelagem de Dados e Atividades: aqui deve se utilizar alguma técnica de modelagem estruturada, objetivando a modularidade e flexibilidade que um sistema deste tipo deve ter frente a alterações nas definições que o domínio de dados levantados no passo anterior possa sofrer. Mais importante do que a técnica de modelagem em si, tem sido o bom entendimento do processo produtivo e a adequação a realidade da empresa, havendo várias técnicas estruturadas disponíveis a modelagem de processo, como SADT (Structured Analysis and Design Technique)(BAUER et al., 1991; ZANG et al., 1996; TATSIOPOULOS, 1999), IDEF0 (Integrated Computer-Aided Definition method Zero)(BANERJEE, 1997; GONG \& HSIEH, 1997), ou EPC (Event-driven Process Chain)(FAVARETTO, 2000). Para a modelagem de dados, predomina a utilização das variações do Modelo Entidade-Relacionamento, derivado das técnicas de Análise Orientada a Objetos.

Definição das Técnicas de Suporte a Programação e sequenciamento: nesta etapa, deve-se utilizar a abordagem de modelagem voltada ao suporte as atividades de programação, reconhecendo que a principal tarefa de um sistema de controle de chão-de-fábrica é suportar as atividades do programador de produção, reconhecendo a complexidade da aplicação de regras completamente automatizadas e a capacidade do programador de relaxas as restrições dos programas de programação.

Portanto deve ser feita a análise da viabilidade da utilização de regras de programação, métodos analíticos e técnicas de simulação que suportem as atividades de programação da produção caracterizando um sistema de programação com capacidade finita. 
SZELKE \& MARKUS (1991) destacam os seguintes pontos que devem ser considerados na definição de um sistema de programação: identificação do status de processo que devem ser informados ao sistema e identificação das comparações necessárias a geração de informações e o conseqüente delineamento do processo de tomada de decisão frente a eventos que possam afetar a execução dos planos; controle da alocação de ordens.

É relevante neste momento considerar que a desestruturação dos problemas de manufatura discreta, impede a solução ótima dos problemas de programação através de regras, heurísticas e métodos analíticos. O papel de um sistema de planejamento e controle de produção de produção deve ser o de suportar as decisões do programador, resolvendo os problemas mecanicísticos, provendo informações de status, relatórios de alerta a eventos e suportando simulações.

Então se propõem que na fase de análise da utilização de sistemas de apoio ao processo de programação, se considere como um sistema SFC pode suportar o processo de programação realizado pelo pessoal de fábrica, proposto por McKAY \& BUZACOTT (2000), onde aponta-se os pontos principais onde a aplicação de um supervisório pode ser utilizado (Figura 17). 


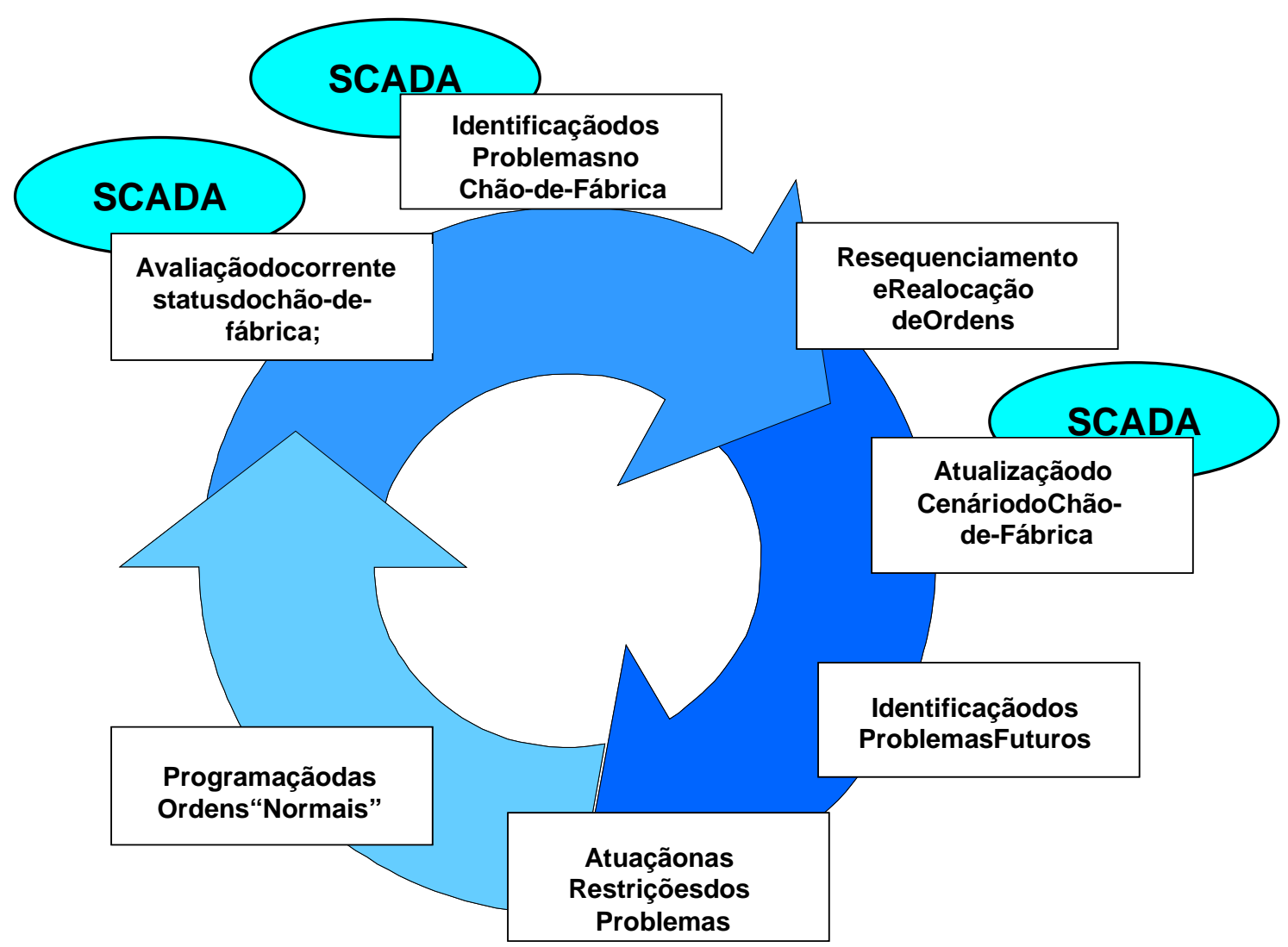

FIGURA 17 - Suporte do SCADA ao Processo de Programação

A utilização de um sistema SCADA integrado a equipamentos CNC, têm uma aplicação fundamente na coleta de dados de produção para prover suporte às atividades de avaliação do status de chão-de-fábrica, identificação de problemas, que possibilitam o resequenciamento, seja ele suportado por um sistema de FCS ou manual e na reavaliação deste status.

Definição das Tecnologias de Informação: Aqui devem ser levantadas as questões tecnológicas, como quão modular deve ser o sistema, quais padrões devem ser utilizados, escolha dos protocolos de comunicação, formatos de troca de dados, configurações de rede, comunicação com dispositivos de equipamentos, camadas de integração necessárias. 
No aspecto tecnológico, cabem aspectos que impactam diretamente o funcionamento de um sistema de SFC. A implementação de funções de programação finita, torna-se extremamente dependente da disponibilidade e velocidade da atualização de dados. As escolhas feitas aqui, também vão impactar fortemente a capacidade de um sistema deste tipo terá para evoluir conforme as mudanças do ambiente de manufatura, tanto tecnológico quanto de negócios (ANDERSSON, 1997).

Flexibilidade de manutenção e evolução e capacidade de integração são os requerimentos fundamentais dos resultados das definições feitas nesta fase.

\subsection{Considerações sobre Trabalhos Futuros}

A continuidade de trabalhos na área de aplicação de sistemas supervisórios no Planejamento e Controle de Produção deve ter uma abordagem de pesquisa de campo que investigue os condicionantes específicos de uma empresa, para a implantação de tal configuração de sistemas, alertando para os perigos das tentativas de se tentar enquadrar uma empresa a um modelo de referência quando dentro da mesma empresa ou planta fabril convivem diferentes modelos (BANERJEE, 1996), tentativa esta que residiu muitas vezes na falta de aderência de um modelo de sistema de planejamento a realidade das empresas, quando da implantação de sistemas MRP e de outros sistemas de manufatura.

Assim propõem se que exista uma abordagem que analise a aplicação prática da configuração de sistemas de Planejamento e Controle de Produção, com sistemas supervisórios, em aplicação de sistemas de planejamento de capacidade finito e de sua interação com o processo de programação executado pelo pessoal de chão-de-fábrica e seu impacto com os outros processos da empresa (financeiro, vendas, suprimentos e logístico). 


\section{Referências Bibliográficas}

APQC - AMERICAN PRODUCTIVITY AND QUALITY CENTER. (1998). Process Classification Framework. http://www.apqc.org (18/07/2001).

AGUIRRE, A.; WESTON, R.; MARTIN, F.; AJURIA, J.L. (1999). MCSARCH: An architecture for the development of manufacturing control systems. International Journal of Production Economics, v.62, p.45-59.

ALVAREZ, R.R.; ANTUNES JR, J.A.V. (2001). Tackt-time: Conceitos e contextualização dentro do sistema Toyota de Produção. Gestão \& Produção, v.8, n.1,p.1-18.

ALVORD III, C.H. The S in APS. IIE Solutions, October 1999, p.38-41. Institute of Industrial Engineers.

ANDERSSON, N. (1997). Design Principles for open and reusable shop-floor control software. Computers in Industry, v.33, p.285-293.

ARTIBA, A.; ELMAGHRABY, S.E org. (1996). The planning and scheduling of production systems: methodologies and applications /Editorial, London, Chapman \& Hall.

BANERJEE, S.K. (1996) Methodology for integrated manufacturing planning and control systems design. In: ARTIBA, A.; ELMAGHRABY, S.E org. (1996). The planning and scheduling of production systems: methodologies and applications /Editorial, London, Chapman \& Hall, Cap.3, p.54-88.

BAUER, A.; BOWDEN, R.; BROWNE, J.; DUGGAN, J.; LYONS, G. (1991). Shop Floor Control Systems: From design to implementation. London, Chapmann \& Hall. 
BONNEY, M. (2000). Reflections on production planning and control (PPC). Gestão \& Produção, v.7, p.181-207, dez.2000.

BROWNE, J.; HARHEN, J.; SHIVNAN, J. (1988). Production Management Systems: a CIM perspective. Galway, Addison-Wesley.

CAETANO, A. G. L. S. (2000), Sistemas de supervisão de chão-de-fábrica: uma contribuição para implantação em indústrias de usinagem. São Carlos. 161p. Dissertação (mestrado), Escola de Engenharia de São Carlos, Universidade de São Paulo.

CAETANO, A.G.L.S.; MEIRELES, G.S.C.; OLIVEIRA, J.F.G; SOUSA, G.W.L; Informações de Chão-de-Fábrica num ambiente de Manufatura Integrada, In: Congresso e Exposição Internacionais da Engenharia da Mobilidade, 8o., São Paulo, 1999, SAE do Brasil.

CHIAVENATO, I. (1991). Iniciação a administração da produção. São Paulo. McGraw-Hill: Makron Books.

CHIAVENATO, I. (1993). Introdução a teoria geral de administração. São Paulo. McGraw-Hill: Makron Books.

CONTADOR, J.C.; CONTADOR, J.L. (1997). Programação e Controle para a indústria intermitente. In: CONTADOR, J.C., coord. Gestão de Operações. São Paulo. Edgard-Blucherd/Fundação Vanzolini.

CORRÊA, H.L.; GIANESI, I.G.N. (1993). Just-in-Time, MRP e OPT: um enfoque estratégico. $2^{\circ}$.ed. São Paulo, Atlas.

CORRÊA, H.L.; GIANESI, I.G.N.; CAON, M. (1997). Planejamento, programação e controle da produção: MRP II/ERP : conceitos, uso e implantação. São Paulo, Atlas. 
FLEURY, M.T.; FLEURY, A.C. (1995). Aprendizagem e Inovação Organizacional. São Paulo, Atlas.

GAITHER, N.; FRAZIER, G. (1999). Administração da Produção e Operações. São Paulo. Pioneira Thomson Learning.

GIL, A.C. (1991). Métodos e técnicas de pesquisa social. São Paulo. Cortez.

GOLDRATT, E.M.; COX, J. (1993). A Meta. São Paulo. Educator.

GONG, D.; HSIEH, Y. (1997). Conceptual design of a shop floor control information system. International Journal of Computer Integrated Manufacturing. v.10, no.1-4, p.4-16.

GOULART, C.P. (2000). Proposta de um modelo de referência para planejamento e controle da produção em empresas virtuais. São Carlos. 169p. Dissertação (mestrado), Escola de Engenharia de São Carlos, Universidade de São Paulo.

GUPTA, A. (2000). Enterprise resourcing planning: the emerging organizational value system. Industrial Management \& Data Systems. vol.100/3 (2000), p.114-118.

GONG, D.C.; HSIEH, Y.W. (1997). Conceptual Design of a shop floor control information system. International Journal of Computer Integrated Manufacturing. vol10/1-4, p.4-16.

HOPP, W.J.; SPEARMAN, M.L. (2001) Factory Physics: foundations of manufacturing management. New York. Irwin/McGraw-Hill.

HOWELLS, R. (2001). ERP needs shop-floor data. Integrated Manufacturing Solutions. SME. v.1, n.9. 
JUNQUEIRA, G.S; MEIRELES, G.C; MEDALHA, G.C; OLIVEIRA, J.F; BREMER, C.F. (2000). O gerenciamento da cadeia de suprimentos integrado com a supervisão de chão-de-fábrica em indústria mecânicas. In: Congresso e Exposição Internacionais da Tecnologia da Mobilidade, IX, São Paulo, 2000. SAE Technical Paper Series. 2000-01-3243 P.

IPROS - INTEGRATED PRODUCTION AND SUPPLY CHAIN MANAGEMENT (1999) - Conjunto de Pesquisadores do NUMA - USP. São Carlos.

ISA - INSTRUMENT SOCIETY OF AMERICA (2000). Enterprise-Control System Integration, Part 1: Models and Terminology. (Draft Standard).

KAPLAN, R.S.; NORTON, D.P. (1997). A estratégia em ação: balanced scorecard. Rio de Janeiro. Campus.

LAKATOS, E.M.; MARCONI, M.A. (1983). Metodologia Científica. São Paulo, Atlas.

LAURINDO, F.; MESQUITA, M.A. (2000). Materials Requirement Planning: 25 anos de história - Uma revisão do passado e prospecção do futuro. Gestão \& Produção. v7-3, p.320-337.

LEFRANÇOIS, P.; CLOUTIER, L.; MONTREUIL, B. (1996). An agent-driven approach to design factory information systems. Computers in Industry. v.32, p.197217.

LINDAU, R.A. (1997). Automatic data capture and its impact on productivity. International Journal of Production Economics, v.52, p.91-103.

LUMMUS, R.R.; VOKURKA, R.J.; ALBER, K.L. (1998). Strategic supply chain planning. Production and Inventory Management Journal, v.39, n.3, p.49-58, APICS. 
MAGLICA, R. (1997). Improving the PAC shop-floor control architecture to better support implementation. Computers in Industry, v.33, p.317-322.

MARKS, E., SCORZA, P., (1997), MES - O Quê e Por Quê, www.atan.com.br (12/01/2000).

MARTINS, R.A. (1998). Sistemas de medição de desempenho. Tese (Doutorado). São Paulo. Escola Politécnica - Universidade de São Paulo.

McKAY, K. N.; BUZACOTT (2000). The application of computerized production control systems in job shop environments. Computers in Industry, v.42, p.79-97.

MEIRELES, G. S. (2000), Desenvolvimento de sistema de aquisição de dados em operações de usinagem visando o monitoramento de linhas ou células de produção, São Carlos. 119p. Dissertação (mestrado), Escola de Engenharia de São Carlos, Universidade de São Paulo.

MELLO, R.G. (2000). Desenvolvimento de Sistemas de Manufatura para Empresas de Usingem. Texto para Qualificação (Mestrado). São Carlos. Escola de Engenharia de São Carlos - Universidade de São Paulo.

MESA. (1997a). The Benefits of MES: A Report from the Field. (International White Papers, n. 1).

MESA. (1997b). MRP to MES: Data Flow Possibilities. (International White Papers, n. 2)

MESA. (1997c). MES Explained, A hight level view. (International White Papers, n. 6). 
NAGENDRA, P.B.; DAS, S.K. (1999). MRP/sfx: a kanban-oriented shop floor extension to MRP. Production Planning \& Control. v.10/3. p.207-218.

NúCLEO DE MANUFATURA AVANÇADA (2002). Sistemas ERP. htpp://www.numa.org.br/conhecimentos/conhecimentos_port/pag_conhec/ERP_v2. html. (12/04/2002).

PIRES, S. R. I. (1995), Gestão Estratégica da Produção. Piracicaba. Editora UNIMEP, 269p.

PIRES, S. R. I. (1998), Gestão da cadeia de suprimentos e o modelo do consórcio modular. Revista de Administração, v.33, n.3, p5-15.

PORTER, K.; LITTLE, D.; PECK, M.; ROLLINS, R. (1999). Manufacturing classifications: relationships with production control systems. Integrated Manufacturing Systems, v.10/4, p.189-198.

ROWEN, R.B. (1999). A Manufacturing engineer's introduction to supply chain management (Blue Book Series). Deaborn, Computer and Automated Systems Association of the Society of Manufacturing Engineers.

ROZENFELD, H. (1996). Reflexões sobre a manufatura integrada por computador. In: Workshop Manufatura Classe Mundial. São Paulo. 1996. Mitos \& Realidade. São Paulo. EPUSP. p.25-38.

SILVA, E.L.; MENEZES, E.M. (2000). Metodologia da pesquisa e elaboração de dissertação. Florianópolis. Laboratório de Ensino a Distância - Universidade Federal de Santa Catarina. 118p.

SOUZA, F.B. (1997). Fundamentos da teoria da restrições e uma aplicação em uma metodologia de integração de empresas. São Carlos. 206p. Dissertação (Mestrado), Escola de Engenharia de São Carlos, Universidade de São Paulo. 
SLACK, N.; CHAMBERS, S.; HARLAND, C.; HARRISON, A.; JOHNSTON,R. (1999). Administração da Produção (edição compacta). São Paulo. Editora Atlas.

SUZAKI, K. (1993). The new shop floor management: empowring people for continuous improvement. New York. The Free Press

SZELKE, E.; MÁRKUS, G. (1994). Contigency and performance-driven reactive scheduling in discrete event. In: IFIP WG5.7 Working Conference on Evaluation of Production Management Methods. Gramado (1994). Proceedings. North-Holland.

TATSIOPOULOS, I.P. (1997). An Orders Release reference model as a link between production management and shop floor control software. Computers in Industry, v.33, p.335-344.

TSUBONE, H.; KUROYA, T.; MATSUURA, H. (1999). The impact of order release strategies on the manufacturing performance for shop floor control. Production Planning and Control, v.10, no.1, p.58-66.

UNIVERSIDADE DE SÃO PAULO. Escola de Engenharia de São Carlos. Serviço de Biblioteca (1996). Diretrizes para elaboração de dissertações e teses na EESC-USP. São Carlos, $2^{\circ}$.ed.

VAN BRUSSEL, H.; BONGAERTS, L.; WYNS, J.; VALCKENAERS, P.; VAN GINDERACHTER, T. (1999). A conceptual framework for holonic manufacturing: identification of manufacturing holons. Journal of Manufacturing Systems. v.18/1. p.35-52.

VOLLMANN, T.E.; BERRY, W.L.; WHYBARK, D.C. (1997). Manufacturing Planning and Control Systems, $4^{\text {th }}$ ed, New York, Irwin/McGraw-Hill.

WOMACK, J.P.; JONES, D.T. (1998). A mentalidade enxuta nas empresas: elimine o desperdício. Rio de Janeiro. Campus. 
WORTMANN, J.C. (1998). Evolution of ERP systems. In: The International Conference of the Manufacturing Value-Chain (1998), Troon - UK. Proceedings: Troon, Kluwer, p.11-24.

ZHANG, J.; CHUAH, B.; CHEUNG, E.; ZI, D. (1996). Information modeling for manufacturing systems: a case study. Robotics \& Computer Integrated Manufacturing. v.12/3. p.217-225. 